\title{
A CHRONOLOGICAL LIST OF REFERENCES ON SWITCHED CAPACITOR NETWORKS AND TECHNIQUES FOR THE PERIOD 1981-1992
}

\author{
A.K. SINGH \\ Electronics Lab., Department of Electronics and Communication Engineering, Delhi Institute of \\ Technology, Kashmere Gate, Delhi 110006, India.
}

(Received November 16, 1993; in final form December 15, 1993)

A chronological list of 440 references on switched capacitor (SC) networks from 1939 to May 1981 was published in this Journal by J. Vandewalle. In this communication, we present a compilation of 1357 references covering the period from May 1981-1992 (along with a supplementary list of 43 missing references for the period before May 1981). The present compilation and the earlier one by Vandewalle put together, thus, constitute an exhaustive bibliography of 1797 references on SC-networks and techniques till 1992.

\section{INTRODUCTION}

The importance of SC-networks in the area of instrumentation and communication is well established. Because of their suitability to VLSI implementation, along with digital networks on the same chip and their low cost coupled with accuracy, SCnetworks have greatly enhanced their applicability in the electronics world. Enormous volumes of literature on the SC-techniques for different applications is now available. Many design procedures including those based upon immittance simulation and wave concepts have been evolved. Application of SC-networks in the design of FIR and IIR filters and neural networks have also been reported. Moreover, many computer-aided techniques have been developed to perform the frequency response analysis, noise analysis and sensitivity analysis. Peculiar effects, such as effects of aliasing, parasitic stray capacitances, offsets, drifts, op-amp poles, finite switch resistances, and nonlinearities, have also been studied. Many more new applications of these networks are at threshold.

As a bibliography of work done in SC-networks to May, 1981 already exists [84], a compilation of the works done in this area after the period May 1981 is of significant interest in order to have a comprehensive collection of references from 1939 through 1992.

The present compilation is based upon the literature available in Journals, books, tutorial reviews, and conferences, and is arranged in order of their dates of publication. 
An attempt has been made to classify the various contributions into eight categories. The classes to which a work belongs, has been indicated within braces at the end of each reference. The various categories are as follows:

(A) Analysis, Synthesis, and Design: This class covers the contributions dealing with the mathematical techniques for analysis (including computer-aided analysis), synthesis, and design techniques (including those based upon wave concepts and signal flow graphs) of SC-networks and their hardware implementations. Also included are papers dealing with sensitivity analysis, noise analysis, and approaches to obtain stray insensitive realizations.

(B) Amplification: This class is concerned with SC-amplifiers and their applications; different types of integrators, differentiators, and techniques for measurement of their parameters.

(C) Oscillators: Publications belonging to this class deal with various types of oscillators, ultra high frequency oscillators, and voltage controlled oscillators.

(D) Filters: This category includes different types of passive and active SC-filters (including biquads), and their improved versions; analysis of canonic, programmable, wave SC filters; design of filters using other active elements such as Current Conveyors and design of filters for SC-phase locked loops and other related ideas.

(E) Digital filters: This class covers the design of SC-based FIR, IIR, and digitally programmable filters.

(F) Immittance Simulation: This category includes circuits for simulating inductance and various other types of elements such as FDNR, and FDNC, etc. Realizations of gyrators and immittance converters are also covered here.

(G) Converters: Publications belonging to this class deal with various types of converters such as $\mathrm{A} / \mathrm{D}, \mathrm{D} / \mathrm{A}, \mathrm{DC} / \mathrm{AC}, \mathrm{AC} / \mathrm{DC}$, and $\mathrm{DC} / \mathrm{DC}$.

(H) General: This class includes references of Bibliographies, and Books published on SC-networks.

\section{BIBLIOGRAPHY}

1981

[1] B. Anjaiah and A. Prabhakar, "On the synthesis of switched capacitor filters," J. Inst Electron \& Telecommuni. Engg. vol. 27, no. 5, pp. 16-5, May 1981. (D)

[2] S.M. Bozic, "A comparison of switched capacitor networks analysis," Int. J. Electron., vol. 50, no. 1, pp. 37-45, May 1981. (A)

[3] G. Martinelli and M. Salerno, "Passive SC low pass filters," Altra. Freq. vol. 50, no. 3, pp. 160-4, May 1981. (D)

[4] F. Krummenacher, E. Vittoz and M. Deganwe, "Class AB CMOS amplifier for micro power SC filters," Electron. Lett. vol. 17, no. 13, pp. 433-5, May 1981. (D)

[5] J. Mikula, "Analysis of circuits with switched capacitors," Slaboproudy Obz, vol. 42 , no. 6 , pp. 297-7, June 1981. (A)

[6] K. Martin, "Switched capacitor building blocks for adaptive systems," IEEE Trans. Circuits \& Syst., vol. 28, no. 6, pp. 576-84, June 1981. (A) 
[7] R.L. Geiger, and P.E. Allen, "Switched resistor filter," 24th Midwest Symp. on circuits and systems, Albuquerque, New Mexico, pp. 87-91, June 1981. (D)

[8] W.B. Mikhael and S. Tu, "Programmable multilevel frequency shift keying using switched capacitor techniques," 24th Midwest Symp. on circuits and systems, Albuquerque, New Mexico, pp. 445-3, June 1981. (H)

[9] J. Pandel, "Design and analysis of switched capacitor filter using recharging devices," 24th Midwest Symp. on circuits \& systems, Albuquerque, New Mexico, pp. 454-8, June 1981. (D)

[10] M.S. Lee, "Minimization of DC offset voltage in SC filter," 24th Midwest Symp. on circuits and systems, Albuquerque, New Mexico pp. 459-62, June 1981. (D)

[11] H.C. Patangia and J. Cartinhour, "A tunable switched capacitor N-path filter," 24th Midwest Symp. on circuits and systems, Albuquerque, New Mexico, pp. 404-4, June 1981: (D)

[12] M.B. Ghaderi and G.C. Temes, "Linear interpolation using CCD or switched capacitor filters," 24th Midwest Symp. on circuits and systems, Albuquerque, New Mexico, pp. 449-53, June 1981. (D)

[13] D. Herbst, A. Fettweis, B. Hoefflinger, U. Kleine, W. Nientiedt, J. Pandel and R. Schweer, "An integrated seventh order unit element filter in VIS-SC technique," IEEE J. solid state circuits, vol. 16, no. 3, pp. 140-146, June 1981. (D)

[14] C.F. Lee and W.K. Jenkins, "Computer-aided analysis of switched capacitor filters," IEEE Trans Circuits \& Systems, vol. 28, no. 7, pp. 681-92, July 1981. (D)

[15] M. Yamamoto, M. Tanaka, T. Yaguchi, and S. Mori, "Large time constant switched capacitor circuits constructed by small capacitor ratio," Trans. Inst. Electron. \& communi. Engg. Jpn. Sect. E, vol. 64, no. 8, pp. 556, July 1981.

[16] G.H.S. Rokos, "Comment on voltage amplification in switched capacitor networks." Electron. Lett. vol. 17, no. 14, pp. 501, July 1981. (B)

[17] J.J. Mulawka, "Synthesis of single amplifier switched capacitor networks," Electron. Lett., vol. 17, no. 14, pp. 510-12, July 1981. (A)

[18] J. Pandel and D. Herbst, "VIS-SC filters for higher frequency application," Electron. Lett., vol. 17, no. 14, pp. 504-6, July 1981. (D)

[19] F. Ueno, T. Inoue and T. Uchikura, "A new bilinear switched capacitor floating LC parallel circuit and its analysis," Trans. Inst. Electron. \& Communi. Engg. Sect. E., vol E69, no. 8, pp. 558, July 1981. (A)

[20] E. Sanchez-Sinencio, J. Silva-Martinez and R. Alba-flores, "Effect of finite op-amp gain bandwidth product on switched capacitor amplifier," Electron. Lett. vol. 17, no. 14 , pp. 509-10, July 1981. (B)

[21] S.M. Faruque, J. Vlach and T.R. Viswanathan, "Switched capacitor inductors and their use in LC filter simulation," IEEE Proc., vol. 128, no. 4, pp. 227-9, August 1981. (F)

[22] K. Haug, "Design, analysis and optimization of switched capacitor filters derived from lumped analog model," AEU, vol. 3, no. 7-8, pp. 279-89 August 1981. (D)

[23] J.J. Mulawka, "Switched capacitor implementation of analogue sampled data recursive filters," Int. J. Electron. vol. 51, no. 2, pp. 173-80, August 1981. (D) 
[24] U.W. Brugger, D.C. Von. Gruenigen, and G.S. Moschytz, "A compressive procedure of the design of cascaded switched capacitor filters," IEEE Trans. Circuits \& System vol. 28, no. 28, pp. 803-10, August 1981. (D)

[25] K. Martin and A.S. Sedra, "Effects of the op amp finite gain and bandwidth on the performance of switched capacitor filter," IEEE Trans Circuits \& Systems, vol. 28, no. 28, pp. 822-9, August 1981. (D)

[26] U. Kleine, D. Herbst, B. Hoeffinear, B.J. Hosticka and R. Schweer, "Real time programmable unit element SC filter for LPC synthesis," Electron. Lett., vol. 17, no. 17, pp. 600-602 August 1981. (D)

[27] S.C. Fang, Y.P. Tsividis and O. Wing, "SWITCAP, a switched capacitor network analysis program," Proceeding of the European conf. on circuit theory and design, The Hague, Netherlands, pp. 512, August 1981. (D)

[28] S. Eriksson, "An approach to the realization of switched capacitor filter using the bilinear transformation," Proceeding of European conf. on circuit theory and Design, The Hague Netherlands, pp. 803-27, August 1981 (D)

[29] T. Takabe, K. Nishikawa and E. Murata, "Switched capacitor delay equalizer using complex coefficient networks," Proceeding of European conf. on circuit theory and design, The Hague, Netherlands, pp. 798-802, August 1981. (H)

[30] A.S. Sedra, "Design of strays insensitive switched capacitor filters-a review," Proceeding of European conf. on circuit theory and design, The Hauge, Netherlands, pp. 519, August 1981. (H)

[31] G.C. Temes, "Mos switched capacitor filters-History and state of art," Proceeding of the European conf. on circuit theory and design, The Hague, Netherlands, pp. 176-85, August 1981. (D)

[32] D. Herbrt, and B. Hoefflinger, "Master silica switched capacitor filters," Proceeding of the European conf. on circuit theory and design, The Hague, Netherlands, pp. 693, August 1981. (D)

[33] J. Vlach and K. Singal, "Complete methods for linear switched capacitor networks," Proceeding of the European conf. on circuit theory and design, The Hague, Netherlands, pp. 234-42, August 1981. (A)

[34] L.T. Bruton and G. Battacharjee, "Formulation of nodal charge equations of switched capacitor networks containing nullors," Proceeding of the European conf. on circuit theory and design, The Hague, Netherlands, p. 110-17, August 1981 (A)

[35] M. Bon, and A. Konzykowska, "All-symbolic analysis techniques for multi phase switched capacitor networks," Proceeding of the European conf. on circuit theory and design, The Hague, Netherlands, pp. 655-60, August 1981. (A)

[36] J. Pandel, "Design of bottom plate parasitic insensitive switched capacitor filters using recharging devices," Proceeding of the European conf. on circuit theory and design, The Hague, Netherlands, pp. 675-80, August 1981. (D)

[37] S. Eriksson, "Realization of synchronous wave switched capacitor filters," Proceeding of the European conf. on circuit theory and design, The Hague, Netherlands, pp. 650-80, August 1981. (D)

[38] B.B. Battacharyya and R. Raut, "Low sensitivity realization of sampled data filters using unity gain amplifiers and switched capacitors," Proceeding of the 1981 European conf. on circuit theory and design, The Hague, Netherlands, pp. 808-13, August 1981. (D) 
[39] J.A. Nossek, G.J. Smolka and V. Loibl, "Switched capacitor narrow band filters," Proceeding of the 1981 European conf. on circuit theory and design, The Hague, Netherlands, pp. 518 August 1981. (D)

[40] G. Spahlinger, "The influence of operational amplifier in switched capacitor filters," AEU, vol. 35, no. 9, pp. 342-8, August 1981. (D)

[41] J.A. Nossek, G.J. Smolka, D. Herbst and B. Hoeffinger, "Integrated CMOS SC filter based one port simulation," European conf. on solid state circuits, Friburg, Germany, pp. 178-80, Sept. 1981. (D)

[42] H. De. Man, J. Rabacy, L. Claesen, and J. Vandewall, "DIANA-SC a complete CAD system for switched capacitor filter," European Conf. on Solid State Circuits, Friburg, Germany, pp. 130-3, Sept. 1981. (D)

[43] B.J. Hosticka, D. Harbest, B. Hoefflinger, U. Kleine, J. Pandel and R. Schweer, "Real time programmable low power SC band pass filter," European Solid State Circuits Conf. Freibug, Germany. pp. 22-24, Sept. 1981. (D)

[44] F. Krummenacher, "Micropower switched capacitor biquadratic cell," European conf. on solid state circuits. Freiburg, Germany, pp. 175-7, Sept. 1981. $(\mathrm{H})$

[45] P. Gillingham, "Frequency domain analysis of switched capacitor networks using analog two port equivalents," Mitt. Agen., no. 32, pp. 17-24, Oct. 1981. (A)

[46] A. Knob and R. Dessoulavy, "Analysis of switched capacitor networks in the frequency domain using continuous-time two-port equivalent," IEEE Trans, Circuit \& Syst., vol. 24, no. 10, pp. 947-53, Oct. 1981. (A)

[47] R. Plodeck and U.W. Brugger, "Scandal-versal program for computer-aided analysis of SC network," Journees d'electronique 1981, Modern Filtering Technique, Lausanne, Switzerland, pp. 317-37, Oct. 1981. (A)

[48] F. Krummenacher, "Optimization of micro power switched capacitor filters," Journees d'Electronique 1981 Modern Filter Techniques, Lausanne, Switzerland, pp. 283-94, Oct. 1981. (D)

[49] S. Eriksson: " An approach to wave switched capacitor filter implementation," Journees d'Electronique 1981, Modern Filtering Technique, Lausanne, Switzerland, pp. 263-74, Oct. 1981. (D)

[50] B.J. Hosticka, "Introduction to switched capacitor filters," Journees d'Electronique 1981, Modern Filtering Technique, Lausanne, Switzerland, pp. 69-84, Oct. 1981. (D)

[51] G. Martinelli and M. Salerno, "Parasitic insensitive switched capacitor filter derive by the bilinear element modelling," Journees d'Electronique 1981, Modern Filtering technique, Lausanne, Switzerland, pp. 305-16, Oct. 1981. (D)

[52] S. Signell and K. Mossberg, "Parasitic insensitivity state variable switched capacitor filters derive from LC-prototype filters via bilinear transform," Journees d'Electronique 1981, Modern Filtering technique, Lausanne, Switzerland, pp. 295305, Oct. 1981. (D)

[53] P. Lutz, "Real terminations for switched capacitor leapfrog filters," Journees d'Electronique 1981, Modern Filtering technique, Lausanne, Switzerland, pp. 27581, Oct. 1981. (D)

[54] G.S. Moschytz, "A morphological approach to switched capacitor low frequency integrator design," Mitt. Agen., no. 2, pp. 7-16, Oct. 1981. (A) 
[55] D.C. Von Gruenigen, U.W. Brugger, G.S. Moschytz and W. Vollenweider, "Combined switched capacitor FIR N-path filter using grounded capacitors," Electron. Lett., vol. 17, no. 21, pp. 788-90, Oct. 1981. (D)

[56] G.A. Lampropoulos and L.E. Pepard, "Computer-aided design of switched capacitor filters," Int. Electrical, Electronics Conf. and exposition, Toronto, Canada, pp. 50-1, Oct. 1981. (D)

[57] R. Gregorian and S.C. Fan. "Ladder simulation switched capacitor filters with inductor loops," Electron. Lett., vol. 17, no. 21, pp. 786-5, Oct. 1981. (F)

[58] H.M. Reekie, J. Mavor and P.B. Denyer, "Realization of a switched capacitor voltage wave pseudo band pass filter," Electron. Lett., vol. 17, no. 21, pp. 795-6, Oct. 1981. (D)

[59] G.C. Temes and G. Muller, "The poor man's algorithm for SC circuits," fifteenth Asilomar conf. on circuits, system and computers, Pacific Grove, pp. 4938, Nov. 1981. (A)

[60] Yun Sun and R.Y. Wong, "Tunable positive gain RC and SC active notch filters," fifteenth Asilomar conf. on circuits, system and computers, Pacific Grove, pp. 290-2, Nov. 1981. (D)

[61] R. Gregorian and R. Shin Chung, "Inductor loops in ladder simulation switched capacitor filters," fifteenth Asilomar conf. on circuits, system and computers, Pacific Grove, pp. 281-4, Nov. 1981. (F)

[62] Yun Sun and R.Y. Wong, "Tunable positive gain RC and SC active notch filters," fifteenth Asilomar conf. on circuits, system and computers, Pacific Grove, pp. 290-2, Nov. 1981. (D)

[63] R. Gregorian and R. Shin Chung, "Inductor loops in ladder simulation switched capacitor filters," fifteenth Asilomar conf. on circuits, system and computers, Pacific Grove, pp. 281-4, Nov. 1981. (F)

[64] J. Pandel and J. Dawein, "Novel realization of floating voltage inverter switches and inductance for SC filters," fifteenth Asilomar conf. on circuits, system and computers, Pacific Grove, pp. 293-7, Nov. 1981. (G)

[65] N. Attaie and E. I.EI-Masry, "A low sensitivity multiple loop feedback SC structure," fifteenth Asilomar conf. on circuits, system and computers, Pacific Grove, pp. 285-9, Nov. 1981. (A)

[66] J. Silva-Martinez and E. Sanchez-Sinencio, "Simple SC circuits as affected by the op amp gain bandwidth product," fifteenth Asilomar conf. on circuits, system and computers, Pacific Grove, pp. 298-302, Nov. 1981. (A)

[67] S.S. Viglione, "Low cost voice recognition system," Midcon.81 Conf. Record, Chicago, Elsegundo, CA, USA, Electron. Conventions, pp. 6/1-1, Nov. 1981. (H)

[68] B. Furer and W. Guggenbuhl, "Noise analysis of sampled-data circuit," AEU, vol. 35, no. 11, pp. 426-31, Nov. 1981. (A)

[69] P.E. Fleicher, A. Ganesan and K.R. Laker, "Parasitic compensated switched capacitor circuit," Electron. Lett., vol. 17, no. 24, pp. 929-31, Nov. 1981. (A)

[70] H. Jamal and F.E. Holmes, "MOS switched capacitor integrator eliminating op. amp.," Electron. Lett., vol. 17 no. 24, pp. 925-6, Nov. 1981. (B) 
[71] Hsich Kuo chiang, P.R. Gray, D. Senderowica and D.G. Messerschmitt, "A Low-noise chopper-stabilized differential switched capacitor filtering technique," IEEE J. Solid State Circuits, vol. 16, no. 6, pp. 708-15, Dec. 1981. (D)

[72] J. Mavor, H.M. Reekie and P.B. Denyer, "A prototype switched capacitor voltage wave filter realized in NMOS technology," IEEE J. Solid State Circuits, vol. 16, no. 6, pp. 716-23, Dec. 1981. (D)

[73] D.J. Allstot and Tan Khen Sang, "Simplified MOS switched capacitor ladder filter structure," IEEE J. Solid State Circuits, vol. 16, no. 6, pp. 724-9, Dec. 1981. (D)

[74] R. Plodeck, U.W. Brugger, D.C. Von Grunigen and G.S. Moschytz, "SCANAL, a program for computer-aided analysis of switched capacitor networks," IEE Proc. G, vol. 17, no. 24, pp. 929-31, Dec. 1981. (A)

[75] G.S. Moschytz, "Simplified analysis of switched capacitor networks," Electron. Lett., vol. 17, no. 25, pp. 975-7, Dec. 1981. (A)

[76] G.C. Temes and G. Muller, "A paupeer's algorithm for switched capacitor circuit analysis," Electron. Lett., vol. 17, no. 25, pp. 942-4, Dec. 1981. (A)

[77] T. Takabe, "Switched capacitor filters," J. Inst. Electron. \& Communi. Engg. Jpn., vol. 64, no. 12, pp. 1293-300, Dec. 1981. (D)

[78] H.M. Reekie, J. Mavor and P.B. Denye, "Realization of a switched capacitor voltage wave pseudo band pass filter," Electron. Lett., vol. 17, no. 21, pp. 795-6, Dec. 1981. (D)

1982

[79] F. Ueno, T. Inoue and I. Oota, "Realization of closely coupled inductors using switched capacitor," IEEE Trans. Circuits \& Syst. vol. 29, no. 1, pp. 52-3, Jan. 1982. (F)

[80] J. Lippmann, "Frequency response analysis of switched capacitor filter having several switching," Nachrichten. Elektronik., vol. 32, no. 2, pp. 69-72, 1982. (D)

[81] B. Mossner, "Design of low frequency switched capacitor band pass filter," Nachrichten. Elektronik., vol. 32, no. 02, pp. 77-80, 1982. (D)

[82] E. Vittoz, "Microwatt switched capacitor circuit design," Electrocomp. Sci. \& Technol., vol. 9, no. 4, pp. 263-73, 1982. (A)

[83] J. Lippmann, "Fast analysis method for SC integrator filters with two switching stage," Nachrichten. Electronik, vol. 32, no. 11, pp. 454-457, 1982. (D)

[84] J. Vandewalle, "A chronological list of references on switched capacitor circuits," Electrocomp. Sci. \& Technol., vol. 9, no. 4, pp. 275-88, 1982. (H)

[85] N. Hirt and J. Szopa, "Design of switched capacitor networks with the aid of normalized mason graph," Nachrichten. Electronik, vol. 32, no. 10, pp. 431-5, 1982. (A)

[86] H. Kunieda, "Adjoint network approach to sensitivity calculation for SC networks," Trans. Inst. Electron. \& Communi. Engg. Jpn. Sect. E, vol. E65, no. 1, pp. 74, Jan. 1982. (A)

[87] J.J. Mulawka and A. Konczykowska, "Simulation of switched-capacitor on a small minicomputer," Arch. Electrotech., vol. 31, no. 2, pp. 222-30, 1982. (A) 
[88] R.L. Geiger, and P.E. Allen, "Switched resistor filters-continuous time approach to monolithic MOS filter design," IEEE Trans Circuits. \& Syst., vol. 29, no. 5, pp. 2046, Jan. 1982. (D)

[89] W. Wandnga and I. Heiden, "Realization of low pass filters with cauer characteristic using cascaded SC filters," Nachrichten. Electron. vol. 32, no. 5, p. 204-6, 1982. (D)

[90] K. Martin, "New Clock feed through cancellation technique for analogue MOS switched capacitor circuits," Electron. Lett., vol. 18, no. 1, pp. -39-40, Jan. 1982. (A)

[91] P.V. Anand Mohan, M.N.S. Swamy and V. Ramchandran, "General strayinsensitive first order active SC network," Electronic. Lett., vol. 18, no. 1, pp. 12 Jan. 1982.

[92] K. Watanable and G.C. Temes, "Switched capacitor digital multiplier," Electron. Lett., Vol. 19, no. 2, pp. 33-6, Jan. 1982. (E)

[93] U. Kleine and J. Pandel, "Novel analysis of N-path switched capacitor pseudo filter," Electronic. Lett., vol. 18, no. 02, pp. 66-8, Jan. 1982. (D)

[94] M. Tanaka and S. Mori. "Topological formulation for the coefficient matrices of state equation for switched capacitor networks," IEEE Trans Circuits \& Syst., vol. 29, no. 2, pp. 106-15, Feb. 1982. (A)

[95] R.L. Geiger and E. Sanchez-Sinencio, "Operational amplifier gain bandwidth product effects on the performance of switched capacitor networks," IEEE Trans Circuits \& Syst., vol. 29, no. 2, pp. 96-106, Feb. 1982. (B)

[96] E. Luderr and G. Spahlinger, "Performance of various types of switched capacitor filter," Arch. Electr. \& Ubetr., vol. 36, no. 2, pp. 57-62, Feb. 1982. (D)

[97] S. Ueno, Y. Ikeda and S. Takahashi, "Synthesis of wide band SC filter based on approximation theory," Trans. Inst. Electron. \& Communi. Eng. Jpn. Sect. E., vol. E365, no. 5, pp. 130. Feb. 1982. (D)

[98] P. Lambrecht, "SC filter module," Electron. Appl., vol. 14, no. 3, pp. 502, March 1982. (D)

[99] R. Raschke, "Analysis of switched capacitor filters with parasitic element based upon the voltage inversion," AEU, vol. 36, no. 3, pp. 119-23, March 1982. (D)

[100] S. Nishimura and S. Fujii, "Block extraction approach to realization of switched capacitor filters," Mem. Fac. Eng. Kobe. Univ., no. 28, pp. 273-83, March 1982. (D)

[101] C.J. Wellelen, "Equivalent of two design of SC ladder filters," Electron. Lett., vol. 18, no. 6, pp. 246-7, March. 1982 (D)

[102] E. Hokenet, U.W. Brugger and G.S. Moschytz, "New frequency transformation for the accurate design of SC filters," Electron. Lett., vol. 18, no. 6, pp. 276-8, March 1982. (D)

[103] G. Martinelli and M. Salerno, "Parasitic insensitive SC filters derived by the bilinear element modelling," Altra. Frequency, vol. 51, no. 2, pp. 64-70, March 1982. (D)

[104] W. L. McCall, S. M. Raid, F. M. Stepheson and A. A. Riad, "Computer modelling of switched capacitor filters," Proc. of the Fourteenth Southeastern symp. on system theory, Blackburg, pp. 110-13, April 1982. (D) 
[105] R.D. Davis, "A derivation of the switched-capacitor adjoint network based on modified Tellegen's theorem," IEEE Trans. Circuits \& Syst., vol. 29, no. 4, pp. 215-20, April 1982. (A)

[106] M.L. Dragoman and I. Ardelean, "Switched capacitor filters implementation," Bull Inst. Polieh Gheorghe Gheroghia-Dej Bucuresti Ser. Electrotech., vol. 44, no. 2, pp. 53-60. April 1982. (D)

[107] B. Huber, R. Lucker, A.H.M. Van Roermond and P.M.C. Coppelmans, "Design of a SC filter for view data modems," AEU, vol. 36, no. 4, pp. 141-7, April 1982. (D)

[108] L.T. Bruton and G. Bhattacharjee, "Formulation of nodal equations of switched capacitor network containing nullors." Can. Electr. Engg. J, vol. 7, no. 2, pp. 21-7, April 1982. (A)

[109] S.M. Faruque, "SC FIR cell for N-path filters," Electron. Lett., vol. 10, no. 10 , pp. 431-21, April 1982. (E)

[110] H. Baher and S.O. Scanlan, "Stability of exact synthesis of low pass switched capacitor filters," 1982 Int. symp on circuits and systems, Rome, pp. 14, vol. 1, May 1982. (D)

[111] K.R. Laker, P.E. Fleicher and A. Ganesan, "Parasitic insensitive bi-phase switched capacitor filters realized with one op amp. per mode pair," 1982 Int. symp on circuits and systems, Rome, pp. 435-9, vol. 2, May 1982 (D)

[112] L.T. Bruton, G.R. Bailey and G. Battacharjee, "Loop equation formulation for switched capacitor networks containing nullor," 1982 Int. symp on circuits and systems, Rome, pp. 29-31, vol. 1, May 1981. (A)

[113] F. Anday, "Realization of Norton amplifier SC networks," 1982 Int. symp on circuits and systems, Rome, pp. 245-7, vol. 2, May 1982. (A)

[114] E.P. Rudd and R. Schauman, "An analysis of program for SC filters including the effects of op. amp. bandwidth \& switch resistance," 1982 Int. symp on circuits and systems, Rome, pp. 13-16, vol. 1, May 1982 (D)

[115] K. Matsui, T. Matsura and K. Iwasaki, "Micro CMOS switched capacitor circuits for analog video LSI", 1982 Int. symp. on circuits and systems, Rome, pp. 241-242, vol. 2, May 1982. (H)

[116] F. Brglez, "An efficient computer aided analysis of very large switched capacitor networks," 1982 Int. symp. on circuits and systems, Rome, pp. 9-12, vol. 1, May 1982 (A)

[117] H. Weinrichter, "Equivalent noise source of switched capacitor networks elements," 1982 Int. symp. on circuits and systems, Rome, pp. 38-41, vol. 1, May 1982. (H)

[118] T. Fjallbrant, "Analysis and design of discrete time networks with sub multiple, delay, switched capacitor filter applications," 1982 Int. symp. on circuits and systems, Rome, pp. 21-4, vol. 1, May 1982. (D)

[119] N. Attaie and E.I. EI-Masry, "A low sensitivity switched capacitor structure," 1982 Int. symp. on circuits and systems, Rome, pp. 55-9, vol. 2, May 1982. (H)

[120] J. Vandewalle, H. De. Man, J. Rabacy and L. Claesen, "A pictorial derivation of the signal processing mechanism of multi phase switched capacitor networks," 1982 Int. symp. on circuits and systems, Rome, pp. 25-8, vol. 1, May 1982. (H) 
[121] E. Wehrhahn, "Transfer function of periodically switched linear networks with S-H at the input and output ports," 1982 Int. symp. on circuits and systems, Rome, pp. 427-30, vol. 1, May 1982. (A)

[122] I. Kawakami and T. Komazaki, "On the switched capacitor equalizer," 1982 Int. symp. on circuits and systems, Rome, pp. 237-40, vol. 2, May 1982 (H)

[123] P.V. Anand Mohan, V. Ramachandran and M.N.S. Swami, "Passive and active switched capacitor networks," 1982 Int. symp on circuits and systems, Rome, May 1982. (A)

[124] K. Martin, "A switched capacitor realization of a spectral line enhance," 1982 Int. symp. on circuits and systems, Rome, pp. 229-32, vol. 2, May 1982. (H)

[125] K. Kato and T. Takabe, "High-Q switched capacitor all pass networks with low sensitivity," 1982 Int. symp. on circuits and systems, Rome, pp. 442-50, vol. 2, May 1982. (D)

[126] E. Hokenek, U.W. Brugger and G.S. Moschytz, "Design of multiplexed switched capacitor filters," 1982 Int. symp. on circuits and systems. Rome, pp. 213-16, vol. 2, May 1982. (D)

[127] E. Sanchez-Sinencio, "Minimization of gain bandwidth product effects in switched capacitor filters," 1982 Int. symp. on circuits and systems, Rome, pp. 468-71, vol. 2, May 1982. (D)

[128] A. Libertore and S. Moneti, "On the synthesis of passive switched capacitor low pass filters," 1982 Int. symp. on circuits and systems, Rome, pp. 737-40, vol. 3, May 1982. (D)

[129] B. Furrer and W. Guggenbuhl, "Noise analysis of a SC biquad," 1982 Int. symp. on circuits and systems, Rome, pp. 460-3, vol. 2, May 1982. (D)

[130] T.R. Viswanathan, "FDNR switched capacitor filters insensitive to parasitic capacitors," 1982 Int. symp. on circuits and systems, Rome, pp. 440-2, vol. 2, May 1982. (D)

[131] A. Dabrowski, "Improved zero phase lag integrators with grounded switched capacitors," 1982 Int, 1982 Int. symp. on circuits and systems, Rome, pp. 753-5, vol. 3, May 1982. (B)

[132] J. Vlach, K. Singhal and M. Vlach, "Analysis of switched capacitor networks," 1982 Int. symp. on circuits and systems, Rome, pp. 9-12, vol. 1, May 1982. (A)

[133] J.J. Mulawka, "Synthesis of switched capacitor biquadratic sections using graphs," 1982 Int. symp. on circuits and systems, Rome, pp. 45-8, vol. 3, May 1982. (A)

[134] G. Spahlinger, "Nonideal op amp in reverse switched capacitor networks," 1982 Int. symp. on circuits and systems, Rome, pp. 55-9, vol. 2, May 1982. (A)

[135] W.B. Mikhael and S. Tu, "A mixed LDI bilinear transformation for biquadratic switched capacitor filters," 1982 Int. symp. on circuits and systems, Rome, pp. 741-4, vol. 3, May 1982. (D)

[136] D.C. Von Gruenigen, U.W. Brugger and G.S. Moschytz, "Switched capacitor frequency sampling N-path filter," 1982 Int. symp. on circuits and systems, Rome. pp. 209-12, vol. 2, May 1982. (D)

[137] R.D. Davis and T.N. Trick, "An efficient LU factorisation scheme for analysis of switched capacitor filters," 1982 Int. symp. on circuits and systems, Rome, pp. 33-7, vol. 1, May 1982. (D) 
[138] N.J. Cutland, C. Lau and J.I. Sewell, "General computer analysis of switched capacitor networks including nonideal amplifiers," 1982 Int. Symp. on circuits and systems, Rome, pp. 17-21, vol. 1, May 1982. (A)

[139] B. Dasch, "Equivalence transformation of SC networks and of microstrip," 1982 Int. Symp. on circuits and systems, Rome, pp. 217-20, vol. 2, May 1982. (H)

[140] S. Eriksson, "Design of parasitic insensitive bilinear switched capacitor filters-a flow graph conversion method," 1982 Int. Symp. on circuits and systems, Rome, pp. 443-6, vol. 2, May 1982.

[141] H. Jamal and F.E. Holmes, "Switched capacitor filters eliminating op amp," 1982 Int. symp. on circuits and systems, Rome pp. 741-4, vol. 3, May 1982.

[142] B.J. Hosticka, W. Brocherds, V. Kleine and R. Schweer, "Nonlinear analog switched capacitor circuits," 1982 Int. symp. on circuits and systems, Rome, pp. 729-32, vol. 3, May 1982. (A)

[143] H. Baher and S.O. Scanlan, "Stability and exact synthesis of low pass SC filters." 1982 Int. symp. on circuits and systems, Rome, pp. 725-7, vol. 3, May 1982. (D)

[144] H. Kunieda, "Effect of finite gain bandwidth products of op amp. on switched capacitor networks approach via equivalent representations," 1982 Int. symp. on circuits and systems, Rome, pp. 464-7, vol. 2, May 1982. (B)

[145] J. Pandel, "Principles of pseudo N-path SC filters using recharging device," AEU, vol. 36, no. 5, pp. 177-87, May 1982. (D)

[146] M. Ishikawa, "Switched capacitor simulation of a floating LC parallel circuit," Trans. Inst. Electron. Communi. Engg. Jpn. Sect. E, vol. E65, no. 5, pp. 288, May 1982. (F)

[147] K.R. Laker, P.E. Fleischer and A. Ganesan, "Parasitic insensitive, biphase switched capacitors realized with one op amp per pole pair," Bell System Tech. J, vol. 61, no. 5 pp 685-708, June 1982. (B)

[148] P.V. Anand Mohan, V. Ramachandran and M.N.S. Swami, "Parasitic compensated second order switched capacitor filters," Electron. Lett., vol. 18, no. 12, pp. 531-3, June 1982: (D)

[149] F. Krummenacher, "Micro power switched capacitor biquadratic cell," IEEE J. Solid State Circuits, vol. 17, no. 3, pp. 501-12 June 1982. (D)

[150] B.J. Hosticka, D. Herbst, B. Hofflinger, U. Kalein, J. Pandel and R. Schweer, "Real time programmable low power SC band pass filter," IEEE Solid State Circuits, vol. 17, no. 3, pp. 506. June 1982. (D)

[151] T. Regan, "Switched capacitor ICs improved filters special case design," EDN, no. 13, pp. 183-91, June 1982. (D)

[152] M. Yamamoto, M. Tanaka and S. Mori, "Multi phase clock switched capacitor circuit by low frequency op-amp," Trans. Inst. Electron. \& Communi. Engg. Sect. E, vol. 65, no. 7, pp. 416, July 1982. (A)

[153] J. Mikula, "Synthesizing elements with switched capacitors," Slaboproudy. Obz, vol. 43, no. 7, pp. 319-23, July 1982. (A)

[154] R.L. Maddox, "Fabrication process techniques for switched capacitor filter circuits," Microelectron. J, vol. 13, no. 4, pp. 29-36, July 1982. (D)

[155] T. Inoue and F. Ueno, "Analysis and synthesis of switched capacitor circuits using switched capacitor immittance converters," IEEE Trans Circuits \& Syst., vol. 29 , no. 7, pp. 488-92, July 1982 . (F) 
[156] R. Gregorian, "An offset free switched capacitor biquads," Microelectron. J, vol. 13 , no. 4, pp. 37-40, July 1982. (D)

[157] F. Maloberti and F. Montecchi, "Low Frequency noise reduction in SC ladder filters," Electron. Lett., vol. 18, no. 15, pp. 675-6. July 1982. (D)

[158] M.B. Ghaderi, J.A. Nossek and G.C. Temes, "Narrow band switched capacitor band pass filter," IEEE Trans Circuits \& Syst., vol. 29, no. 8, pp. 55772, August 1982. (D)

[159] K. Kunida and M. Kaneko, "Equivalent representation for switched capacitor networks and its application," Trans. Inst. Electron. \& Communi. Engg. Sect. E vol. 65, no. 8, pp. 503, August 1982. (A)

[160] J.H. Fischer, "Noise sources and calculation techniques for SC filters," IEEE J. Solid State Circuits, vol. 17, no. 4, pp. 742-52, August 1982. (D)

[161] T.R. Viswanathan, "Switched capacitor frequency control loops (digital transducer)," IEEE J. Solid State Circuits, vol. 17, no. 4, pp. 742-52, August 1982. (H)

[162] Y.P. Tsividis and S.C. Fang, "Simple method for obtaining the equation of switched capacitor circuits," Electron. Lett., vol. 10, no. 17, pp. 734-5, August 1982. (A)

[163] J.C.M. Bermudez and B.B. Bhattacharyya, "Parasitic insensitive toggle switched capacitor and its application to switched capacitor networks," Electron. Lett., vol. 18, no. 17, pp. 735-6, August 1982 (A)

[164] B. Donnelly, "Switched capacitor array semi-custom filter design," Electron. Lett., vol. 9, no. 7, pp. 11-13, August 1982. (D)

[165] H.C. Patangia and J. Cartinhour, "A switched capacitor comb filter using N-path filters," 25th Midwest symp. on circuits and systems, Houghton, pp. 4448, August 1982. (D)

[166] R. Gregorian and D. Parikh, "Effect of DC offset on digital filter implemented in switched-capacitor technology," 25th Midwest symp. on circuits and systems, Houghton, pp. 492-53, August 1982. (E)

[167] P.V. Anand Mohan, V. Ramchandran and M.N.S. Swami, "Multiple feedback biquadratic switched capacitor filter," 25th Midwest symp. on circuits and systems, Houghton, pp. 435-9, August 1982. (D)

[168] E. Sanchez-Sinencio and D. Baez-Lopez, "On the SC filter by digital filter emulation," 25th Midwest symp. on circuits and systems, Houghton, pp. 440-3, August 1982. (E)

[169] S.M. Faruque, M. Vlach, J. Vlach, K. Singhal and T.R. Viswanathan," FDNR switched capacitor filter insensitive to parasitic capacitance," IEEE Trans. Circuits \& Syst., vol. 29, no. 9, pp. 569-95, Sept. 1982. (D)

[170] "Applikator switched capacitor filter," Electron. Lett., vol. 8, no. 9, pp. 42-5, Sept. 1982. (D)

[171] T. Kunieda and K. Kato, "Effect of the switched capacitor finite onresistance on the performance of switched capacitor integrator," Trans. Inst. Electron. \& Communi. Engg, Sect. E, vol. 65, no. 9, pp. 254, Sept. 1982. (B)

[172] P.V. Anand Mohan, V. Ramchandran and M.N.S. Swamy, "Terminations for component simulation type SC ladder filters," Electron. Lett., vol. 19, no. 1, pp. 92-5, Sept. 1982. (D) 
[173] M. Graham, "Switched capacitor filters," Radio \& Electron. World, vol. 10, no. 12 , pp. 16-18, Sept. 1982. (D)

[174] F. Anaday, "Realization of Norton amplifier nth-order SC networks" Int. J. Electron., vol. 53, no. 3, pp. 289-92, Sept. 1982. (A)

[175] C. Lau and J.I. Sewell, "Compact matrix scheme for use in computer analysis of switched capacitor circuits," Electron. Lett., vol. 18, no. 19, pp. 84015, Sept. 1982. (A)

[176] J.T. Taylor, "Exact design of elliptic switched capacitor filter by synthesis." Electron. Lett., vol. 18, no. 19, pp. 80-79, Sept. 1982. (D)

[177] C. Karagoz and C. Acar, "Active switched capacitor realization for Nth order voltage transfer function, a signal flow graph approach," Int. J. Circuit Theory \& Appl., vol. 10, no. 4, pp. 377-82, Oct. 1982. (D)

[178] H. Jamal and F.E. Holmes, "Novel switched capacitor integrator circuits," Int. J. Circuit Theory \& Appl., vol. 10, no. 4, pp. 383-06, Oct. 1982. (B)

[179] R. Lucker, "Frequency domain analysis of switched capacitor circuits using Z-domain transfer function evaluation," AEU, vol. 36, no. 18, pp. 383-92, Oct. 1982. (A)

[180] C. Karagoz and C. Acar, "Stray insensitive switched capacitor network realization for Nth order voltage transfer functions," Electron. Lett. vol. 18, no. 22, pp. 966-7, Oct. 1982. (D)

[181] S.D. Bedrosia and S.I. Refai, "Switched capacitor network, analysis and fault diagnosis," Sixteenth Asilomar conf. circuits, systems, and computers, Pacific Grove, pp. 316-20, Nov. 1982. (A)

[182] R. Gregorian, "Op amp DC offset elimination methods in switched capacitor biquad," Sixteenth Asilomar Conf. on circuits, systems and computers, Pacific Grove, pp. 120-2, Nov. 1982. (D)

[183] G.A. Nenvo, "Synthesis of SC-filters by means of oriented graphs," Electro. Prom-st \& priborostr., vol. 17, no. 10, pp. 443, Nov. 1982. (D)

[184] T. Orr, "Designer's notebook (switched-capacitor filters)," Electron. Today, Ind., vol. 11, no. 11, pp. 45-8, Nov. 1982. (H)

[185] D.F. Lewis, "Switched capacitor filter for phase locked loop," Electron. Lett, vol. 15, no. 22, pp. 18, Nov. 1982. (D)

[186] F. Maloberti and F. Montecchi, "Parasitic insensitive toggle switched capacitor and its application to switched-capacitor networks," Electron. Lett., vol. 18, no. 24, pp. 1061, Nov. 1982. (A)

[187] S. Manetti, "New technique for the realization of passive switched capacitor low pass filters," Altra. Frequency, vol. 51, no. 6, pp. 319, Nov. 1982. (D)

[188] W.K. Jennins and N.D. Naguyn, "Computer modelling of clock feed through distortion in switched capacitor circuits," Sixteenth Asilomar Conf. on circuits, systems and computers, Pacific Grove, pp. 197-30, Nov. 1982. (H)

[189] J.A. Guinea and D. Senderowiez, "A differential narrow-band switched capacitor filtering technique," IEEE J. Solid State Circuits, vol. 17, no. 6, pp. 1029-38, Dec. 1982. (D)

[190] Bang Won Lee and Song Bae Park. "Analysis of nonideal voltage inverter switch and its application to switched capacitor design," J. Korea Inst. Electron. Engg. vol. 19, no. 6, pp. 41-51, Dec. 1982. (A) 
[191] G. Fischer and G.S. Moschytz, "High-Q SC biquad with minimum capacitor spread," Electron. Lett., vol. 18, no. 25-26, pp. 1086-9, Dec. 1982. (D)

[192] M.S. Tawfik, C. Terrier, C. Caillon and J. Borel, "Exact design of switchedcapacitor band pass ladder filter," Electron. Lett., vol. 18, no. 25-26, pp. 110, Dec. 1982. (D)

[193] N. Fliege and W. Brandenbusen, "Multiple parameter tunable active integrator filters," IEEE Trans. Circuits \& Syst., vol. 29, no. 12, pp. 848-51, Dec. 1982. (D)

[194] R.D. Jolly and R.H. Mccharles, "A low-noise amplifier for switched capacitor filters" IEEE J. Solid State Circuits, Vol. 17, no. 17, pp. 1192-4, Dec. 1982. (D)

[195] D.C. Von Gruenigen, R. Sigg, M. Ludwig, U.W. Brugger, G.S. Moschytz and $H$. Melchior, "Integrated switched capacitor low pass with combine antialiasing decimation filter for low frequencies," IEEE J. Solid State Circuits, vol. 17, no. 6, pp. 1028-9, Dec. 1982. (D)

[196] E. Hayahara and Y. Asano, "SCF realization based on the simulation of node equation," Trans. Inst. Electron. Communi. Engg. Part-A, vol. 65A, no. 12, pp. 1233-8, Dec. 1982. (D)

[197] U. Lusenko, "Frequency-voltage converter with a switched capacitor," Rev. Esp. Electron., vol. 29, no. 337, pp. 42. Dec. 1982. (G)

1983

[198] L.T. Bruton, G. R. Bailey and G. Bhattacharjee, "Loop equation formulation for switched capacitor networks containing nullor," Int. J. Circuit Theory \& Appl., vol. 11, no. 1, pp. 57-72, Jan. 1983. (A)

[199] B. D. Nelin, "Analysis of switched-capacitor networks using general purpose circuit simulation program," IEEE Trans Circuits \& Syst., vol. 30, no. 1, pp. 43-8, Jan. 1983. (A)

[200] J. Pandel, "Scaling techniques for switched capacitor filters employing voltage inverter switches," Int. J. Circuit Theory \& Appl., vol. 11, no. 1, pp. 7376, Jan. 1983. (D)

[201] C.A. Gobet and A. Knob, "Noise analysis of switched capacitor networks," IEEE Trans Circuits \& Syst., vol. 30, no. 1, pp. 37-43, Jan. 1983. (A)

[202] G. Kabuli and F. Anday, "Stray insensitive switched capacitor network realization for voltage transfer functions," Electron. Lett., vol. 19, no. 2, pp. 60, Jan. 1983. (A)

[203] B. Mossner and K. Sauer, "Noise properties of SC part circuits", Nathrichten. Elektronik, vol. 33, no. 8, pp. 323-7, Jan. 1983. (A)

[204] J. Lippman and K. Saer, "User-oriented optimization of filter with switched capacitor," Nachrichten. Electronik, vol. 33, no. 8, pp. 327-32 Jan. 1983. (D)

[205] B. Donnelly, "Switched capacitor array semi-custom filters design," Electron. Lett., vol. 19, no. 7, pp. 11-13, Jan. 1983. (D)

[206] J. Pandel and H. Dawei, "New realization of inductances for switched capacitor filters using voltage inverter switches," Circuits Syst. \& Signal Processing, vol. 2 , no. 4, pp. 469-85, Jan. 1983. (F) 
[207] M. Arnoldt, "Switched-capacitor filter as narrow band receiver demodulator," Electronik, vol. 33, no. 1, pp. 65-7. Jan. 1983. (D)

[208] B. Furrer and W. Guggenbuhl, "Noise analysis of a switched capacitor biquad," AEU, vol. 37, no. 12, pp. 35-40, Feb. 1983. (D)

[209] C. Karagoz and C. Acar, "Active switched capacitor filter realization for a biquad-ratio voltage transfer function," Inst. J. Electron., vol. 54, no. 2, pp. 211-20, Feb. 1983. (D)

[210] J. Pandel, "Compensation of the effects of top plate capacitances in VISSC filters," AEU, vol. 37, no. 1-2, pp. 65, Feb. 1983. (D)

[211] P.V. Anand Mohan, V. Ramchandran and M.N.S. Swamy, "High pass and 2nd-order switched capacitor filters," IEE, Proc. G, vol. 130, no. 1, pp. 1-6, Feb. 1983. (D)

[212] R.D. Fellman and R.W. Broderson, "A switched capacitor adaptive lattice filter," IEEE, Trans. ASSP, vol. 31, no. 1, pp. 294-304, Feb. 1982. (D)

[213] J. Taylor, "Stability test for switched capacitor filters," Electron. Lett., vol. 19, no. 3, pp. 89-91, Feb. 1983.

[214] W. Twaddell, "Switched capacitor-array introductions herald semi-custom analog flexibility," EDN, vol. 28, no. 4, pp. 45-8, Feb. 1983 (H)

[215] T.C. Choi, R.T. Kaneshiro, R. Broderson and P.R. Gray, "High frequency CMOS switched-capacitor for communication application," IEEE Int. Conf. on Solid State Circuits, pp. 246-7, Feb. 1983. (H)

[216] W. B. Mikhael and S. Tu, "Continuous and switched capacitor multi phase oscillator," IEEE Trans Circuits \& Syst. vol. 31, no. 280-93, pp. 280-93, March 1983. (C)

[217] T. Nishi, "Synthesis of biphase switched capacitor circuits," Trans Inst. Electron. \& Communi. Engg. Jpn. Part. A vol. J66A, no. 3, pp. 171-8, March 1983 (A)

[218] G. Fischer and R. Plodeck, "SCANAL: a simulation program for switchedcapacitor networks," Bull. Assoc. Suise, Electr. vol. 741, no. 5, pp. 230-3, March 1983. (A)

[219] M. Ishikawa, "A synthesis of impedance simulation type SCF using voltage followers," Trans.. IECE, vol. J66A., no. 3, pp. 286-7, March 1983. (F)

[220] P.V. Anand Mohan, V. Ramachandran and M.N.S. Swami, "Formulae for dynamic range of second order discrete time filters," IEEE Trans Circuits. \& Syst. vol. 30, no. 5, pp. 321, March 1983. (D)

[221] G. Lainey, R. Saintlaurens and P. Senn, "Switched capacitor second order noise-shaping coder," Electron. Lett., vol. 19, no. 4, pp. 149-8 March 1983. (H)

[222] F. Maloberti, "Switched-capacitor building blocks for analogue signal processing," Electron. Lett., vol. 19, no. 7, pp. 263-5, March 1983. (A)

[223] M. Tanaka and A. Fujikawa, "Switched-capacitor filter analysis," Natt. Tech. Rep., vol. 9, no. 2, pp. 289-95, April 1983. (D)

[224] H. Pinier, F. Krummeracher and V. Valenac, "A micro power sixth order switched capacitor filter with leapfrog low pass filter," Mitt. Agen., no. 36, pp. 19-24, April 1983. (D)

[225] M. Tanaka and A. Fujikawa, "Switched capacitor filter LSI," Natt. Tech Rep., vol. 29, no. 2, pp. 289, April 1983. (D) 
[226] R. A. Penfold, "Switched-capacitor phaser," Pract. Electron., vol. 19, no. 4, pp. 40-3', April 1983. (H)

[227] W.L. McCall, S.M. Riad and F.W. Stephenson, "Switched capacitor filter design aids," IEEE South Eastcon 83 Conf. Proc. Orland, pp. 11-14, April 1983. (D)

[228] L. Claesen, H. de. Man, J. Vandewalle and J. Rabaey," DIANASC, a versatile top down analysis tools for switched capacitor circuits," Microelectron. J., vol. 14, no. 2, pp. 37-53, April 1983. (A)

[229] K. Nakayama, Y. Ishikawa and Y." Kuaishi, "Design of LSI spectrum analyzer using switched capacitor technique," Proc. of Int. Conf. on ASSP pp. 523-6, April 1983. (A)

[230] P. Lutz and H. Weinrichter, "Direct and image frequency transformation of time variant switched capacitor networks," Electron. Lett., vol. 19, no. 9, pp. 354-5, April 1983. (A)

[231] R. Sigg, "Integrated switched capacitor low pass filter with combined antialiasing decimation filter for low pass frequency," Mitt. Agen., no. 36, pp. 336, May 1983. (D)

[232] H. Pinier, F. Krummeracher and V. Valenac, "A micro power sixth order switched capacitor filter with leapfrog low pass filter," Mitt. Agen., no. 36, pp. 19-24, May 1983. (D)

[233] P.V. Anand Mohan, V. Ramchandran and M.N.S. Swami, "Stray sensitivity higher order switched-capacitor filters," 83 IEEE Int. symp. on circuits and systems, Newport Beach, USA, pp. 303, vol. 2, May 1983. (D)

[234] J. Vlach, K. Singhal, M. Vlach, R. Chanda and J. Barby," Computer methods in the analysis and design of networks", 83 IEEE Int. symp. on circuits and systems, Newport Beach, USA, pp. 427-30, vol. 1, May 1983. (A)

[235] M.J. Nigam and M.M. Krishna, "Synthesis of switched capacitor filters using FDNR type second-order time dependence capacitor in P-domain," Int. J. Electron., vol. 54, no. 5, pp. 701-4, May 1983. (F)

[236] R.T. Kaneshiro,' T.C. Choi, R.W. Broderson and P.R. Gray, "High frequency switched capacitor filtering techniques," 83 IEEE Int. symp. on circuits and systems, New Port Beach USA, pp. 797-802, vol. 2, May 1983. (D)

[237] M.S. Tawfik, C. Terrier, C. Caillon and J. Borel, "Exact design of switched capacitor band pass ladder filters," 83 IEEE Int. Symp. on circuits and systems, Newport Beach, USA, vol. 2, pp.793-6, May 1983. (D)

[238] Hsu Teng Hsien and G.C. Temes, "Low sensitivity digital filter design from a switched-capacitor filter prototype," 83 IEEE Int. symp. on circuits and systems, Newport Beach, USA, pp. 282-5, vol. 1, May 1983. (D)

[239] G.A. Nenov, "A signal flow graph approach of SC filters with unity gain buffer," 83 IEEE Int. symp. on circuits and systems, Newport Beach, USA, pp. 803, vol. 2, May 1983. (D)

[240] U.W. Brugger, G.S. Moschytz and E. Hokenek, "Signal flow graph analysis of SC networks comparing integrators," IEEE Int. symp. on circuits and syst., New Port Beach, pp. 67, May 1983. (A)

[241] B.B. Bhattacharyya and R. Raut, "On the analysis of active switchedcapacitor networks considering the finite value of the DC gain and gain bandwidth 
product of the op amp", 83 IEEE Int. symp. on circuits and systems, New Port Beach, USA, pp. 65-7, vol. 2-4, May 1983. (A)

[242] R.D. Davis, "The use of bilinear transformations in switched-capacitor ladder filters", 83 IEEE Int. symp. on circuits and systems, New Port Beach, USA, pp. 758-8, vol. 2, May 1983. (D)

[243] E.I. EI-Masry and A.A. Sakla, "A realization of switched capacitor filters using biquads," 83 IEEE Int. symp. on circuits and systems, Newport Beach, USA, pp. 785-8, May 1983. (D)

[244] C. Sato and H. Fujiaka, "Stability of switched capacitor filter possessing varying parameter," 83 IEEE Int. symp. on circuits and systems, New Port Beach, USA, pp. 52-9, vol. 1, May 1983. (D)

[245] J.G. Ye and O. Wing, "Sensitivity analysis of SCN's with arbitrary inputs," 83 IEEE Int. symp. on circuits and systems, New Port Beach, USA, pp 56-9, vol. 1, May 1983. (A)

[246] S.C. Fan, Y.P. Tsividis and O. Wing, "Efficient algorithms for analyzing many phases switched capacitor networks," 83 IEEE Int. symp. on circuits and systems, New Port Beach, USA, pp. 60-3, vol. 1, May 1983. (A)

[247] D.J.L. Lewis, "Switched capacitor filters for Phase Locked Loop," Electron. Engg., vol. 55, no. 677, pp. 27-8, May 1983. (D)

[248] J.J. Mulawka and A. Pakulok, "A switched capacitor phase locked loop employing current controlled oscillator," Proceeding of Melcon Greece, vol. 1, pp. 108, May 1983. (C)

[249] T.D. Mok, P.A. Ateshiana and C.W. Solomon, "A mask programmable SCF and logic array for semi-custom analog system integrator," 83 IEEE Int. symp. on circuits and systems, New Port Beach, USA, pp. 272-6, May 1983. (D)

[250] S. Eriksson and H. Akhlaghi, "Noninverting parasitic compensated bilinear SC integrator with only one op amp," Electron. Lett., vol. 19, no. 12, pp. 450-2, June 1983. (B)

[251] J. Mikula, "The $\mathrm{Z}$ parametric transformation and its application to the design of switched-capacitor filters," Slaboproudy Obz., vol. 144, no. 6, pp. 26973, June 1983. (D)

[252] G. Fischer and G.S. Moschytz, "SC integrator for high frequency applications," Electron. Lett., vol. 19, no. 13, pp. 495-6. June 1983. (B)

[253] P.M. Van Peteghem and W. Sansen, "T-cell SC integrator synthesis very large capacitance ratios," Electron. Lett., vol. 19, no. 14, pp. 541-3, July 1983. (B)

[254] M. Cooperman, "Integrated switched-capacitor FDNR filter," IEEE, J. Solid State Circuits, vol. 18, no. 4, pp. 378-83, August 1983. (D)

[255] M. Ishikawa, "Bilinear transformed switched-capacitor immittance converter," Trans. Inst. Electron. \& Communi. Jpn. Sect. E, vol. 66, no. 8, pp. 4989, August 1983. (F)

[256] D.G. Cox, "Digitally programmable switched-capacitor universal active/ oscillator," IEEE, J. Solid State Circuits, vol. 18, no. 4, pp. 374-83, August 1983. (C)

[257] P.P. Vaidyanathan and S.K. Mitra, "Design and analysis of switched capacitor filters using single operational amplifier," Proc. of the 26 Midwest Symp. on Circuits \& Syst. Mexico, pp. 434-9, August 1983. (D) 
[258] F. Montecchi and F. Maloberti, "Switched-capacitor ladder filters for high frequency application via bilinear resistance modelling," Proc. of 26 Midwest Symp. on Circuits \& Syst. Maxico, pp. 445-8, August 1983. (D)

[259] E.R. Klinkovsky and W.A. Serverin, "A practical approach to the design, analysis and sensitivity of switched-capacitor biquads," Proc. of 26 Midwest Symp. Circuits \& Syst. Puilba Maxico, pp. 440-4, August 1983. (D)

[260] S.C. Fang, Y.P. Tsividis and O. Wing, "SWITCAP, a switched capacitor network analysis program I. basic feature," IEEE Circuits \& Syst. Mag. vol. 5, no. 3, pp. 4-10, Sept. 1983. (A)

[261] K. Koch, "Network harmonic oscillation analyzer with switched capacitor filters," Elektronik, vol. 32, no. 18, pp. 99, Sept. 1983. (D)

[262] A. Jenning, "Switched-capacitor equalizer structure," Sydeny Australia Radio \& Electron. Engg. Sept. 1983. (H)

[263] B. Mosser and K. Saner, "Noise properties of SC port circuits," Nachrichten" Electronik, vol. 33, no. 8, pp. 323-7. Sept. 1983. (A)

[264] B.J. Hosticka, W. Brockerde, U. Kleine and G. Zimmer, "Switched capacitor fsk modulation and demodulation technology," 9th European Solid State Circuits Conf. Lausanne, Switzerland. vol. 1, pp. 213-16, Sept. 1983. (H)

[265] M.G. Degrauwe, F. Salchli, "A multi-purpose micro power switched capacitor filter," Ninth European Solid State Circuits Conference, Lausanne, Switzerland. pp. 127-30, Sept. 1983. (D)

[266] G.J. Smolka, "Switched capacitor band pass filter based on simulation of canonical reactance sections," Ninth European Solid State Circuits Conf. Lausanne, Switzerland, pp. 187-90, Sept. 1983. (D)

[267] J. Pandel and H. Dawei, "Analysis of switched capacitor filters," Int. J. Circuits Theory \& appl. vol. 11, no. 4, pp. 377-95, Oct., 1983. (D)

[268] U. Kumar. "Novel SC realization of floating FDNC," Microelectron. J., vol. 14, no. 5, pp. 31-4, Oct. 1983. (F)

[269] T.H. Hsu, and G. C. Temes, "Improved input stage for bilinear switched capacitor ladder filters," IEEE Trans Circuits and Systems, vol. 30, no. 10, pp. 758-10, Oct. 1983. (D)

[270] C. Sato and H. Fujisaka, "Stability of switched capacitor filter possessing periodic parameters," Trans Inst. Electron \& Communi. Engg., vol. 66, no. 11, pp. 940-6, Oct. 1983. (D)

[271] A. Kumar and S.K. Saha, "MOS switched capacitor sample data filters," Int. J. Electron., vol. 55, no. 4, pp. 631-7, Oct. 1983. (D)

[272] A. Liberator and S. Maoetti, "Filters with switched capacitor," Electron. Oggi., no. 10, pp. 163, Oct. 1983. (D)

[273] J. Pandel and H. Dawei, "Analysis of wave switched capacitor filters," Int. J. Circuit Theory \& Appl., vol. 11, no. 4, pp. 377-95. Oct. 1983. (D)

[274] J.J. Mulawka and A. Pakulak, "Application of switched capacitor techniques to realization of phase locked loop," Elektronika, vol. 24, no. 6, pp. 2931, Nov. 1983. (A)

[275] P.V. Anand Mohan, V. Ramchandran and M.N.S. Swami, "Capacitor spread evaluation of stray insensitivity SC biquads," IEEE Trans Circuits \& Syst. vol. 30 , no. 11, pp. 847 , Nov. 1983. (D) 
[276] N. Attaie, "Inverse follow the ladder feedback switched capacitor structure," Seventeenth Asilomar symp. on circuits, systems and computers, Pacific Grove, pp. 504-5, Nov. 1983. (H)

[277] A. Hedayati, "Designing of completely parasitic-insensitivity, wide band bilinear switched capacitor high pass ladder filter," Seventeenth Asilomar conf. on circuits, systems and computers, Pacific Grove, pp. 495-9, Nov. 1983. (D)

[278] P.P. Vaidynathan and S.K. Mitra, "Spectral transmission in switched capacitor filters," Seventeenth Asilomar conf. on circuits, systems and computers, Pacific Grove, pp. 505-9, Nov. 1983. (D)

[279] T. Enomdo, T. Ishikara and M. Yasumodo, "Integratable MOS offset error canceller for analogue adaptive transversal filter," Electron. Lett. vol. 19, no. 23, pp. 965-70, Nov. 1983. (D)

[280] T. Inoue and F. Ueno, "Parasitic compensated building blocks for switched capacitore filters," Electron. Lett., vol. 19, no. 23, pp. 970, Nov. 1983. (D)

[281] M. Kaneko, H. Kunieda and M. Onoda, "Topological formulas for switched capacitor networks," Trans. Inst. Electron. Engg. Jpn. Part. A, vol. J66A, no. 11 , pp. 1080 , Nov. 1983. (A)

[282] P.V. Anand Mohan, V. Ramachandran and M.N.S. Swami, "Capacitor spread evaluation of stray insensitive SC circuits biquad," IEEE Trans. Circuits \& Syst., vol. 30, no. 11, pp. 847, Nov. 1983. (D)

[283] V. Alessandroni, "The national presents their new universal switched capacitor monolithic filters," Electron. Oggi., no. 11, pp. 144-50, Nov. 1983. (D)

[284] R. B. Datar and A.S. Sedra, "Exact design of stray insensitive switched capacitor high pass ladder filters," Electron. Lett., vol. 19, no. 24, pp. 1010-12, Nov. 1983. (D)

[285] S. Neyton and V. Wilkinson, "Source based switched capacitor hybrid saw oscillators," IEE Proc. G., vol. 130, no. 7, pp. 473-6 Dec. 1983. (C)

[286] T. Suzuki, H. Takatori, H. Shirasu, M. Ogawa and N. Kunumi, “A CMOS switched capacitor variable equalizer," IEEE J. Solid State Circuits, vol. 18, no. 9-10, pp. 700-76, Dec. 1983. (H)

[287] S. Giochina, "Nodal equation of switched-capacitor filters," Rev. Roum. Sci. Tech. Ser. Electroteech. \& Engg., vol. 28, no. 4, pp. 373-82, Dec. 1983. (D) [288] S.I. Miroschnichenoko, "Space-time SC circuits," Radio Electron. \& Communi. Syst., vol. 25 , no. 11 , pp. $75-7$, Dec. 1983. (H)

[289] H. Jamal and H. Zafrullch, "Simple switched capacitor voltage controlled oscillator," IEE Proc. G., vol. 130, no. 6, pp. 263-6, Dec. 1983. (C)

[290] P.V. Anand Mohan, V. Ramachandran and M.N.S. Swami, "Analysis of SC networks using continuous-time four port equivalents," Electron. Lett., vol. 19, no. 25-26, pp. 1094, Dec. 1983. (A)

\section{4}

[291] G.J. Smolka, "Synthesis of switched capacitor filters simulation canonical reactance section for high power application," Frequenz, vol. 38, no. 2, pp. 3743, Jan. 1984. (D) 
[292] A.H.M. Roermund Van and P.M.C. Coppelmaıns, "An integrated switched capacitor filter for view date," Philips Tech Rev., vol. 41, no. 4, pp. 105, Jan. 1984. (D)

[293] B.B. Bhattacharya and R. Raut, "Design of parasitic tolerant switched capacitor filters using unity gain buffer," IEE Proc. G., vol. 131, no. 3, pp. 103, Jan. 1984. (D)

[294] D.M. Divan, "Non dissipative switched networks for high power application," Electron. Lett. vol. 20, no. 7, pp. 277-9, Jan. 1984. (H)

[295] V. Seidel, "Realization of high pass filters its active RC and SC integrator," Natchrichten. Elektronik, vol. 34, no. 8, pp. 310-12. 1984. (D)

[296] S. Manetti. "Passive switched-capacitor filters general biquad topology," Electron. Lett., vol. 20, no. 2, pp. 101-2, Jan. 1984. (D)

[297] A. Cichocki and R. Unbehauen, "Novel switched capacitor generalised integrator," Electron. Lett., vol. 21, no. 4, pp. 154-9 Feb. 1984. (B)

[298] B.B. Bhattacharaya and R. Raut, "Parasitic tolerant design of sampleddata filters using switched capacitor and unity gain amplifiers," J. Franklin Inst., vol. 317, no. 1, pp. 35-54 1984. (D)

[299] J.J. Mulawka and G.S. Moschytz, "Method of simplified analysis of switched capacitor networks," Electron. Lett., vol 21, no. 4, pp. 138-9, Feb. 1984. (A)

[300] C.F. Lee, R.D. Davis, W.K. Jenkins and T.N. Trick, "Sensitivity and nonlinear distorsion analysis for switched capacitor using SCAPN," IEEE Trans., Circuits \& Syst., vol. 31, no. 21, pp. 218-21, Feb. 1984. (A)

[301] M. Yasumomto, T. Enomoto, K. Watarnable and T. Ishihara, "Single chip adaptive transversal IC employing switched capacitor technology," IEEE. J. Sel. Area. Communi., vol. 2, no. 2, pp. 324-33, March 1984. (H)

[302] J. Vlach and E. Christen, "Poles zeros and their sensitivity in switched capacitor networks," IEEE Trans Circuits \& Syst., vol. 32, no. 3, pp. 279-84, March 1984. (A)

[303] J. Pandal and A. Fettweis, "Analysis of VIS-SC filters," Acta. Electon., Sin., vol. 12, no. 2, pp. 9-14, March 1984. (D)

[304] S. Signell, "On selectivity properties of discrete-time linear networks," IEEE Trans Circuits \& Syst. vol. 31, no. 3, pp. 275-80, March 1984. (A)

[305] G.A. Nanov, "Modified signal flow graph approach to synthesis of SC filter with unity gain," Int. J. Electron., vol. 56, no. 3, pp. 413-18, March 1984. (D)

[306] Umesh Kumar, "Analysis of switched capacitor networks," IEEE Circuits and System Magzine \& Syst., vol. 16, no. 1, pp. 1-15, March 1984. (A)

[307] A. E. Eremenko, "Highly selective switched capacitor filters using integrated circuits," Instrument \& Exp. Tech., vol. 27, no. 2, pp. 381, March 1984. (D)

[308] P. Gillingham, "Stray free switched-capacitor unit delay circuit," Electron. Lett., vol. 20, no. 7, pp. 308-10, March 1984. (H)

[309] U. Kleine, "Design of wave-SC filter using building block," Int. J. Circuit Theory \& Appl., vol. 12, no. 2, pp. 69-87 April 1984. (D)

[310] F. Montecchi, "Time shared switched capacitor ladders insensitive to par- 
asitic effects," IEEE Trans Circuit \& Syst., vol. 31, no. 4, pp. 349-53, April 1984. (D)

[311] N. Takahashi, T. Takebe and K. Inomata, "A new recursive structure for very high Q digital and SC-CTD filters". Trans Inst. Electron. \& Communi. Engg. vol. 67 , no. 4, pp. 293-300, April 1984. (E)

[312] B.J. Hosticka, W. Brockerde, U. Kleine and R. Schweer, "Design of nonlinear analog switched capacitor circuits using building blocks," IEEE Trans Circuits \& Syst., vol. 31, no. 4, pp. 354-68, April 1984. (A)

[313] N.S. Reddu and M.N.S. Swami, "Switched capacitor realization of FIR filters," IEEE Trans. Circuits \& Syst. vol. 31, no. 4, pp. 417-19, April 1984. (E)

[314] H. Baher and S.O. Scanlan, "Exact synthesis of band pass switched capacitor LDI ladder filters," IEEE Trans Circuits \& Syst., vol. 31, no. 4, pp. 342 9, April 1984. (D)

[315] Xiong Tongzhou, Shi Huichang and Lu Mingda, "A methode of evading floating voltage inverter switches in SCF," J. China Inst. Communi., vol. 5, no. 2, pp. 1-6, April 1984. (D)

[316] J.A.C. Bingham, "Application of a direct transfer SC integrator," IEEE Trans Circuits \& Syst., vol. 31, no. 4, pp. 419-20, April 1984. (D)

[317] J.H. Nevin and K.K. Chi, "A MOS transresistance amplifier with switched capacitor feedback," Proc. of IEEE Conf. Southeastech, pp. 4-7, April 1984. (B)

[318] A. Jenning and K.K. Pang, "Switched capacitor equalizers for time compression multiplex digital transmission," Int. Conf. on Consumer \& Industrial Electronics, (New York USA IEEE) pp.110-12, April 1984. (H)

[319] M. Sasikumar, K. Radhakrishan. Rao and M.A. Raddy, "Programmable switched-capacitor filter with no additonal silicon area," Proceeding IEEE vol. 72, no. 5, pp. 648-50, May 1984. (D)

[320] M. Sasikumar, K. Radhakrishan Rao and M.A. Reddy, "A general compensation for switched capacitor double integrator biquard," IEEE Trans. Circuits \& Syst. vol. 36, no. 1, pp. 4-6, May 1984. (D)

[321] M. Sasikumar, K. Radhakrishan Rao and M.A. Reddy, "Large signal instability in the switched capacitor double integrator biquad," 1984 IEEE Int. symp. on circuits and systems, Proceeding Montreal, Canada, pp, 1065-8, May 1984 (D)

[322] R. Chadha, K. Singhal and J. Vlach, "Sequential orthogonal transformation for frequency domain analysis of switched-capacitor networks," 1984 IEEE Int. symp. on circuits and systems, proceeding Montreal, Canada, vol. 3, pp. 131619, May 1984. (A)

[323] G.A. Lampropoulos and L.E. Peppard, "New technique to analyze active switched capacitor networks," 1984 IEEE Int. symp. on circuits and systems, proceeding Montreal, Canada, pp. 1320-3 vol. 3, May 1984. (D)

[324] J.A. Papadokis, "Linear transformations for switched capacitor filter design," 1984 IEEE Int. symp. oncircuits and systems, proceeding Montreal, Canada, vol. 1, pp. 308-11, May 1984. (D)

[325] J.C.M. Bezmudez and B.B. Bhattacharyya, "On the generation, design and optimization of switched capacitor biquad," 1984 IEEE Int. symp. on circuits and systems, proceeding Montreal, Canada, vol. 1, pp. 296-9, May 1984. (D) 
[326] M. Kaneko and M. Onoda, "Z-domain exact design for LDI leapfrog switched capacitor filter," 1984 IEEE Int. symp. on circuits and systems, proceeding Montreal, Canada, vol. 1, May 1984. (D)

[327] S.L. Farchy, E.D. Gadzheva and T. G. Kouyoumdjiev, "Computer aided analysis of SC circuits," 1984 IEEE Int. symp. on circuits and systems proceeding Montreal, Canada, vol. 3, pp. 1332-5 May 1984. (A)

[328] L. Toth and E. Simonyi, "Analysis of multiphase SC filter," 1984 IEEE Int. symp. on circuits and systems, proceeding Montreal, Canada, vol. 3, pp. 132831, May 1984. (D)

[329] M. Haser and M. Saghafi, "Switched capacitor biquads for leapfrog filters," 1984 IEEE Int. symp. on circuits and systems, Montreal, vol. 1, pp. 300-1, May 1984 (D)

[330] D.G. Johnson and J.I. Sewell, "Some improvement schemes for the interpolative symbolic analysis of switched capacitor networks," 1984 IEEE Int. symp. on circuits and systems, proceeding Montreal, Canada, vol. 3, pp. 1325-7, May 1984. (D)

[331] B.M. Guffin and B. Liu, "Low sensitivity switched capacitor filters using all pass building blocks," 1984 IEEE Int. symp. on circuits and systems, proceeding Montreal, Canada, pp. 288, vol. 1. May 1984 (D)

[332] N.H. Zhou, "Single pole operational amplifier effects on the performance of switched-capacitor," 1984 IEEE Int. symp. on circuits and systems, proceeding Montreal, Canada, pp. 1046-9, vol. 3, May 1984. (B)

[333] K. Kato, "Variable switched capacitor bandpass, bandelimination filters and all pass networks," 1984 IEEE Int. symp. on circuits and systems, proceeding Montreal, Canada, pp. 809-12, vol. 2, May 1984. (D)

[334] K. Nishikawa, T. Takebe and M. Hayashihara, "Two dimensional switched capacitor filters," 1984 IEEE Int. symp. on circuits and systems, proceeding Montreal, Canada, vol. 2, pp. 76, May 1984. (D)

[335] S. Signell, "A bilinear switched capacitor band pass filter with independent selectivity and frequency adjustments," IEEE Int. Symp. on Circuits \& System Proc., Montreal, Canada, pp. 802-4, vol. 2, May 1984. (D)

[336] H. Kunieda and A. Ohshimo, "State space approach to the design for low pass and bandpass sensitivity," 1984 IEEE Int. symp. oncircuits and systems, proceeding, Montreal, Canada, pp. 292, vol. 1, May 1984. (D)

[337] E. Hokenek and G.S. Moschytz, "Reduction of finite gain bandwidth effects on the performance of bilinear transformance admittance scaled SC ladder filters," 1984 IEEE Int. symp. oncircuits and systems, proceeding, Montreal, Canada, pp. 1050, vol. 3, May 1984. (D)

[338] L. Burson, S.H. Early, A. Ganesan, C.A. Goadwin and M.A. Novo, "Switched capacitor technique for high frequence filter," 1984 IEEE Int. symp. on circuits and systems, proceeding, Montreal, Canada, pp. 651-5, vol. 2, May 1984. (D)

[339] J.L. Huertas, R. Rodriguez-Vezquez and A. Rueda, "Low order polynomial curve fitting using switched capacitor circuits," 1984 IEEE Int. symp. oncircuits and systems, proceeding, Montreal, Canada, pp. 1123-6, May 1984 (H)

[340] R.B. Datar, A.S. Sedra and M.W. Chomik, "High frequency switchedcapacitor filter performance, limitation and design considerations," 1984 IEEE Int. 
symp. oncircuits and systems, proceeding, Montreal, Canada, pp. 696, vol. 2, May 1984. (D)

[341] E. Sanchez-Sinencio and R.L. Geiger, "Trade off between passive sensitivity output voltage sewing and total capacitances in SC filters," 1984 IEEE Int. symp. on circuits and systems, proceeding, Montreal, Canada, pp. 1062-4, vol. 3, May 1984. (D)

[342] A. Liberratore and S. Manetti, "On the realization of biquadratic section by using switched capacitor networks," 84 IEEE Int. Symp. on Circuits and systems, Proc., Montreal, pp. 85-8, vol. 1, May 1984. (D)

[343] J. Zurada and J.M. Smith, "Self tuning SC filters," 1984 IEEE Int. symp. on circuits and sysyems, proceeding, Montreal, Canada, vol. 2, pp. 805-8, May 1984. (D)

[344] K. Haug, G.C. Temes and K. Martin, "Improved offset compensation schemes for switched capacitor circuits," 1984 IEEE Int. symp. on cirrcuits and systems, Montreal, Canada, pp. 1054-3, vol. 3, May 1984. (A)

[345] F. Maloberti and F. Montecchi, "An offset compensated continuous feedback SC integrator for biquad section," 1984 IEEE Int. symp. on circuits and systems, Montreal, Canada, pp. 1058-61, vol. 3. May 1984. (D)

[346] E.A. Talkan, Y.Z. Bahnus and A.M. Hassan, "Nonidealness in switched capacitor circuits," 1984 IEEE Int. symp. on circuits and systems, proceeding, Montreal, Canada, pp. 1042-5, vol. 3, May 1984. (A)

[347] H.C. Patangia and B. Zenone, "A narrow band notch filter based on switched capacitor N-path filter principle," 1984 IEEE Int. symp. on circuits and systems, proceeding, Montreal, Canada, pp. 798-801, vol. 2, May 1984. (D)

[348] A.E.M. Prozbyliski and A.S. Sedra, "Speech recognition feature extraction using switched capacitor techniques in a VLSI circuits," 1984 IEEE Int. symp. on circuits and systems, proceeding, Montreal, Canada, pp. 166-70, vol. 1, May 1984 (H)

[349] N.S. Reddy and M.N.S. Swami "Switched capacitor realization of FIR filters," 1984 IEEE Int:' symp. on circuits and systems, proceeding, Montreal, Canada, pp. 69-72, vol. 1, May 1984 (D)

[350] D. Feng and S.D. Bedrosian, "Multiple fault diagnosis of analog circuits and its application to SC networks," 1984 IEEE Int. symp. on circuits and systems, proceeding, Montreal, Canada, pp. 693, vol. 2, May 1984. (A)

[351] J.E. Da. Franca, "Decimator and interpolator for narrow band switched capacitor band pass filter system," 1984 IEEE Int. symp. on circuits and systems, proceeding, Montreal, Canada, pp. 789-93, vol. 2, May 1984 (D)

[352] P.E. Fleischer, A. Ganesan and K.R. Laker. "A switched capacitor oscillator with precision ampitude control and guaranteed start up," 1984 IEEE Int. symp. on circuits and systems, Montreal, Canada, pp. 172, vol. 1, May 1984. (C)

[353] K. Watanable and G.C. Temes, "A switched capacitor digital capacitance bridge," 1984 IEEE Int. symp. on circuits and systems, Montreal, Canada, pp. 173-6, May 1984. (H)

[354] K.R. Laker, A. Ganesan and P.E. Fleischer, "Design and implementation of cascade switched capacitor delay equalizer," 1984 IEEE Int. symp. on circuits and systems, Montreal, Canada, pp. 171, vol. 1, May 1984. (H)

[355] R. Palomera-garcia, “Complementary property and fliege's transformation 
in switched capacitor networks," IEEE Int. symp. on circuits and systems, proc., Montreal, pp. 81-4, vol. 1, May 1984. (A)

[356] A.M. Davis, "Flow graph synthesis of darlington-cauer switched capactior filter," 1984 IEEE Int. symp. on circuits and systems, Montreal, Canada, pp. 1, vol. 77-80. May 1984. (D)

[357] Z.X. Zhou, "Narrow band switched capacitor filter with reduced total capacitors," 1984 IEEE Int. symp. on circuits and systems, Montreal, Canada, pp. 794-7, vol. 2, May 1984. (D)

[358] A. Lish, "A Z-plane lerner switched capacitor filter," 1984 IEEE Int. symp. on circuits and systems, Montreal, Canada, pp. 404-7, May 1984. (D)

[359] K. Nagraj and Ram kumar, "Switched-capacitor oscillator avoiding the use of large capacitor ratio," AEU, vol. 38, no. 3, pp. 216-18, June 1984. (C)

[360] D.T. Nguyen and B.D. Miller, "Equivalent RC circuit representation of switched capacitor networks," IEE Proc. G, vol. 131, no. 3, pp. 114-18, June 1984. (A)

[361] F. Ueno, T. Inoue and H. Ida, "Finite element analysis of the on-resistance effect of switch on the transit performance low power SC power supply," Trans. IECE, vol. J67C, no. 6, pp. 545-6, June 1984. (H)

[362] B.J. Hosticka, W. Brockherde, U. Kleine and G. Zimmer, "Switched capacitor fsk modulator and demodulator in CMOS technology," IEEE, J. Solid State Circuits, vol. 19, no. 3, pp. 389-96, June 1984. (H)

[363] Z.X. Zhou, "Simplified design oriented analysis of switched capacitor active filters," Int. J. Circuit theory and appl., vol. 12, pp. 179-189, June 1984 (A)

[364] J.L.A. Garcia-Vasquez and E. Sanchez-Sinencio, "Finite gain-bandwidth effect on a pair pseudo N-path SC filters," IEEE Trans circuits and systems, vol. 31, no. 6, pp. 583-4, June 1984. (H)

[365] M. Yamamoto and S. Mori, "A variable characteristic of switched capacitor circuit controlled by three phase clock," Trans Inst. Electron. \& Communi. Engg. vol. J67A, no. 6, pp. 614-5, June 1984. (H)

[366] S. Fushimi and K.'Nakayama, "A discreat optimization method of switched capacitor filter," Trans Electron. \& Communi. Engg., vol. J67A, no. 6, pp. 5807, June 1984. (D)

[367] E. Hayahara, "Equivalent RC circuit representation of switched capacitor networks and its applications," Trans Inst. Electron. \& Communi. Engg. vol. J67A, no. 6 , pp. 27 , June 1984 . (A)

[368] G.C. Temes, "Improve offset compensation schemes for switched capacitor circuits," Electron. Lett. vol. 120, no. 12, pp. 508, June 1984. (A)

[369] Umesh Kumar, "Generalized computer-aided exact nodal analysis of switched capacitor networks," Proc. of the 27th Midwest Symp. on circuits and systems, Margantown, vol. 1, pp. 288-91, June 1984. (A)

[370] C.S. Garngour, V. Ramchandran and B. Nowrouzian, "Design of biquadratic stray insensitive switched capacitor filters using unit delays and finite gain amplifiers as basic building blocks," Proc. of the 27th Midwest Symp. circuits and systems, Morgantown, pp. 2084-7, vol. 1, June 1984. (D)

[371] J. Zurada, "Programmable self turning filters: RC and SC," Proceeding of the twenty seventh Midwest Symp. on circuits and systems, Morgantown, pp. 763-6, vol. 2, June 1984 (D) 
[372] M.A. Styblinski, P.E. Allen, and B. Styblinski, "Optimal automated design of switched capacitor filters realized in VLSI Technology," Proc. of the 27th Midwest Symp. on circuits and systems, Morgantown, pp. 276-9, vol. 1, June 1984. (D)

[373] M.P. Faruque and A.A. Beex," Approaches to output noise spectral analysis for switched capacitor filters," Proc. of the 27th Midwest Symp. on circuits and systems, Morgantown, pp. 280-3, vol. 1, June 1984. (D)

[374] F. Montoecchi, "Switched capacitor pseudo N-path filters with improved noise characterized in pass band," Proceeding of the Twenty seventh Midwest Symp. on circuits and systems, Morgantown, USA, pp. 296-9, vol. 1, June 1984. (D)

[375] A.M. Davis and W.T. Small, "Switched capacitor ICs simplify filter design," EDN, vol. 29, no. 12, pp. 197-210, June 1984. (D)

[376] B. Furrer, J. Gotte, M.A. Copeland and K.K.K. Lam, "Comment on noise canelling switched capacitor filters," Electron. Lett., vol. 20, no. 13, pp. 5456, June 1984. (D)

[377] K. Chen and S. Eriksson, "Novel parasitic insensitive wave SC filters," Electron. Lett., vol. 20, no. 133, pp. 565-7, June 1984. (D)

[378] P. Christiansen, "Integrated filter circuits with switched capacitor," Funkschan, no. 13, pp. 61, June 1984. (D)

[379] H. Suzuli, "Proposal of two inputs terminals SC amplifier and its experimental results," Trans Inst. Electron. \& Communi. Engg. vol. 67C, no. 7, pp. 602, July 1984. (B)

[380] T. Kaneko, H. Kikuchi and A. Jwata, "Design technique for multiplexed switched capacitor filters," Trans Inst. Electron. \& Communi. Engg., vol. J71C, no. 7, pp. 585-95, July 1984. (D)

[381] D.G. Johnson and J.I. Sewell, "Improved Z-plane polynomial interpolative analysis of switched capacitor networks," IEEE Trans Circuits \& Syst., vol. 31, no. 7, pp. 666-8, July 1984. (A)

[382] H. Seki, M. Yamamoto and S. Mori, "Switched capacitor amplifier and application," Trans Inst. Electron. \& Communi. Engg., vol. J67A, no. 7, P. 67480, July 1984. (B)

[383] D. Bruchamnn and U. Kleine, "Integrated VIS-SC filter with lattice reference structures," Electron. Lett., vol. 20, no. 15, pp.627-8, July 1984 . (D)

[384] G. Fischer and G.S. Moschytz, "On the frequency limitation of SC filters," IEEE J Solid State Circuits, vol. 19, no. 4, pp. 510-18, August 1984. (D)

[385] B.J. Sheu, "Switched induced error voltage on a switched capacitor," IEEE

J. Solid State Circuits, vol. 19, no. 4, pp. 519-25, August 1984. (H)

[386] K. Chen, "Offset compensated switched capacitor leapfrog filters," Electron. Lett., vol. 20, no. 18, pp. 731-3, August 1984. (D)

[387] K. Nagraj, "Switched capacitor delay circuit that is insensitive to capacitor mismatch and stray capacitance," Electron. Lett., vol. 20, no. 16, pp. 663-4, August 1984. (H)

[388] U. Kleine, B.J. Hosticka and T. Wieja, "Novel programmable wave-SC filter structure for pole-zero modelling of vocal track," Electron. Lett., vol. 20, no. 16, pp. 670-2, August 1984. (D)

[389] I. Ooto, T. Inone and F. Ueno, "A realization of low pass using SC 
transformer and its analysis," Electron. \& Communi. Jpn, vol. 66, no. 2, pp. 914, August 1984. (D)

[390] D.G. Johnson, J.I. Sewell and A.D. Meankin. "Interpolation analysis of switched capacitor networks," IEE Colloquium on Design Software, London, England, August 1984. (A)

[391] J. Pandel, D. Bruckmann, A. Fettweis, B.J. Hosticka, V. Kleine, R. Schweer, and G. Zimmer, "An integrated 18th order VIS-SC pseudo-N-path filter," 10th European solid state conf., Edinburg, pp. 83-6, Sept. 1984. (D)

[392] K. Nakayama, S. Uriya, T. Matsura, and M. Mittama, "A personal transreceiver base band LSI using switched capacitor circuits technology," 10th European solid state conf., Edinburg, pp. 248-51, Sept. 1984 (H)

[393] K. Watanable and G.C. Temes, "A switched capacitor multiplier/divider with digital and analog output," IEEE Trans. Circuits \& syst, vol. 31 no. 9, pp. 796-800, Sept. 1984. (H)

[394] K. Watanable and K. Fujiuara, "Offset compensated switched capacitor circuits," Electron. Lett., vol. 20, no. 19, pp. 780-1, Sept. 1984. (H)

[395] C.R.W. Compbell and K.M. Reineck, "A pole/zero prewarping procedure in SC filter design," IEEE Trans. Circuits \& Syst., vol. 31, no. 9, pp. 821-5, Sept. 1984. (D)

[396] J. Slife, "Calculation program design filters built around MF to switched capacitor IC," Electron., Des. vol. 32, no. 9, pp. 302-8, Sept. 1984. (D)

[397] H.C. Patangia, "Stray free switched capacitor unity delay circuit," Electron. Lett., vol. 20, no. 20, pp. 844, Sept. 1984. (H)

[398] J.T. Taylor and J. Mavor, "Exact design of high pass switched capacitor filters of the LDI type," Electron. Lett., vol. 20, no. 20, pp. 839-41, Sept. 1984. (D)

[399] E. Sanchez-Sinencio and P.E. Allen, "Switched capacitor filter with partial passive feedback," Arch. Electron. \& Uebert, vol. 38, no. 5, pp. 331-9, Oct. 1984. (D)

[400] D. Bruckmann, "Design of VIS-SC filter with simulating reference filters in lattice structure," Arch. Electron. \& Uebert, vol. 38, no. 5, pp. 327-30, Oct. 1984. (D)

[401] E. Sanchez-Sinencio, J. Silva-Martinez and R.L. Geiger, "Biquadratic SC filter with small gain bandwidth effects," IEEE Trans Circuits \& Syst. vol. 31, no. 10, pp. 874, Oct. 1984. (D)

[402] U. Bernhardt, "Noise in switched capacitor integrator," Nachrichten. Elektronik, vol. 34, no. 10, pp. 390-3, Oct. 1984. (D)

[403] S.C. Fang, Y.P. Tsividis and O. Wing, "Space charge formulation of switched-capacitor networks containing nonlinear and time varying elements," IEEE Trans. Circuits \& Syst., vol. 31, no. 11, pp. 968, Nov. 1984. (A)

[404] S.L. Farhi, "Method for analysis of SC circuit with two phase symmetric communication," Elektroprom-st \& priborostr, vol. 19, no. 06, pp. 6-12, Nov. 1984. (A)

[405] A. Liberatore and S. Manetti, "Switched capacitor and their uses in modern integrated circuit," Electro, Technica, vol. 71, no. 11, pp. 1031-41, Nov. 1984. (A) 
[406] E. Sanchez-Sinencio, R.L. Geiger and J. Silva-Martinez, "Tradeoffs between passive sensitivity, output-voltage swing and total capacitance in biquadratic SC filters," IEEE Trans. Circuits \& Syst. vol. 31, no. 11, pp. 484-7, Nov. 1984. (D)

[407] S.O. Wski, "Synthesis of voltage transfer matrix using universal building blocks," Int. J. Electron., vol. 57, no. 5, pp. 685, Nov. 1984. (A)

[408] H. Friedberg, "Switched capacitor unit for analogue signal processing," Elektron. Ind., vol. 15, no. 11, pp. 98, Nov. 1984. (H)

[409] H.M. Yassine, "Four first order switched capacitor circuits," Electron. Lett., vol. 20, no. 24, pp. 1023-4, Nov. 1984. (D)

[410] E.V. Fudim, "Fundamental of the switched capacitor approach to circuit design," IEEE circuits \& systems Mag., vol. 16, no.4, pp. 12-21, Dec. 1984. (A)

[411] S.N. Shen, "An integrator model for analysis of switched capacitor filters," IEEE Int. conf. on computer-aided Design, Santa Calara, pp. 18-20, Nov. 1984. (D)

[412] M. Nagehban-Hag and Shu-Park Chan, "Signal flow graph analysis of switched capacitor filters," Conf. Record Eighteenth Asilomar conf. on circuits, systems and computers, Pacific Grove, pp. 125-9, Nov. 1984. (D)

[413] C.I. Mobbs, "Microwave switched bank," IEE Colloquium on Manipulating Micro Signals (Digest No-08) London England pp. 3/1-5, Dec. 1984. (H)

[414] C. Caillon and J. Guyot, "Monolithic switched capacitor filter using a prediffused technique," Rev. Tech. Thomson-CSF, vol. 16, no. 5, pp. 713-36, Dec. 1984. (D)

[415] F. Maloberti and G. Palmisano, "Four quadrants switched capacitor analog multiplier," Altra. Freq., vol. 53, no. 6, pp. 328-33, Dec. 1984. (H)

[416] N. Goto, M. Nishio and T. Suzuki, "A current-conveyor II realized by MOSFET, and its application to switched capacitor filters," Trans Inst. Electron. \& Communi. Engg. vol. J67C, no. 12, pp. 935-40, Dec. 1984. (D)

[417] C.A. Lish, "A Z-plane lerner switched capacitor filter," IEEE J. Solid State Circuits, vol. 19, no: 6, pp. 888-92, Dec. 1984. (D)

[418] A. Dela Plaza, "Power supply rejection in differential switched capacitor filter," IEEE J. Solid State Circuits, vol. 19, no. 6, pp. 912-18, Dec. 1984. (D)

[419] R.P. Colbeek, "A CMOS low distortion switched capacitor oscillator with instantaneous start up," IEEE J. Solid State Circuits, vol. 19, no. 6, pp. 996-8, Dec. 1984. (C)

[420] K. Watanable and G.C. Temes. "A switched capacitor digital bridge," IEEE Trans Instrum. \& Res., vol. 33, no. 4, pp. 247-31, Dec. 1984. (H)

[421] G. Holman, "SC techniques give seep filter on one chip," Eltekaktuell Electron., no. 15, pp. 49, Dec. 1984. (H)

[422] Y. Yoshida, Y. Marahara and H. Kawabara, "An automatics filters using switched-capacitor performance as an automatic equalizer at low $\mathrm{S} / \mathrm{N}$," Trans IECE, vol. J67B, no. 8, pp. 845-52, August 1984. (H)

[423] L. Toth, “Analysis of SC filters,” Hiradastechnika., vol 35, no. 7, pp. 324, Dec. 1984. (D)

[424] R. Bradrarov, T. Koujoumelijiv and G. Babinow, "General matrix analysis of switched capacitor networks," Tekh. Misul., vol. 21, no. 1, pp. 29-34, Dec. 1984. (A) 
[425] J.J. Mulawka and A. Pakulak, "Switched capacitor implementation of phase locked loops," IEE Proc. G., vol. 131, no. 6, pp. 221-5, Dec. 1984. (H)

1985

[426] H. Unger and K. Preiser, "Noise investigation on integrated SC amplifier," Nachrichten. Electronik, vol. 35, no. 10, pp. 382-4, Jan. 1985. (B)

[427] G.M. Jacob, "All pass biquadratic switched capacitor filter," IEEE Trans. Circuits \& Syst., vol. 32, no. 1, pp. 1-12, Jan. 1985. (D)

[428] D. Bruckman, "Design of switched capacitor elements with voltage inverter switches for simulation of FDNR reference structure," Int. J. Circuit Theory \& Appl., vol. 13, no. 1, pp. 19-35, Jan. 1985. (F)

[429] L.G. Guang-Pu and S. Zhi-Guang, "Analysis design of switched capacitor networks (SCN) based switched capacitor for micro models," IEEE Trans Circuits \& Syst., vol. 31, no. 1, pp. 12-9, Jan. 1985.

[430] V.I. Georgiev, "Integrator with commutable capacitors. (switched-capacitor networks.)," Electro. Prom-St \& Priborostr, vol. 20, no. 7, pp. 20-4, 1985 (B)

[431] Gu Qunshan and Wang Wenxuan. "New realization of unit element wave switched capacitor," J. Electron., vol. 7, no. 4, pp. 263, Jan. 1985. (A)

[432] H. Baher, "Synthesis of high pass switched capacitor LDI filter," Electron. Lett., vol. 21, no. 2, pp. 79-80, Jan. 1985. (D)

[433] A.E. Said, "Stray free switched capacitor building block that realize delay constant multiplier or summer circuit," Electron. Lett., vol. 21, no. 4, pp. 167-8, Feb. 1985. (A)

[434] H.G. Dimopoulos, "New switched capacitor ladder filters," Electron. Lett., vol. 2, no. 4, pp. 152-4, Feb. 1985. (D)

[435] F. Montecchi, "Low pass to high pass transformation in VIS switched capacitor filters," Electron. Lett., vol. 21, no. 4, pp. 152-4, Jan. 1985. (D)

[436] R. Castello and 'P.R. Gray, "A 350uw fifth-order low pass switched-capacitor filters," New York, USA, pp. 13-15, Feb. 1985. (D)

[437] E.I. EI-Masry, "Synthesis of a follow the ladder feedback switched capacitor structure," IEE, Proc. G, vol. 132, no. 1, pp. 18-23, Feb. 1985. (A)

[438] S. Fushimi and K. Nakayama, "A discrete optimization method of switched-capacitor filters," Electron. \& Communi. Jpn. Part. 1, vol. 68, no. 2, pp. 40-9, Feb. 1985. (D)

[439] K. Matsui, T. Matsuura, S. Fukasawa and Y. Fzawa, "CMOS video filter using switched capacitor $14 \mathrm{~Hz}$ circuits," 1985 IEEE Int. solid state circuits conf., 32nd ISSCC Digest of Technical paper New York, USA, pp. 282-3, Feb. 1985. (D)

[440] D.R. Ribner, M.A. Copeland and M. Micovic, "15Hz CMOS switched capacitor filters," 1985 IEEE Int. solid state circuits conf. 32nd ISSCC Digest of Technical paper, New York, pp. 284-5, Feb. 1985. (D)

[441] M.E.A. Aboce-eisoud and N.A. Ralson, "Designing technique for a FET switched capacitor resistor filter," Tech. Res. Centre of a France, Cario Egypt Mill. Tech. Coll. 1985. (D) 
[442] J.L. Sanza and F. Cobian, "Switched capacitor filter: an updated report," Munde Electron., no. 149, pp. 117-24, March 1985. (D)

[443] J.L. Huertas, A. Rodriquez-vazgue, and B. Perez-verdu, "A novel SC oscillator," IEEE Trans. Circuits \& Syst., vol. 31, no. 3, pp. 310-12, March 1985. (C)

[444] S. Eriksson, "First order SC filter section interpolation output," Electron. Lett., vol. 21, no. 6, pp. 221-222, March 1985. (D)

[445] A.O. Adam, O.E. Agazzi and J.D. Britos, "Switched capacitor filters sampling integrators," Rev. Telegr. Electron., vol. 73, no. 173-6, March 1985. (D)

[446] A.O. Adam, O.E. Agazzi and J.D. Britos, "Switched capacitor filters implementation in MOS technology and technological limit," Rev. Telegr. Electron., vol. 73, no. 862, pp. 457-60, March 1985. (D)

[447] T. Takabe and H. Kunicda, "An overview on analysis and design of switched capacitor circuit," J. Inst. Electron. \& Communi. Engg. vol. 68, no. 3, pp. 284-9, March 1985. (A)

[448] K. Chen and S. Eriksson, "Design of parasitic insensitive for phase wave SC filters," IEE Proc. G, vol. 132, no. 2, pp. 46-52, March 1985. (D)

[449] D.C. Von Gruenigen, "An introduction to switched capacitor filters," Bull ASSOC Suiss Electr., vol. 72, no. 7, pp. 367-71, April 1985. (D)

[450] O.E. Agazzi, A.O. Adan and J.D. Britos, "Switched capacitor filters design," Rev. Telegr. Electron., vol. 73, no. 861, pp. 315-19, April 1985. (D)

[451] G. Fischer and G.S. Moschytz, "Highly selective SC filter for high frequency applications," IEEE Int. Symp. on Circuits and Systems, Proc., New York, pp. 785-8, vol. 2, April 1985. (D)

[452] F. Maloberti and F. Montecchi, "Low frequency noise reduction in the shaved switched capacitor ladder filter," IEE Proc. G, vol. 132, no. 2, pp. 39-45, April 1985. (D)

[453] R. Priemer, "Switched capacitor D/A converter," Research Triangle Park NCISA, pp. 939-43, April 1985. (G)

[454] C.A. Halijak and A. Davari, "Sample consequence of the finite time laplace transform analysis of the periodically reversed switched capacitor," Circuits, systems and signal processing, vol. 4, no. 4, pp. 503-15, May $1985(\mathrm{H})$

[455] C. Caillon, J.P. Roche and C. Tirrior, "Switched capacitor CMOS monolithic filter, a new concept," Thomson Semicond., vol. 65, no. 3, pp. 7-19, May 1985. (D)

[456] A. Kumar and S.K. Saha, "Switched capacitor using unity gain amplifier," Int. J. Electron., vol. 58, no. 5, pp. 875-8, May 1985. (B)

[457] G. Fischer, "Monolithic IF filter using SC techniques," Mitt. Agen., no. 40, P. 17-29, May 1985. (D)

[458] M. Hasler, M. Saghafi, "Stray capacitance elimination of switched capacitor circuits," Mitt. Agen., no. 40, P. 9-16, May 1985. (D)

[459] C. Canosi, A. Colamonico, M. Donati and F. Maloberti, "Switched capacitor filters for a 1200 band fsk modem," Ann Telecommuni., vol. 40, no. 5-6, pp. 235-42, May 1985. (D)

[460] J.M. Worley, "Switched capacitor realization of wide band phase spliting 
networks," 4th Australian Microelectronics conf., Migrating to silicon, Sydney, NSW Australia, pp. 209-16, May 1985. (A)

[461] C.S. Lie and G.A. Righy, "High-speed NMOS switched capacitor filter," 4th Australian Microelectronics Conf, Migrating to silicon, NSW Australia, pp. 79-85, May 1985. (D)

[462] T. Inoue, F. Ueno, K. Tegami and S. Masuda, "Low sensitive leapfrog switched capacitor filters using differential mode building blocks," 1985 Int. symp. on circuits and systems, Proc. Kyoto, Japan, vol. 2, pp. 543-42, June 1985. (D)

[463] J.T. Taylor and J. Mavor, "Exact design of lowpass and high pass ladder filters from unit element prototype," Int. symp. on circuits and systems, proc. Kyoto, vol. 2, pp. 543-6, June 1985. (D)

[464] M. Kanako and M. Onoda, "New signal flow representation of switched capacitor networks and application to stray insensitive design," 1985 Int. symp. on circuits \& systems, proc. Kyoto, vol. 1, no. 33-6, June 1985 (H)

[465] M.S. Tawtik, G. Mazare and P. Senn, "On the relationship between, LDI and bilinear switched capacitor ladder filters," 1985 Int. symp. on circuits and systems. Proc. Kyoto, vol. 2, pp. 527-30, June 1985. (D)

[465] F. Montecchi, "Bilinear design of high pass switched capacitor ladder filter," 1985 Int. symp. on circuits and systems. Proc. Kyoto, Japan, pp. 547-50, June 1985. (D)

[466] P.R. Gray and R. Castello, "Performance limitations in switched capacitor filters," 1985 Int. symp. on circuits and systems. Proceeding Kyoto, Japan, vol. 1, pp. 247-50, June 1985. (D)

[467] K. Chen and S. Eriksson, "Wave SC filters with reduced number amplifiers," Int. symp. on circuits and systems. Proc. Kyoto, vol. 2, pp. 5511-4, June 1985. (D)

[468] W. Sansen, P.M. Van Peteghem and N. Steyaert, "Switched capacitor filters for biomedical signal processing," 1985 Int. symp. on circuits and systems. Proc. Kyoto, Japan, vol. 1, pp. 243-6, June 1985. (D)

[469] K. Nagraj, "A novel switched capacitor rectifier," Int. J. Electron, vol. 58, no. 6, pp. 997-1002, June $1985(\mathrm{H})$

[470] T. Inoue and F. Ueno, "On robustness of the stability of multi phase switched capacitor two phase," IEEE Trans Circuits \& Syst., vol. 32, no. 6, pp. 522-2, June 1985. (D)

[471] G.A. Somlka, "Synthesis of switched capacitor circuits simulating canonical reactance section," IEEE Trans. Circuits \& Syst., vol. 32, no. 6, pp. 513-21, June 1985. (F)

[472] S. Pei and R. Liu, "Optimum design of cascade switched capacitor building blocks by linear programming," 1985 Int. symp. on circuits and systems. Proc. Kyoto, vol. 2, pp. 781-4, June 1985. (A)

[473] S.M. Faruque, "Layout automation in switched capacitor filter," 1985 Int. symp. on circuits and systems. Proceeding Kyoto, Japan, vol. 2, pp. 770-80, June 1985. (D)

[474] K. Leea and S. Park, "Analysis of switched-capacitor networks by reduced modified nodal approach," 1985 Int. symp. on circuits and systems. Proceeding Kyoto, Japan, vol. 3, pp. 1155-8, June 1985. (A)

[475] T. Inoue, F. Ueno, K. Tagami and S. Masuda, "Low sensitivity leapfrog 
switched capacitor filters using differential mode building blocks," 1985 Int. symp. on circuits and systems. Proc. Kyoto, vol. 2, pp. 539-42, June 1985. (D)

[476] C.K. Pun and J.I. Sewell, "Symbolic analysis of ideal and nonideal switched capacitor networks," 1985 Int. symp. on circuits and systems. Proc. Kyoto, vol. 3, pp. 1165-8, June 1985. (A)

[477] J.J. Mulawka, "Synthesis of switched capacitor networks in the p-domain," 1985 Int. symp. on circuits and systems. Proceeding Kyoto, Japan, pp. 535-8, June 1985. (A)

[478] D.B. Ribner and M.A. Copeland, "Computer-aided analysis of nonideal linear switched capacitor networks for high frequency application," Int. symp. on circuits and systems. Proc. Kyoto, Japan, vol. 3, pp. 1169-72, June 1985. (A)

[479] J.E. Da. Franca, "A single-path frequency-translated switched capacitor system for filtering and single side band generation and detection," 1985 Int. symp. on circuits and systems. Proc. Kyoto, Japan, vol. 3, pp. 1625-8, June 1985. (D)

[480] H. Onodera and K. Tamaru, "A cyclic analog to digital converter using switched capacitor integrator," 1985 Int. symp. on circuits and systems, Proc. Kyoto, vol. 1, pp. 333-6, June 1985. (G)

[481] T. Takebe, "Switched-capacitor variable attenuation equalizer," 1985 Int. symp. on circuits and systems. Proceeding Kyoto, Japan vol. 3, pp. 1633, June 1985. (H)

[482] P.E. Fleischer and K.R. Laker, "Design of balanced switched capacitor biquad," 1985 Int. symp. on circuits and systems. Proceeding Kyoto, Japan, vol. 2, pp. 769-72, June 1985. (D)

[483] J.C.M. Bermudez and B.B. Battacharyya, "Generation, classification and design of single OA SC networks," 1985 Int. symp. on circuits and systems. Proc. Kyoto, Japan, vol. 2, pp. 773-6, June 1985. (A)

[484] H. Seki and S. Mori, "Analog to digital and digital to analog converters using switched capacitor amplifier," 1985 Int. symp. on circuits and systems. Proc. Kyoto, Japan, vol. 1, pp. 337-40, June 1985. (G)

[485] E. Sanchez-Sinencio and J. Silva-Martinez, "Second order programmable switched-capacitor filters," 1985 Int. symp. on circuits and systems. Proceeding Kyoto, Japan, vol. 1, pp. 1617-20, June 1985. (D)

[486] M. Ishikawa, "Low sensitivity switched-capacitor integrator with differential mode," 1985 Int. symp. on circuits and systems. Proceeding Kyoto, Japan, vol. 2, pp. 767-8, June 1985. (B)

[487] K. Watanable and H. Matsumoto, "Switched capacitor algorithmic digitalto-analog and analog to digital converters," 1985 Int. symp. on circuits and systems. Proceeding Kyoto, Japan, pp. 331-2, vol. 1, June 1985. (G)

[488] M. Kakizaki and T. Sugawara, "An efficient numerical analysis method for small signal frequency response of periodically operating circuits," 1985 Int. symp. on circuits and systems. Proc. Kyoto, vol. 2, pp. 579-82, June 1985. (A)

[489] M. Vlach, K. Singhal, R. Chadha and E. Christen, "WATSCAD-A, program for the analysis and design of switched capacitor networks," 1985 Int. symp. on circuits and systems. Proceeding Kyoto, Japan, June 1985. (A)

[490] A.M. Davis, "Wave variable analysis of passive switched capacitor circuits," 1985 Int. symp. on circuits and systems. Proceeding Kyoto, Japan, pp. 11614, vol. 3, June 1985. (A) 
[491] J.A. Hegst, "An immittance converter for switched capacitor filter synthesis," 1985 Int. symp. on circuits and systems. Proceeding Kyoto, Japan, pp. 785-8, vol. 2, June 1985. (D)

[492] G.R. Shapiro, "FIR switched-capacitor modulator for discrete QAM," 1985 Int. symp. on circuits and systems. Proceeding Kyoto, Japan, pp. 1629-32, vol. 3, June 1985. (H)

[493] J. Vlach and E. Christen, "Sensitivities of poles and zeros in switchedcapacitor circuits," 1985 Int. symp. on circuits and systems. Proceeding Kyoto, Japan, vol. 3, pp. 1159-60, June 1985. (H)

[494] E.P. Rudd and R. Schaumann, "A program for the analysis of high frequency behavior of switched capacitor networks," 1985 Int. symp. on circuits and systems. Proceeding Kyoto, Japan, pp. 1173-6, vol. 3, June 1985. (A)

[495] D. Bruckman, "Novel voltage inverter switches with minimum sensibility properties," IEEE Trans Circuits \& Syst., vol. 32, no. 7, pp. 723-6, July 1985. (H)

[496] A.M. Davis, "Flow graph synthesis of darlington causer switched capacitor filters," IEEE Trans Circuits \& Syst. vol. 32, no. 7, pp. 727-32, July 1985. (D)

[497] K.R. Laker, A. Ganesan and P.E. Fleischer, "Design and implementation of cascade switched capacitor delay equalizers," IEEE Trans Circuits \& Syst. vol. 32 , no. 7 , pp. 700-11, July 1985 . (H)

[498] P.V. Anand Mohan, "Computer aided design of stray insensitive switched capacitor filters," Electron. Lett., vol. 21, no. 14, pp. 588-9, July 1985. (D)

[499] F. Baillien and R. Hermel, "CMOS amplifier in switched capacitor circuit," Rev, Phy, Appl., vol. 20, no. 7, pp. 465, July 1985. (B)

[500] Zha Qiang-zhong. "Exact design of filters using signals flow graphs and two integrators loops," Acta. Electron. Sin, vol. 13, no. 4, pp. 64-71, July 1985. (D)

[501] A.O. Adam and O.E. Agazzi, "Design of a data transmission filter for minimum interference between symbols, based on switched capacitor," Rev. Telegr. Electron., vol. 73, no. 864, pp. 724-7, July 1985. (D)

[502] S. Masuda, "Low sensitivity leapfrog switched-capacitor filters using differential blocks," Trans. Inst. Electron. \& Communi. Eng. Jpn. Sect. E. vol. 68, no. 7, pp. 456-63, July 1985 . (D)

[503] J. Mavor, "Exact design of high pass switched capacitor filter of LDI type," Electron. Lett., vol. 21, no. 15, pp. 643, July 1985. (D)

[504]K. Nagraj, K. Singhal, T.R. Viswanathan and J. Vlach. "Reduction of finite gain effect in switched capacitor filter," Electron. Lett., vol. 2, no. 15, pp. 644-5, July 1985 . (D)

[505] C. Calion, J.P. Roche and C. Terrier, "Mask programmable filters, a new concepts for monolithic switched capacitor filters," IEEE Trans Consum. Electron., vol. 31, no. 3, pp. 456-60, August 1985. (D)

[506] A.O. Adam and O.E. Agazzi, "Using switched-capacitor techniques to design a data transmission filter with minimum inter symbol interference," Rev. Telegr. Electron., vol. 73, no. 865, pp. 872-5, August 1985. (D)

[507] P.M. Van Peteghem, I. Verbanwhede and W.M.C. Sansen, "Micro power high performance SC building block for integrator low level signal processing," IEEE J Solid State Circuits, vol. 20, no. 4, pp. 837-44, August 1985. (B) 
[508] J.C.M. Bermudez and B.B. Battacharyya, "A symmetric procedure for generation and design of parasitic insensitive SC biquads," IEEE Trans Circuits \& Syst., vol. 32, no. 8, pp. 761-83, August 1985. (D)

[509] G. Fischer and G.S. Moschytz, "SC leapfrog filters without additional adder stages," IEEE Trans Circuits \& Syst. vol. 32, no. 8, pp. 853, August 1985. (D)

[510] P.V. Anand Mohan, V. Ramchandran and M.N.S. Sawami, "A novel two amplifiers universal active switched capacitor filters," Proc. IEEE, vol. 73, no. 8, pp. 1330, August 1985. (D)

[511] M. Ismail and T. Bacon, "New approach to synthesis of switched capacitor filters in the Z-domain," Conference proceeding 28th Midwest symp. on circuits and systems, Louisville, pp. 38, 6-9, August 1985. (D)

[512] A.M. Davis and R.R. Smith, "Polynomial transform synthesis of state variable switched capacitor filters," Conference proceeding 28th Midwest symp. on circuits and systems, Louisville, pp. 800-4, August 1985. (D)

[513] K. Nagraj, K. Singhal, T.R. Viswanathan and J. Vlach, "Techniques for reducing the finite gain effect in switched capacitor circuit," Conference proceeding 28th Midwest symp. on circuits and systems, Louisville, pp. 637-41 August 1985. (H)

[514] E.I. EI-Masry and, H. Lee, "A generalized multi loop feedback switched capacitor structure," Conference proceeding 28th Midwest symp. on circuits and systems, Louisville, pp. 616-20, August 1985. (A)

[515] A.E. Said and M.E. Zaghloul, "Stray free switched capacitor general biquad blocks," Conference proceeding Midwest symp. on circuits and systems, Lousivlle, pp. 625-8, August 1985. (D)

[516] A.D. Meakin, J.I. Sewell and L.B. Wolovitz, "Techniques for improving the efficiency analysis software for large switched capacitor networks," Conference proceeding 28th symp. on circuits and systems, Louisville, pp. 390-3, August 1985. (A)

[517] G.W. Roberts, W.M. Senelgrove and A.S. Sedra, "Switched capacitor realization of nth order transfer function using a single multiplexed op amp," Conference Proceeding 28th Midwest Symp. on circuits and systems, Louisville, pp. 633. August 1985. (D)

[518] T. Suzuki and S. Kadowoki, "Synthesis of single amplifier switched capacitor filters," Trans. IECE, vol J68A no. 9 pp. 986-6, Sept. 1985 (D)

[519] J. Mikula, "An economic connection of inductors with switched capacitor," Slaboproudy Obz, vol. 46, no. 9, pp. 448-30, Sept. 1985. (F)

[520] P. Moos and T. Dostal, "Energy and power in a network loop with a switched capacitor," Slaboproudy Obz, vol. 46, no. 9, pp. 454-6, Sept. 1985. (H)

[521] F. Ueno and T. Inoue, "Effect of parasitic inductances on properties of switched capacitor power supplies," Trans. Inst. Electron. \& Communi. Engg. vol. 68C, no. 9, pp. 779-80, Sept. 1985. (H)

[522] A.M. Davis, "Wave variable analysis of passive switched capacitor circuits," IEEE Trans Circuits \& Syst. vol. 32, no. 9, pp. 935, Sept. 1985. (D)

[523] J. Pandel, "Reduction of capacitances ratios in switched capacitor filters employing voltage inverter switches," AEU, vol. 39, no. 5, pp. 306-10, Sept. 1985. (D) 
[524] J.E. Da Franca, "A single path frequency translated band pass filter system," IEEE Trans Circuits \& Syst., vol. 32, no. 9, pp. 938, Sept. 1985. (D)

[525] Mim Ho Choi and Do Hyun Kim "A study on compensation of frequency distortion of SCF by using prewaping procedure," J. Korea Inst. Electron. Engg. vol. 22 , no. 5 , pp. $69-74$, Sept. 1985. (D)

[526] J.E.Da. Franca, "Nonrecursive polyphase switched capacitor decimators and interpolators," IEEE Trans. Circuits \& Syst., vol. 32, no. 9, pp. 938-49, Sept. 1985. (H)

[527] R. Castello and P.R. Gray, "Performance limitation of switched-capacitor filters," IEEE Trans Circuits \& Syst., vol. 32, no. 9, pp. 865-70, Sept. 1985 (D)

[528] A.G. Hall, "Correlation and aliasing in the noise cancelling switchedcapacitor filtering technique," Electron. Lett., vol. 21, no. 20, pp. 932, Sept. 1985. (D)

[529] G.A. Nenov and T.G. Kouyoumdjiev, "Synthesis of total capacitance minimized stray insensitive high order SC filters," Circuit theory and design 85. Proc. of the European conf. Prague, Czechoslovakia, pp. 769-72, Sept. 1985. (D)

[530] U. Kleine, D. Beuckmann and B.J. Hosticka, "Wave switched capacitor filters with reference filters using lattice structures," Circuit theory and design 85. Proc. of the European conf. Prague, pp. 733-6, Sept. 1985. (D)

[531] J.E. Franca, "On switched capacitor band pass filter systems with very narrow relative bandwidths," Circuit theory and design 85. Proc. of the European conf. Prague, Czechoslovakia, pp. 745-8, Sept. 1985. (D)

[532] T. Fulop, "Transient behavior of switched capacitor integrator," Circuit theory and design 85. Proc. of the European conf. Prague, Czechoslovakia, pp. 717-40, Sept. 1985. (B)

[533] A. Handkiewicz, "Switched capacitor network synthesis by extraction procedure," Circuit theory and design 85. Proc. of the European conf. Prague, Czechoslovakia, pp. 737-40, Sept. 1985. (A)

[534] A. Puerta and J. Mamir, "Synthesis of switched capacitor networks by two frequency transformations," Circuit theory and design 85. Proc. of the European conf. Prague, Czechoslovakia, pp. 721-4, Sept. 1985. (A)

[535] P. Moos, M. Trezzi and M. Vlach, "On the modulation process in SC structure," Circuit theory and design 85. Proc. of the European conf. Prague, Czechoslovakia, pp. 749-52, Sept. 1985. (H)

[536] P. Van Peteghem and W. Sansen, "Clock feed through in switched capacity circuits," Circuit theory and design 85. Proc. of the European conf. Prague, Czechoslovakia, pp. 753-6, Sept. 1985. (H)

[537] L. Toth, A. Vitalyo, G. Kalvach and E. Simonyl, "Noise analysis of ideal and lossy switched capacitor networks," Circuit theory and design 85. Proc. of the European conf. Prague, Czechoslovakia, pp. 773-6, Sept. 1985. (B)

[538] D.J. Gillbert and J.I. Sewell, "On the generalized equivalent switched capacitor networks," Circuits theory and design 85. Proc. of the European conf. Prague, Czechoslovakia, pp. 697-700, Sept. 1985 (A)

[539] P. Moos and P. Martinek, "Synthesis of switched capacitor filter with generalized converters," Circuit theory and design 85, proc. of the European Conf. Prague, Czechoslovakia, pp. 741-7, Sept. 1985. (D) 
[540] S.L. Frachy, N.A. Radev and K.P. Stantchev, "The influence of the nonideality of op amp on the frequency response of the two phase clock switched capacitor biquads," Circuit theory and design 85. Proc. of the European conf. Prague, Czechoslovakia, pp. 784-7, Sept. 1985. (D)

[541] R.S. Soin, J.B. Hughes and N.C. Bird, "A novel approach to the time domain simulation of switched capacitor systems," Circuit theory and design 85 . Proc. of the European conf. Prague, Czechoslovakia, pp. 713-6, Sept. 1985. (A)

[542] J.J. Mulawka and M. Nahecz, "Design of strays insensitive switched capacitor two ports," Circuit theory and design 85. Proc. of the European conf. Prague, Czechoslovakia, pp. 765-8, Sept. 1985. (A)

[543] M. Balko and S. Icrawezyk, "Influence of nonlinear switched resistance on nonlinear distortions in switched capacitor circuits," Circuit theory and design 85. Proc. of the European conf. Prague, Czechoslovakia, pp. 780-19, Sept. 1985. (A)

[544] T. Poreczi, "Fast analysis of active switched capacitor filters," Circuit theory and design 85. Proc. of the European conf. Prague, Czechoslovakia, pp. 709-19, Sept. 1985. (D)

[545] M. Haster and M. Saghafi, "Switched capacitor filters with a row dominant nodal admittance matrix," Circuit theory and design 85. Proc. of the European conf. Prague, Czechoslovakia, pp. 729-32, 1985. (D)

[546] A. Rodriguez-vazquez and J.L. Huertas, "On a class of SC resistors and its application to the synthesis of nonlinear driving point and transfer function plots," Int. J. Circuit Theory \& Appl., vol. 13, no. 4, pp. 309-26, Oct. 1985. (H)

[547] O. Leenhardt, "New idea in filtering, mask programmable switched capacitor," Electron. Ind., no. 92, pp. 53-6, Oct. 1985. (D)

[548] A. Cichocki and R. Unbehanen, "Design of precision switched capacitor integrators and their applications to the synthesis of nonlinear networks," IEE Proc. G, vol. 32, no. 5, pp. 225-36, Oct. 1985. (B)

[549] A. Rodriquez-vazquez, J.L. Huertas and L.O. Chua, "Chaos in switched capacitor circuits," IEEE.Trans. Circuits \& Syst., vol. 32, no. 10, pp. 1083-5, Oct. 1985. (H)

[550] J.S. Brar, J.V. Hanson and T.R. Viswanathan, "Switched capacitor implementation of a Hillbert transform," Proceeding of MELECON'85 Meliterranean Electrotechnical conference, Madrid, Spain, pp. 7-9, Oct. 1985. (H)

[551] M. Milic, "Some methods of analyzing switched capacitor networks," Tehnika, vol. 40, no. 7-8, pp. 1201-14, Oct. 1985. (A)

[552] R. Palomera-garcia and A. Reyes-serro, "On the loop equation formulation of switched capacitor networks," Int. J. Circuit Theory \& appl., vol. 13, no. 4, pp. 362-6, Oct. 1985. (A)

[553] G.A. Nenov and T.G. Kouyoumdjiev, "A signal-flow-graph approach to the synthesis of stray insensitive high order SC filters," Proceeding of MELECON'85 Meliterranean Electrotechnical conference, Madrid, Spain, vol. 2, pp. 1-4, Oct. 1985. (D)

[554] A. Castello and W. Warzanskyj, "Switched capacitor filter banks using multi rate techniques," Proceeding of MELECON'85, Meliterranean Electrotechnical conference, Madrid, Spain pp. 27-30, vol. 2, Oct. 1985. (D) 
[555] M. Kravss, "Implementation of capacitors in integrated switched capacitor. op amp circuits," Wiss. Z. Tech Univ. Dresden., vol-34, no. 4, pp. 131-8, Oct. 1985. (B)

[556] M.N.A.S. Nessar, "Switched capacitor ladder filter simulation using frequency domain analysis," Proceeding of MELECON'85, Meliterranean Electrotechnical conference, Madrid, Spain, pp. 3-77, vol. 3, Oct. 1985. (D)

[557] J. Robert, G.C. Temes, F. Krummenacher, V. Valencie and P. Devel, "Offset and clock feed through compensated switched capacitor integrators," Electron. Lett., vol. 21 , no. 21 , pp. 1000, Oct. 1985. (B)

[558] T. Ono, "C-spread switched capacitor inductance simulation circuits," Trans. Inst. Electron. \& Communi. Engg. Jpn. Part. A, vol. J68A, no. 10, pp. 1135, Oct. 1985. (F)

[559] T. Inoue and F. Ueno, "Switched capacitor ladder filters with zero worstcase sensitivity at reflection zeros," Electron. Lett., vol. 21, no.21, pp. 10002-3, Oct. 1985. (D)

[560] A. Puerta, J.M. Miro and M. Sanz, "Computer based frequency analysis of switched capacitor circuits," Mundo, Electron., no. 155, pp. 41-5, Oct. 1985. (A)

[561] G.C. Temes and Teng-Hsienhsu, "An improved circuit for pseudo N-path switched capacitor filters," IEEE Trans Circuits and systems, vol. 32, no. 10, pp. 11071, Oct. 1985. (A)

[562] J. Robert, G.C. Temes, F. Krummenacher and J. Vlach, "Offset and clock feed through compensated switched capacitor integrator," Electron., Lett., vol. 21 , no. 21 , pp. 1000-1, Oct. 1985. (B)

[563] G. Fischer and G.S. Moschytz, "Switched capacitor filter for high frequency compensation for finite gain amplifier," IEEE Trans Circuits and systems, vol. 32, no. 10 , pp. 1050 , Oct. 1985 . (D)

[564] A. Cichocki and R. Unbehauen, "Design of precision switched-capacitor and their application to the synthesis of nonlinear networks," IEE Proc. G. vol. 32 , no. 5 , pp. 225-36, Oct. 1985 . (A)

[565] Y.P. Tsividis, "Time and frequency domain analysis of linear switched capacitor networks using state charge variable," IEEE Trans. CAD Integrated Circuits \& Syst., vol. 4, no. 4, pp 651. Oct. 1985. (A)

[566] I. Sasaki, K. Okabe and S. Yoneda, "SC realization of Fourier analyzer using integrator feedback capacitance circuits," Oct. 1985. (B)

[567] W.C. Black, "Floating integrator technique for switched capacitor circuit employing reset cycles," Electron. Lett., vol. 21, no. 24, pp. 1126-8, Oct. 1985. (A)

[568] S. Eriksson, "Offset compensated bilinear SC filter of leapfrog type using a two phase clocks," Electron. Lett., vol. 21, no. 22, pp. 1043-4, Oct. 1985. (D)

[569] M. Kaneka and M. Onoda, "A signal flow-graph representation for switched capacitor networks and its application to SC circuit," Trans. IECE vol. J68A, no. 11, pp. 66-74, Nov. 1985. (A)

[570] G. Fischer, "Monolithic SC IF filters," Bull. ASSOC. Suise Electron., vol. 76, no. 21 , pp. 1263-71, Nov. 1985. (D)

[571] K. Hang and G.C. Temes, "Switched capacitor integrator with low finite gain sensitive," Electron. Lett., vol. 21, no. 24, pp. 1156, Nov. 1985. (A) 
[572] T. Lane, "A low pass switched-capacitor filter the best of both worlds," New Electron., vol. 18, no. 23, pp. 43-2, Nov. 1985. (D)

[573] A. Kumar and S.K. Saha, "Switched capacitor high pass and band pass filter using unity gain amplifiers," J. Inst. Electron. \& Telecommuni. Engg., vol. 31, no. 6, pp. 190-2, Nov. 1985. (D)

[574] H. Bacher, "Analysis and design of constant delay switched-capacitor filters with amplifier selectivity," IEE Proc. G., vol. 132, no. 6 pp. 281-7, Dec. 1985. (D)

[575] J.J. Mulawka and G.S. Moschytz, "A by-inspection analysis of SC networks using direct topological rule," IEE Proc. G, vol. 132, no. 6, pp. 255-65, Dec. 1985. (A)

[576] Y. Horio and S. Mori, "Switched capacitor lossless discrete differential with modified sampled and hold sequence," Electron. Lett., vol. 21, no. 22, pp. 036-7, Dec. 1985. (H)

[577] H. Geher, "Analysis and synthesis of SC filters," Nachrichten. Elektronik, vol. 35, no. 6, pp. 224-7, Dec. 1985. (D)

[578] F.M. Maloberti, F. Montecchi and G. Torechi, "Bilinear design of fully differential SC ladder filters," IEE Proc. G, vol. 132, no. 6, pp. 266-72, Dec. 1985. (D)

[579] J. Mikula and T. Dostal, "A design approach to switched capacitor networks, using Mc graph," Slaboproudy Obz, vol. 46, no. 12, pp. 560-5, Dec. 1985. (A)

[580] T. Inoue, "Parasitic compensated fully differential switched capacitor integrator," Trans. Inst. Electron. \& Communi. Eng. Jpn. Sect. E. vol. 68, no. 12, pp. 798-9, Dec. 1985. (B)

1986

[581] E. Fehlauer and M. Kraus, "An efficient algorithm for the time domain analysis of switched capacitor op amp circuits," Wiss. Z. Tech. Dresden, vol. 35, no. 4 , pp. $159-63,1985$. (B)

[582] M. Krauss, "MOS analogue switch in integrated switched capacitor op amp," Wiss. Z. Tech. Dresden, vol. 35, no. 4, pp. 153-7, 1986. (B)

[583] M. Lamkerneuer, W. Brokherde, J. Buddefield, B.J. Hosticka and P. Richert, "Design and optimization switched capacitor noise sampling corders up to 4th order," NTZ-fachber, vol. 96, pp. 51-6, 1986. (H)

[584] Z. Tomoszewki, G. Trroter, J. Einspenner and P. Sieber, "Programmable switched capacitor filter for application specific uses," NTZ-fachber, vol. 96, pp. 303-8, 1986. (D)

[585] I. Chen and S. Eriksson, "Fully differential bilinear integrator for SC filters," Electron. Lett., vol. 22, no. 1, pp. 24-5, Jan. 1986. (D)

[586] D. Mc. Gee, "SC filters in CMOS". Electron. Engg., vol. 58, no. 709, pp. 63, Jan. 1986. (D)

[587] Y. Horio and S. Mori, "SC modify lossless discrete differentiator and resulting SC high pass ladder filters," Electron. Lett., vol. 22, no. 2, pp. 97-9. Jan. 1986. (D)

[588] K. Nagraj and K. Singhal, "High CMRR stray-insensitive switched ca- 
pacitor differential input stage for A/D converters," Electron. Lett., vol. 22, no. 1, pp. 50, Jan. 1986. (G)

[589] M. Ishikawa, "A synthesis of switched capacitor filter using voltage and charge variable," Trans. Inst. Electron. \& Communi. Engg. Japan vol. J69A, no. 2, pp. 15, Feb. 1986. (D)

[590] F. Ueno, T. Inoue and H. Iida, "Analysis of switched capacitor power supply using finite element method," Trans Inst. Electron. \& Communi. Engg. Part, C, vol. 69. no. 2, pp. 215-23, Feb. 1986. (H)

[591] Y. Jyo, M. Kamide, T. Otaki, S. Minamoto and Y. Kojima, "Voltage controlled switched capacitor oscillator," Trans. Inst. Electron. \& Communi. Engg., vol. 69, no. 2, pp. 227-9, Feb. 1986. (C)

[592] M. Ishikawa, "A synthesis of switched capacitor filter using voltage and charge variables," Trans. Inst. Electron. \& Communi. Engg. Part-A, vol. 69, no. 2, Feb. 1986. (D)

[593] J.A. Philips, S.J. Harrold and D.G. Haigh, "A GaAs switched capacitor band pass filter operating at a switching frequency of $250 \mathrm{MHz}$," IEE Colloquium on ICs above $1 \mathrm{GHz}$, Fabrication and circuit Design, London, pp. 15, vol. 2, March 1986. (D)

[594] M. Ishikawa, "Low sensitivity switched capacitor integrators," Trans Inst. Electron. \& Communi. Engg. Japan, vol. J69A, no. 3, pp. 367-73, March 1986. (B)

[595] Chang Won Sup and K. Watanable, "Switched-capacitor interface for intelligent capacitance transducers," Tep. Grand. Sch. Electron. Sci. \& Technol Shiruka Univ., no. 7, pp. 19-26. March 1986. (H)

[596] J.C. Lin and J.H. Nevin, "Fully differential stray-insensitivity bilinear-Z switched capacitor high pass filter," Electron. Lett., vol. 22, no. 7, pp. 378-9, March 1986. (D)

[597] P.V. Anand Mohan, "Novel second order active filter using resistor and switched capacitor simulated inductor and capacitance," AEU, vol. 40, no. 2, pp. 124-6, April 1986. (D)

[598] M.T. Sukahara and H. Ishikawa, "Switched resistor circuits realizing unequal valued resistor," Trans. Inst. Electron. \& Communi. Engg. Japan, vol. J69A, no. 4, pp. 539-42, April 1986. (A)

[599] P.V. Anand Mohan, V. Ramchandran and M.N.S. Swami, "Parasitic compensated single amplifier SC biquads," IEEE Trans Circuits \& Syst., vol. 33, no. 4, pp. 58-60, April 1986. (B)

[600] G.W. Roberts, D.G. Nairn and A.S. Sedra, "On the implementation of fully differential switched capacitor ladder filter" IEEE Trans. Circuits \& Syst. vol. 33, no. 4, pp. 452-5, April 1986. (B)

[601] J. Pennock, "Switched capacitor filter without the switches," New Electron., vol. 19, no. 7, pp. 43-4, April 1986. (D)

[602] G.A. Nenov, "Synthesis of switched-capacitor using nonideal immittance converters," 7th European conf. on Electrotech. Advance Technology and process in communi. and power systems, Paris, pp. 671-6, April 1986. (A)

[603] S. Ciochina, "Computer-aided analysis of switched capacitor filters," Rev. Roum. Sci. Tech. Ser. Electrotech. \& Energy, vol. 31, no. 2, pp. 163-8, April 1986. (D) 
[604] V.I. Georgiev and K.P. Stantchev, "Simple approach to analysis of switched capacitor circuit with nonideal op amp," Electron. Lett., vol. 22, no. 8, pp. 4245, April 1986. (B)

[605] C. Callion, J.P. Roche, C. Terrier and M. Schmotzer, "Mask-programmable switched capacitor filter," Elektroink. vol. 36, no. 8, pp. 54-62, April 1986. (A)

[606] K. Nakayama, Y. Satoh, M. Naka and Y. Nukada, "A single-chip SC line equalizer system for full duplex multi bit rate digital communication," ICASSP 86, Tokyo, pp. 1521-4, April 1986. (H)

[607] J. Mikula, "Inductor with various types of transformers," Elektrotech. Circuits \& Syst., vol. 37, no. 3, pp. 212-16, May 1985. (F)

[608] Y. Horio, M. Yamamoto and S. Mori, "Switched capacitor impedance simulation circuit with unity gain buffers," Trans. Inst. Electron. \& Communi. Engg., vol. E69, no. 5, pp. 610-19, May 1986. (F)

[609] G.W. Robert, W.M. Snelgrove and A.S. Sedra, "Switched capacitor state space filter using intermediate function synthesis," 86 Int. symp. on circuits and systems, San Jose, pp. 614-17, May 1986. (D)

[610] S. Fotopoulos, "Zero forming capacitor optimization in SC biquad," Int. J. Electron, vol. 60, no. 5, pp. 565-70, May 1986. (D)

[611] G.S. Moschytz and J.J. Mulawka, "New methods of direct closed form analysis of switched capacitor networks," 86 Int. symp. on circuits and systems, San Jose, vol. 1, pp. 369-72, May 1986. (A)

[612] Q. Lu, W.M. Snelgrove and A.S. Sedra, "Switched capacitor implementation of complex filters," 86 Int. symp. on circuits and systems, San Jose, vol. 3, pp. 1121-4, May 1986. (D)

[613] I. Ooto, F. Ueno and T. Inoue, "Realization analysis of a new switched capacitor DC-DC converter," 86 Int. symp. on circuits and systems, San Jose, vol. 3, pp. 1635-8, May 1986. (G)

[614] D.G. Nairn and A.S. Sedra, "Circuit and design technique for full-differential switched capacitor filters," 86 Int. symp. on circuits and systems, San Jose, vol. 2, pp. 603-6 May 1986. (D)

[615] N. Attaie and B.K. Ahuja, "Computer-aided design and analysis of a voice-band modem switched capacitor filter," 86 Int. symp. on circuits and systems, San Jose, vol. 1, pp. 141-4, May 1986. (D)

[616] C.H. Wei and W.K. Jocl, "Switched capacitor adaptive notch filter. 86 Int. symp. on circuits and systems, San Jose, vol. 2, pp. 607-8, May 1986. (D)

[617] Y. Horio and S. Mori, "LDI design of switched capacitor high pass ladder filter," 86 Int. symp. on circuits and systems, San Jose, vol. 2, pp. 612-13, May 1986. (D)

[618] J.J. Mulawka, "Some properties of passive switched capacitor networks," 86 Int. symp. on circuits and systems, San Jose, vol. 1, pp. 361-4, May 1986. (A)

[619] J.G. Ye and L.H. Zhao, "Computer simulation of SCN with improved nodal approach," 86 Int. symp. on circuits and systems, San Jose, pp. 145-58, vol. 1, May 1986. (A)

[620] A. Optal, J. Vlach and K. Singhal, "Analysis and sensitivity of periodically switched linear networks," 86 Int. symp. on circuits and systems, San Jose, vol. 1, pp. 380-1, May 1986. (A) 
[621] D. Asta, "Analysis and design of a hybrid Switched capacitor phase locked loops," 86 Int. symp. on circuits and systems, San Jose, vol. 1, no. 365-8, May 1986. (H)

[622] S. Chen, S. Li and X. Zho, "Analysis of SCN's using time invariant topologies," 86 Int. symp. on circuits and systems, San Jose, vol. 1, pp. 377-9, May 1986. (D)

[623] L.B. Wolovitz and J.I. Sewell, "Efficient computer techniques for the exact analysis of all nonideal effects of switched capacitor networks in the time domain," 86 Int. symp. on circuits and systems, San Jose, vol. 1, pp. 373-6, May 1986. (A)

[624] K. Mastu, T. Sakane, S. Abou, K. Chikaoka and M. Teramoto, "Switched capacitor filter using frequency dependence impedance," 86 Int. symp. on circuits \& systems, San Jose, pp. 601-2 May 1986. (D)

[625] A.E. Said, "High order filter realization using new proposed loop biquad blocks," 86 Int. symp. on circuits \& systems, San Jose, vol. 2, pp. 593-6, May 1986. (D)

[626] J.L.Huertas and A. Rodriguez, "Rational switched capacitor networks," 86 Int. symp. on circuits \& systems, San Jose, vol. 1, pp. 479-82, May 1986. (A)

[627] C. Wang, R. Castello and P.R. Gray, "A scalable high performance switched capacitor filter," 86 Int. symp. on circuits \& systems, San Jose, vol. 5, pp. 622-5 May 1986. (D)

[628] T.S. Rathore and B.B. Bhattacharyya, "Stray insensitive active-SC realization of high order filter with reduced number of components," 86 Int. symp. on circuits \& systems, San Jose, vol. 2, pp. 597-600, May 1986. (D)

[629] X. Cai, E. Sanchez-Sinencio and R.L. Geiger, "Poles zero pairing strategy for area and sensitivity reduction in cascade SC-filters," 86 Int. symp. on circuits \& systems, San Jose, vol. 2. pp. 609-11, May 1986. (D)

[630] L. Toth and E. Simonyi, "Explicit formula for analyzing general switched capacitor networks," 86 Int. symp. on circuits \& systems, San Jose, vol. 3, pp. 1177-8 May 1986. (A)

[631] T. Takabe and M. Nayashihara, "SC variable delay equalizer complex circuit structure," 86 Int. symp. on circuits \& systems, San Jose, New York, IEEE, pp. 1125-8, vol. 5, May 1986. (H)

[632] K. Nagraj, K. Singhal, T.R. Viswanathan and J. Vlach, "Switched capacitor circuits with reduced sensitivity to finite amplifier gain," 86 Int. symp. on circuits \& systems, San Jose, pp. 617, May 1986. (B)

[633] G. Espinosa, F. Verdad and F. Maloberti, "Low frequency noise reduction in high order switched capacitor filters," 86 Int. symp. on circuits \& systems, San Jose, pp. 734-7, vol. 3, May 1987. (D)

[634] C. Sanz and K. Martin, "Realization of active filters with switched capacitor filters," Mundo Electron., no. 162, pp. 99-107, May 1986. (D)

[635] K. Halonen, M. Steyaert and W. Sansen, "Micro power 4th order elliptical SC low pass filter," 86 Int. symp. on circuits \& systems, San Jose, pp. 724, May 1986. (D)

[636] B. Styblinska, "On frequency domain analysis and sensitivity calculation of switched capacitor circuits," Acta Polytech Ceske Vye Uceni Tech. V. Pr-III, no. 15 , pp.69-75, May 1986 . (A) 
[637] P. Moos, "Synthesis of active RC networks with switched capacitor," Acta Polytech. Ceske Vys. Uceni. Tech. Pr-III, no. 15, pp. 117-22, May 1986. (A)

[638] K. Lacatette, "Universal switched capacitor filter with lower part count," EDN, vol. 31, no. 7, pp. 39-47, May 1986 (D)

[637] D.G. Gilbert and J.I. Sewell, "Application of equivalent network theory to stray insensitive switched capacitor filters," 1986 Sagara Colloquium on 'Electronics filters London, IEE, pp. 3/7, May 1986. (A)

[639] J.J. Mulawka, "Switched capacitor realization of a multiple feedback networks," Acta Polytech Ceske Vye Uceniv Pr-III, no. 15, pp. 63-8, May 1986. (A)

[640] W.J. Helms, "A switched capacitor filter compiler," 86 Int. symp. on circuits and systems, San Jose, May 1986. (D)

[641] K. Halonen, M. Steyaert and W. Sansen, "A micro power 4th order elliptical SC low pass filter," 86 Int. symp. on circuits and systems, San Jose, pp. 324-7, May 1986. (D)

[642] P. Antoniazzi, "Low pass switched capacitor filter," New Electron., vol. 19, no. 2, pp. 27, June 1986. (D)

[643] T. Inoue, F. Ueno and S. Masuda, "Stray insensitive fully balanced band pass switched capacitor immittance converters," Trans. Inst. Electron. \& Communi. Engg. Jpn. Sect E., vol. E69 no. 1 pp. 1-3, June 1986. (F)

[644] T. Nishi and T. Kunihiro, "Synthesis of stray insensitive switched capacitor circuit which realize several transfer function simultaneously," Trans. Inst. Electron. \& Communi. Engg. vol. J69A, no. 1, pp. 71-9, June 1986. (A)

[645] T. Inoue, F. Ueno and S. Masuda, "Low sensitive bilinear switched capacitor low pass filter using fully balanced circuit," Trans. Inst. Electron. \& Communi. Engg., vol. E68, no. 6, pp. 722-5, June 1986. (D)

[646] A. Cichocki and R. Unbehauen, "A novel switched-capacitor four quadrant analog multiplier/divider and some of its applications," IEEE Trans. Instr. \& Meas., vol. 5, no. 2, pp. 156-62, June 1986. (H)

[647] A. Dela Plaza. "High frequency switched capacitor filter using unity gain buffer," IEEE J. Solid State Circuits, vol. 21, no. 3, pp. 470-7, June 1986. (D)

[648] J.T. Taylor and J. Mavor, "Exact design of stray-insensitive switchedcapacitor LDI ladder filter from unit element prototype," IEEE Trans. Circuits \& Syst. vol. 33, no. 6, pp. 613-22, June 1986. (D)

[649] A.E. Said and M.E. Zaghloal, "Stray-free switched capacitor general biquad blocks," IEE Proc. G, vol. 133, no. 3, pp. 154-8, June 1986. (D)

[650] G.S. Moschytz and J.J. Mulawka, "Direct analysis of stray insensitive switched capacitor networks using signal flow graph," IEE. Proc. G, vol. 133, no. 3, pp. 145-53, June 1986. (A)

[651] H.M. Sandler and A.S. Sedra. "Sine-wave generation using high order low pass switched capacitor filter," Electron. Lett., vol. 22, no. 12, pp. 635-6, June 1986. (D)

[652] T. Fulop, "Amplifier slew rate and frequency dependent gain effects in switched-capacitor circuits," Period. Polytech. Electr. Engg., vol. 30, no. 2-3, pp. 103-12. 1986. (A)

[653] T. Porneczi, "Fast analysis of active switched capacitor filters III," Period. Polytech. Electr. Engg. vol. 30, no. 2-3, pp. 113-20. 1986. (D) 
[654] J. Gau, "Monte Carlo analysis of SC filters," Period, Polytech. Electr. Engg., vol. 30, no. 2-3, pp. 121-31, 1986. June 1986. (D)

[655] Kyung Honyang, Kim Wond Chan and Lee Choon, "CMOS op-amp. for switched capacitor filter application," J. Korea Inst. Electron. Engg. vol. 23, no.4, pp. 59-65. June 1986. (D)

[656] T. Tron, "Sensitive analysis of switched capacitor networks," Period. Polytech. Electr. Engg., vol. 30, no. 2-3, pp. 113-20. 1986. (A)

[657] B. Nowrouzian and M.H. Hamza, "DC motor control using switched" capacitor circuit," Proc. of the Iasted Int. Symp. on the high technology in the power industry Bozman, Mtusaanaheim, USA, pp. 352-7, June 1986. (H)

[658] N. Sevastopoulos, "Switched capacitor filter without DC error," Electron. Ind., vol. 17, no. 4, pp. 90, July 1986. (D)

[659] U.V. Wali, R.N. Pal and B. Chatterjee, "Compact modified approach for switched capacitor networks analysis," IEEE CAD Integrated Circuits \& Systems, no. 5, p. 3-6, July 1986. (A)

[660] H. Matsumoto and K. Watenable, "Switched-capacitor algorithmic digitalto-analog converter," IEEE Trans. Circuit \& Syst. vol. 33, no. 7, pp. 721-4, July 1986. (G)

[661] E. Hayahara, T. Suzuki and S. Kadowaaki, "Synthesis of single amplifier switched capacitor filters," Electron. \& Communi., vol. 69, no. 8, pp. 59-65, August 1986. (D)

[662] T. Nishi and T. Kunihiro, "On the synthesis of stray-insensitive switched capacitor biquads," Technol. Rep. Kyushu, Univ., vol. 59, no. 4, pp. 529-35, August 1986. (D)

[663] A. Hyogo and K. Sekine, "A synthesis of SC inductor using UGB's," Trans IECE, vol. J69A, no. 8, pp. 1058-6, August 1986. (F)

[664] T. Tron, "Sensitivity and group delay analysis of switched capacitor networks," Proc. of the 8th Colloquium on Microwave Communi. Budapest, pp. 22930, August 1986. (A)

[665] E. Halasz, L. Gefferth and E. Hadi, "Optimization of cascaded switched capacitor biquads," Proc. of the 8th Colloquium on Microwave Communi. Budapest, pp. 231-2, August 1986. (D)

[666] T.G. Kouyoumdjev and N.G. Nenov, "Synthesis of high order stray insensitive offset compensated SC filters with full clock period held output voltage," Proc. of the 8th Colloquim on Microwave Communi. Budapest, pp 129-30, August 1986. (D)

[667] L. Toth and E. Simonyi, "General noise analysis of ideal and lousy switched capacitor networks," Proc. of the 8th Colloquium on Microwave Communi. Budapest., pp. 211-12, August 1986. (D)

[668] P. Moos, M. Laiert and J. Kadlee, "Compensated switched capacitor Npath filters," Proc. of the Colloquium Microwave Communi. Budapest, pp. 2078, August 1986. (D)

[669] A. Cichocki and R. Unbehauen, "Simple technique for analysis of SC networks using general purpose circuit simulation program," Electron. Lett., vol. 22 , no. 18, pp. 956-8, August 1986. (A)

[670] J. Vlach, K. Singhal, E. Chriten, M. Vlach and R. Chadha, "Computer 
aided design of linear and switched capacitor networks," Proc. of 8th Colloquium on Microwave Communi., Budapest, pp. 207-8, August 1986. (A)

[671] Y. Yoshida, Y. Murahara and H. Kumbara, "An automatics filter using switched capacitor performance as an automatics equalizer at low $\mathrm{S} / \mathrm{N}$," Electron. \& Communi., vol. 68, no. 4, pp. 84-92, Sept. 1986. (D)

[672] S. Eriksson and K. Chen, "Bilinear transformed switched capacitor leapfrog realized with bilinear integrator," Proceeding of European signal processing conf. The Hague, Netherlands vol. 1, pp. 41-4, Sept. 1986. (D)

[673] P.M. Van Peteghem, "Distortion measurements in SC filter using LMS fitting routines," Proceeding of European signal processing conf. The Hague, Netherlands pp. 997-1000, vol. 2, Sept. 1986. (D)

[674] H.M. Sandler and A.S. Sedra, "A programmable switched capacitor low pass ladder filter," 86 Canadian conf. on VLSI, Montreal, Canada, pp. 253-8, Oct. 1986. (D)

[675] J. Lopez and G. Gonzalez, "Development of filter with switched capacitor technology of an op-amp, using spice," Rev. Telegr. Electron. vol. 75, no. 877, pp. 1407-11, Sept. 1986. (D)

[676] V. Gerrgiev and K. Stantchev, "Adequate SC model of op amp with finite DC gain \& SC biquads analysis," Electron. Lett., vol. 22, no. 19, pp. 996-7, Sept. 1986. (B)

[677] M. Tsckahar, S. Fukai and H. Ishikawa, "Compensation technique for clock feed through effect on switched resistor circuits," Trans. Inst. Electron. \& Communi. Eng. Japan Part. A, vol. 69A, no. 9, pp. 1176, Sept. 1986. (A)

[678] J.O. Scanlan and P.J.O. Donova "Adaptive realization of wave switchedcapacitor filters with reduced capacitance spread," Electron. Lett., vol. 22, no. 19, pp. 969-70, Sept. 1986. (D)

[679] H. Seki and S. Mori, "A/D and D/A converters using switched capacitor amplifier," Electron. \& Communi. Jpn. Part. I, vol. 69, no. 101, pp. 37-45, Sept. 1986. (G)

[680] V. Georgiev and Y.P. Tsividis, "Adequate SC model of op-amp with finite DC gain bandwidth suitable for two op. amp. SC biquads," Electron. Lett., vol. 22, no. 19 , pp. 1026, Sept. 1986. (D)

[681] A. Dabrowski, "Design multirate VIS-SC filters," Twelfth European solid state circuits conf., Delft, Netherlands, pp. 131-3, Sept. 1986. (D)

[682] H. Walscharts, L. Kustermans, L. and W. Sanser, "Noise optimization of switched capacitor biquads," Twelfth European solid state circuits conf., Delft, Netherlands, pp. 137-9, Sept. 1986. (D)

[683] J. Buddefeld, P. Richard, W. Brockhrde, B.J. Hostick and G. Zimmer, "CAD tools for the design and analysis of switched capacitor networks," Twelfth European solid state circuits conf., Delft, Netherlands, pp. 140-2, Sept. 1986. (A)

[684] P. Van-Peteghem and W. Sansen, "Single versus complementary switches, a discussion of clock feed through in SC circuits," Twelfth European solid state circuits conf., Delft, Netherlands, pp. 143-5, Sept. 1986. (A)

[685] M. Tawfik, G. Mazare and P. Senn, "A 1-Mhz cutoff frequency CMOS elliptical low pass switched capacitor ladder filter," Twelfth European solid state circuits conf., Delft, Netherlands, pp. 137-9, Sept. 1986. (D) 
[686] P.J.O. Donovan, "Parasitic-insensitive realization of switched capacitor leapfrog ladder filters with reduced number of op. amps," Electron. Lett., vol. 22, no. 21, pp. 1085-6, Sept. 1986. (D)

[687] A. Cichocki and R. Unbehauen, "MOS SC micro system for generating trigonometrical functions and their inverse," Electron. Lett. vol. 22, no. 20, pp. 1056-7, Sept. 1986. (H)

[688] M. Ishikawa, "A synthesis of switched capacitor balanced modulator," Trans. Inst. Electron. \& Communi. Eng. Jpn. Part-C, vol. J69C, no. 10, pp. 13835, Sept. 1986. (H)

[689] P. Selwa, "The dxer's SCF switched capacitor filter," 73 Amat. Radio, no. 33, pp. 34-6, Sept. 1986. (D)

[690] J.F. Duque-Carrillo, J.J. Pena-Bernal and J.M. Vega-Fernandez. "Anwicap-a, computer-aided method for symbolic transfer function determining switched capacitor networks," Int. J. Electron., vol. 61, no. 4, pp. 517-29, Oct. 1986. (A)

[691] G.V. Eaton, D.G. Nairn, W.M. Snelgrove and A.S. Sedra, "SICOMP: a silicon compiler for switched capacitor filters," 86 Canadian conf. on VLSI, Montreal, Canada, pp. 349-54, Oct. 1986. (D)

[692] V.I. Georgiev and K.P. Stantchev, "State space switched-capacitor filter design based on single op. amp. biquads," IEE Proc. G, vol. 133, no. 5, pp. 2515, Oct. 1986. (D)

[693] K. Nagraj, J. Vlach, T.R. Viswanathan and K. Singhal, "SC integrator with reduced sensitivity to amplifier gain," Electron. Lett., vol. 22, no. 21, pp. 1103-5, Oct. 1986. (B)

[694] M. Saghafi and M. Hasler, "Switched capacitor filters with a row dominant nodal a admittance matrix," Int. J. Circuit Theory \& appl., vol. 19, no. 4, pp. 295-304, Oct. 1986. (D)

[695] M. Arnoldt, "Switched capacitor techniques: versatile LF-filter," Furkschan., no. 22, pp. 64-4, Oct. 1986. (H)

[696] E. Keyes, C. Gregoine, J. Watt and T. Kwashiiewski, "Third order switched-capacitor CMOS noise shamping-sigma delta coder for over sampled A/ D conversion," Canadian Conf. on VLSI, Montreal, Canada pp. 259-64, Oct. 1986, (G)

[697] F. Ueno, T. Inoue, K. Sugitani and M. Inoue, "Cyclic switched capacitor A/D converter," Trans IECE, vol. E69, no. 10, pp. 1093-103, Oct. 1986. (G)

[698] F. Ueno, T. Inoue, K. Sugitani and M. Inoue, "Cyclic switched capacitor A/D converters," Trans IECE, vol. E69, no. 10, pp. 1093-103, Oct. 1986. (F)

[699] K. Nohara, "Switched capacitor negative conductance," Trans. Inst. Inf. Communi Engg. C, vol. J71C, no. 11, pp. 1597-9, Nov. 1986. (H)

[700] G.W. Robert, D.B. Ribber and M. A. Copeland, "Comments on "On implementation of fully differential switched capacitor ladder filters," IEEE Trans Circuits \& Syst. vol. 33, no. 11, pp. 1152, Nov. 1986. (D)

[701] H. Bacher, "Transfer function for switched capacitor and wave digital filters," IEEE Trans Circuits \& Syst. vol. 33, no. 11, pp. 1138-42, Nov. 1986. (E)

[702] T. Cajka and T. Dostal, "Symbolic analysis of switched capacitor networks," Slaboproudy. Obz, vol. 47 no. 11, pp. 574-6, Nov. 1986. (A)

[703] T. Inoue, F. Ueno, S. Masuda and T. Matsumoto, "Low sensitive switched 
capacitor band pass filters using two path and voltage inversion technique," Trans. Inst. Electron. \& Communi. Eng. Jpn. Sect. E, vol. 69, no. 11, pp. 1144-52, Nov. 1986. (D)

[704] Shen Shi-Hu, Hi Su-Qin and Zhao Xaio-Qun "Using time invariant topology analysis of switched capacitor filter in time domain," Acta Electronic. Sin, vol. 14 , no. 6 , pp. $27-35$, Nov. 1986 . (D)

[705] P. Lutz and H. Weinrichter, "Calculation of image frequency response of filters with time variant topology by means of equivalent RC-circuits," Frequentz, vol. 40 , no. 11 , pp. 326-32, Nove. 1986 (D)

[706] J. Vlach, "Hand analysis of switched capacitor networks," IEEE Circuits \& Devices Mag. vol. 2, no. 6, pp. 11-16, Nov. 1986. (A)

[707] R. Ubehauen and A. Circhocki, "Contribution to the synthesis of SC networks for linear and nonlinear signal processing," NTZ-Arch, vol. 8, no. 11, pp. 271-85, Nov. 1986. (A)

[708] A. Kalin, R. Sigg and G.S. Moschytz, "Designing cellular parasitic insensitive SC ladder filters suitable for mask programmable manufacture," Electron. Lett. vol. 22, no. 23, pp. 1250-2. Nov. 1986. (D)

[709] P. Nagel, "Computer controlled orthogonal filter in switched capacitor technology," Elektronik, vol. 35, no. 24, pp. 85-8. Nov. 1986. (D)

[710] H.M. Sanlera and A.S. Sedra, "Programmable switched capacitor low pass ladder filters," IEEE J. Solid State Circuits, vol. 21, no. 6, pp. 1109, Nov. 1986. (D)

[711] A.M. Davis and R.R. Smith, "Design of state variable SC filters," IEEE Trans Circuits \& Syst., vol. 33, no. 12, pp. 1248, Dec. 1986. (D)

[712] R.M. Payton and M. Savic, "SCORPION DAC, a new family of switched capacitor D/A converters," Electron. Lett., vol. 22, no. 25, pp. 1320, Dec. 1986. (G)

[713] A.M. Davis and R.R. Smith, "Design of state variable SC filters by means of polynomial transformation," IEEE Trans Circuits \& Syst., vol. 33, no. 12, pp. 1248, Dec. 1986. (D)

[714] B.S. Song and P.R. Gray, "Switched capacitor high Q band pass filters for IF applications," IEEE, J. Solid State Circuits, vol. 21, no. 6, pp. 924-23, Dec. 1986. (D)

\section{7}

[715] T. Dostal and J. Pospisil, "Switched multi-input blocks and their use in the synthesis of switched capacitor networks," Slaboproudy Obz, vol. 48, no. 1, pp. 1-6, Jan. 1987. (A)

[716] J. Cajka and T. Dostal, "Determination of the sensitivity of voltage to change of switched-capacitor circuits parameters," Slabop. Obz, vol. 48, no. 1, pp. 43-5, Jan. 1987. (A)

[717] U. Bernhardt, "Equivalent circuits for sampling noise in SC integrators," Nachrichten. Electronik, vol. 37, no. 5, pp. 187-9. 1987. (B)

[718] J. Assael, P. Senn and M. Tawfik, "A switched capacitor filter silicon complier," Tokyo Japan Bus Centre Acad Soc. pp. 9-10 Symp. on VLSI Circuits. Digest of Technical Paper. 1987. (D) 
[719] A. Shimazu, K. Nurakami and H. Fuji, "Integrated circuit development in switched capacitor filters," Iwatsu Tech Tep., vol. 24, no. 4, pp. 91-7, 1987. (D)

[720] H. Matsumoto, H. Shimizu and K. Watanable, "A switched capacitor charge balancing analog-to-digital converter," Conf. Proc. IEEE Comput. Soc. Press, pp. 165-8, 1987. (G)

[721] J. Mikula, "Unity gain amplifier in the switched capacitor," Electrotech. Circuits \& Syst., vol. 38, no. 8, pp. 609-17, 1987. (B)

[722] D. Biolck, "Optimization of the capacitive ratios in SC network," Elektrotech. Circuits \& Syst., vol. 38, no. 8, pp. 618-27, 1987. (A)

[723] L. Ping and J.I. Sewell, "The LUD approach to switched capacitor filter design," 87 Saraga Colloquium on Electronic filters, London, England IEE pp. $7 /$ 1-7, 1987. (D)

[724] F. Anday, "Synthesis of switched-capacitor active filters: Z-domain equivalent admittance approach," Int. J. Circuit Theory \& Appl., vol. 15, no. 1, pp. 85-7, Jan. 1987. (D)

[725] M. Kaneko, "A systematic design for switched capacitor networks based on discrete time state equation," Trans. Inst. Electron. Inf. Communi. Eng. A, vol. J70A, no. 1, pp. 73-81, Jan. 1987. (A)

[726] C. Toumazou, "High gain op-amp. for GaAs switched capacitor filter applications," 87 Saraga Collouium on Electronic filters, London, England IEE, pp. 6/1-7, 1987. (D)

[727] C.L. Winder and R.E. Massara, "A CAD tools for analogue circuit design, with a particular reference to switched capacitor filter synthesis," 87 Sarga Colloquium on "Electronic filters London, IEE, pp. 5/1-6, 1987.

[728] M.M.A.S. Nassar, "Switched capacitor filter using digital recursive filter technique," Modelling Simulation \& Control. A, vol. 11, no. 3, pp. 15-28, 1987. (E)

[729] M.A. Tan, C. Acar and M.S. Ghuasi, "Design of switched-capacitor filters using nonideal op-amp," J. of the Frankline Inst., vol. 323, no. 1, pp. 55-72, Jan. 1987. (D)

[730] T.S. Rathore, S.M. Faruque and B.B. Bhattacharyya, "A stray-insensitive single switched capacitor ladder realization of an arbitrary order low pass filter," Proc. IEEE, vol. 75, no. 1, pp. 168-9, Jan. 1987. (D)

[731] D. O'Neil, "Switched-capacitor voltage converter in bipolar technology with $100 \mathrm{~mA}$ output current," Solid State Circuits Conf. Digest of first edition, New York, pp. 218-27, Feb. 1987. (H)

[732] A. Cichocki and R. Unbehauen, "Simplified analysis of arbitrary switchedcapacitor networks," IEE Proc. G, vol. 134, no. 1, pp. 45-53, Feb. 1987. (A)

[733] M.J. Nigam and M.M. Krishna, "Switched-capacitor first order all pass circuits using two terminals negative input impedance building blocks," Int. J. Electron., vol. 62, no. 2, p. 313-15. Feb. 1987. (D)

[734] M. Trezz, "Active biquadratic switched-capacitor functional block," Slaboproudy Obz, vol. 48, no. 2, pp. 58-62, 1987. (D)

[735] G.W. Robert, W.M. Snelgrove and A.S. Sedra, "Switched capacitor realization of nth-order transfer function using single multiplexed op amp.," IEEE Trans. Circuits \& Syst., vol. 34, no. 5, pp. 140-8, Feb. 1987. (D) 
[736] H. Unger and U. Bernhardt, "On the influence of non white voltage noise of an op-amp. on the noise behavior of SC integrator," Nachrichten. Elektronik, vol. 37, no. 2, pp. 63-6, Feb. 1987. (B)

[737] M. Kaneka and M. Onoda, "A single-flow graph representation for switched capacitor networks and its application to a SC circuit design," Electron. \& Communi. Jpn Part. I., vol. 70, no. 2, pp. 35-45, Feb. 1987. (A)

[738] K. Martin, L. Ozcolak, Y. Lee and G.C. Temes, "A differential switchedcapacitor amplifier," IEEE J. Solid State Circuits, vol. 22, no. 1, pp. 104-6, Feb. 1987. (B)

[739] K. Martin, G.C. Temes and L.N. Larson, "GaAs switched capacitor circuits for video signal processing," IEEE Int. symp. on solid state circuits, New York, pp. 40-1, Feb. 1987. (H)

[740] J.T. Taylor and D.G. Haigh, "Stray-free first order circuit for correction of sampled and hold amplitude distortion in switched-capacitor filters," Electron. Lett., vol. 23, no. 5, pp. 177-8, Feb. 1987. (D)

[741] K. Hajek and J. Sedlcek, "On power in branches with switched-capacitor," Slaboproudy Obz, vol. 48, no. 3, pp. 147-8, March 1987. (H)

[742] P. Moos, Z. Muller and Z. Stahno, "A design approach to the switchedcapacitor filter with attenuator poles by means of oriented graphs," Slaboproudy Obz, vol. 48, no. 3, pp. 123-9, March 1987. (D)

[743] K. Lacanethe, "A universal switched-capacitor band pass filter of the 4th order," Electron. Ind, vol. 18, no. 3, pp. 102, 1987. (D)

[744] H. Matsumoto and K. Watanable, "A switched-capacitor digital capacitance meter," Rep. Grad. Sch. Electron. Sci. Technol. Shizuoka, no. 8, pp. 7380, March 1987. (H)

[745] I. Dendo, "Noise and drift on switched-capacitor analog circuits for CMOS IC sensor interface," Mem. Tohokur. Inst. Technol. Ser., no. 7, pp. 225-39, March 1987. (H)

[746] B.L. Rojo and W.W. Poliscuk, "Analysis of SC real networks," Proc. of Meleocon 87 Medteranean Conf. (New York, USA IEEE), March 1987. (A)

[747] C. Szenttirmai, "Software for switched capacitor design," Automated Design and Engineering for Electronics-Technical session, Anaheim, pp. 155-65, April 1987. (A)

[748] Z. Hong, "A analogue four-quadrant CMOS multiplier-divider with switched capacitor," Tokyo, Japan Bus Center Acad Soc. Japan, April 1987. (H)

[749] K. Kondoh and K. Watanable, "A audio-ranging switched capacitor analog to digital converters," Conf. Proc. IEEE Instr. \& Meas., Technology, (New York, USA IEEE), pp. 115-18, April 1987. (G)

[750] A. Barua, "Novel parasitic insensitive SC large pole selective $Q$ band pass filters with less capacitor spread with low pole "Q" sensitivity," Int. J. Electron., vol. 62, no. 4, pp. 637-4, April 1987. (D)

[751] H. Matsumoto and K. Watanable, "Spika-free switched-capacitor circuits," Electron. Lett., vol. 23, no. 8, pp. 428-9, April 1987. (H)

[752] T. Rathore and B.B. Bhattacharyya, "Systematic approach to the time multiplexing of stray-insensitive SC networks," IEE Proc. G, vol. 134, no. 2, pp. 83-94, April 1987. (A) 
[753] K. Nagraj and R.E. Turner, "Precision switched-capacitor attenuator," IEEE Trans Circuits \& Syst., vol. 34, no. 4, pp. 446-7, April 1987. (H)

[754] W.M. Sansen, H. Quiting and K.A. Halonen, "Transient analysis of charge transfer function in SC filter gain-error and distortion," IEEE J. Solid State Circuits, vol. 22, no. 2, pp. 268-71, April 1987. (D)

[755] K.A. Halonen, W.M. Sansen and M. Steyeart," A micro power fourthorder elliptical switched-capacitor low pass filter," IEEE J. Solid State Circuits, vol. 22, no. 2, pp. 164-73, April 1987. (D)

[756] Y. Horio and S. Mori, "Frequency dependence voltage controlled current source pair by using the improved is-isc," Trans Inst. Electron. Inf. Communi. Engg. E., vol. E70J, no. 4, pp. 422-9, April 1987. (H)

[757] M. Sanz and A. Puert, "Compact formulation for exact analysis of nonideal SC circuits," Electron. Lett., vol. 23, no. 11, pp. 554-5, April 1987. (A)

[758] H. Jamal, "Operational amplifier free active SC simulator of LC ladder based on BBD principle," IEE Proc. G, vol. 134, no. 2, pp. 111-15, April 1987.

[759] J. Cajka and T. Dostal, "Circuit function of switched capacitor two port," Slaboproudy Obz, vol. 48, no. 4, pp. 201-5, April 1987. (A)

[760] D.C. Von Gruenigen, "Introduction to the SC technique," Elektroiker, no. 5, pp. 73-8, May 1987. (H)

[761] K. Nakayama and Y. Takahashi, "A singal chip SC the equalizer system for all duplex multi bit rate digital transmission," 87 IEEE Int. symp. on circuits and systems, Philadelphia, pp. 1521-4, May 1987. (H)

[762] S.M. Faruque, L. Ngoc and W. Martens, "Switched capacitor building blocks comparable with semicustom VLSI," 87 IEEE Int. symp. on circuits and systems, Philadelphia, pp. 339-4, vol. 2, May 1987. (A)

[763] L.E. Larson, "Filter design strategies for GaAs switched capacitor circuits," 87 IEEE Int. symp. on circuits and systems, Philadelphia, pp. 217-20, vol. 1, May 1987. (D)

[764] K. Nagraj, T.R. Viswanathan, J. Vlach and K. Singhal, "Switched capacitor circuits with reduced sensitivity to amplifier gain," IEEE Trans Circuits \& Syst., vol. 34, no. 5, pp. 524-32, May 1987. (A)

[765] T. Jarske and P. Heinonen, "Switched-capacitor linear medium hybrid filters," 87 IEEE Int. symp. on circuits and systems, Philadelphia, pp. 260-3, no. 2, May 1987. (D)

[766] E.I. EI-Masry, "Low sensitivity realization of switched capacitor filters," IEEE Trans Circuits \& Syst., vol. 34, no. 4, pp. 510-23, May 1987. (D)

[767] T. Inoue and F. Ueno, "Design of very low sensitivity low pass switchedcapacitor ladder filters," IEEE Trans Circuits \& Syst., vol. 34, no. 5, pp. 524-32, May 1987. (D)

[768] P.M. Van. Peteghem, "The enhancement of PSRR in single ended switched capacitor circuits," 1987 IEEE Int. Symp. on Circuits \& Systems, Philadelphia, pp. 68-71, vol. 1, May 1987. (H)

[769] K. Halonen and W.M. Sansen, "Effect of current spike in power supply on PSRR performance of switched-capacitor filters," 1987 IEEE Int. Symp. Circuits \& Systems, Philadelphia, pp. 69-7, May 1987. (D)

[770] A. Rodriguez-vazquez, A. Rueda, B. Perez-verdu and J.L. Huertas, "Novel electronic chaos generator using nonlinear switched capacitor circuits," 
1987 IEEE Int. Symp. on Circuits \& Syst., Philadelphia, pp. 684-7, May 1987. (H)

[771] G.W. Robert, W.M. Snelgrove and A.S. Sedra, "SC circuits simulation of state formulation derived from LC ladder network prototypes," 87 IEEE Int. symp. on circuits and systems, Philadelphia, pp. 722-5, vol. 3, May 1987. (D)

[772] Y. Cheng and P.M. Lin, "Symbolic analysis of general switched-capacitor networks new methods and implementation," 87 IEEE Int. symp. on circuits and systems, Philadelphia, pp. 55-9, vol. 1, May 1987. (A)

[773] J.E. Da. Franca and D.G. Haigh, "Optimum implementation of IIR switched capacitor decimators," 87 IEEE Int. symp. on circuits and systems, Philadelphia, pp. 76-9, vol. 1, May 1987. (H)

[774] W. Zheng-Gue, "Loop analysis of switched-capacitor networks with arbitrary k-phase and general inputs," Int. Symp. on Circuits \& Systems, Philadelphia, pp. 72-5, vol. 1, May 1987. (A)

[775] A. Kelin, R. Sigg and G.S. Moschytz, "A programmable design technique for cellular equivalent switched capacitor ladder filters," 87 IEEE Int. symp. on circuits and systems, Philadelphia, pp. 715-18, vol. 3, May 1987. (D)

[776] H. Baher, "Highly selective switched-capacitor filter with constant delay response," 87 IEEE Int. symp. on circuits and systems," Philadelphia, pp. 71921, vol. 3, May 1987. (D)

[777] D.M. Gee and S.R. Lurenson, "A low noise switched capacitor analogue front and 22 bismaden," Proc. of the IEEE Custom Integrated Circuits. (New York, IEEE) pp. 465-8, May 1987. (H)

[778] D.G. Haigh, "A review of some work on GaAs switched capacitor filters," 87 IEEE Int. symp. on circuits and systems, Philadelphia, vol. 3, pp. 1114-17, May 1987. (D)

[779] Y. Gao, W. Wang and R. Gu, "Novel linear transformation switched capacitor filter design," IEEE Int. symp. on circuits and systems, Philadelphia, pp. 734-4, vol. 3, May 1987. (D)

[780] A.M. Davis, "Exact SC synthesis of bilinearly transformed all pole analog filters using cascaded GCT sections," IEEE Int. symp. on circuits and systems, Philadelphia, pp. 746-3, vol. 3, May 1987. (D)

[781] D.G. Haigh, B. Singh and J.T. Taylor, "Low sensitivity switched-capacitor filters with maximum signal handing capability," IEEE Int. symp. on circuits and systems, Philadelphia, pp. 1110-13, vol. 3, May 1987. (D)

[782] D.J. Gilbert, G.L. Holden and J.I. Sewell, "Optimization of switchedcapacitor networks using equivalence transformation," 1987 IEEE Int. symp. on circuits and systems, Philadelphia, pp. 730-3, vol. 3, May 1987. (A)

[783] G. Fischer, "Switched-capacitor FIR filter designs," 1987 IEEE Int. symp. on circuits and systems, Philadelphia, pp. 742-5, May 1987. (E)

[784] I. Sasaki, "Switched capacitor realization of fourier analyzer using integrated feedback capacitance circuits," Trans. Electron. \& Communi. Engg, Jpn. Part 2, vol. 69, no. 5, pp. 90-9, May 1987. (A)

[785] M. Kudo and R. Hayashife, "A proposal of various recursive switched capacitor filters using a single op-amp. and experimental results," Trans Electron. \& Communi. Eng Jpn. Part 2, vol. 69, no. 2, pp. 84-92, May 1987. (D) 
[786] S. Osowak, "Computer simulation of SC circuits using NAP," Electron. Lett. vol. 23, no. 11, pp. 5, May 1987. (A)

[787] P.M. Van Peteghem, J.E. Dugue-Carrillo and E. Sanchez-Sinencio, "General Z-domain description of SC filters built with transconduction amplifiers," Linear Circuits \& Syst. and Signal Processing: theory and Appl., Phoenix, pp. 1519, June 1987. (D)

[788] S.M. Faruque, Tho Le-Ngoc, "Weighted frequency SC-DAC comparable with semi-custom VLSI," Binomial Symp. on Communi. Kingston, Canada, pp. 17-20, June 1987. (H)

[789] W. Rahe, "Switched capacitor audio filter variable bandwidth, tunable centre frequency step side flanks," VHE Communi., vol. 19, no. 2, pp. 113-25, June 1987. (D)

[790] V. Kahoum, "Extension of a program for symbolic analysis of switched capacitor networks," Slaboproudy. Obz., vol. 48, no. 6, pp. 296-9, June 1987. (A)

[791] D.C. Von Gruenigen, "Introduction to the SC technique II," Electroniker., pp. 88-94, no. 6, June 1987. (H)

[792] G.C. Temes, "The compensation of amplifier offset and finite-gain effects in the switched capacitor circuits," Period Polytech Electro Engg., vol. 30, no. 4, pp. 147-57, June 1987. (B)

[793] V.I. Georgiev and K.P. Stantchev, "Method for analysis switched capacitor networks containing op. amp. with finite DC gain and bandwidth," IEEE Proc. G, vol. 134, no. 3, pp. 141-7, June 1987. (B)

[794] H. Walscharts, L. Kustermanns and W.M. Sansen, "Noise optimization of switched capacitor biquads," IEEE J. Solid State Circuits, vol. 22, no. 3, pp. 495-7, June 1987. (D)

[795] M. Tawjik and P. Senn, "A 3.6MHz cutoff frequency CMOS elliptical low pass switched capacitor," IEEE, J. Solid State Circuits, vol. 22, no. 3, pp. 37884, June 1987. (D)

[796] A. Handkiewicz', "Switched-capacitor circuits synthesis based on gyrator capacitor prototype," Int. J. Circuit Theory \& Appl., vol. 29, no. 7, pp. 92-4, June 1987. (H)

[797] U.V. Wali and R.N. Pal, "Switched capacitor networks for voice communication," J. Inst. Electron \& Telecommuni. Engg., vol. 32, no. 3, pp. 145-7, June 1987. (H)

[798] G. Simon, "An extended an resonator concept and its application in switched-capacitor DFT processors," Period Polytech. Electr. Engg., vol. 30, no. 2-3, pp. 81-5, June 1987. (H)

[799] N. Goto, M. Nishi and T. Suzuki, “A current conveyor II realization by MOSFET and its application to switched-capacitor filters," Electron. \& Communi. Jpn. Part 2, vol. 69, no. 1, pp. 10-17, June 1987. (D)

[800] G. Simon, “A stray-insensitive switched-capacitor delay," Period Polytech. Electr. Engg., vol. 30, no. 2-3, pp. 81-5, June 1987. (H)

[801] A.A. Abidi, "Linearization of VCO using switched capacitor feedback," IEEE J. Solid State Circuits, vol. 22, no. 3, pp. 494-6, June 1987. (C)

[802] T. Nishi and T. Kunikiro, "Synthesis of stray-insensitive switched-capacitor 
circuits which realize several transfer functions," Electron. \& Communi. Jpn. Part I, vol. 70, no. 6, pp. 21-31, June 1987. (A)

[803] A. Rodriguez-vaquez, A. Rueda, B. Perez-verdu and J.L. Huertas, "Chaos via a piece wise-linear switched capacitor circuit," Electron. Lett., vol. 23, no. 12, pp. 662-3, June 1987. (H)

[804] D.O. Neill, "Switched capacitor converter tackle advanced applications," Electron. Des., vol. 35, no. 14, pp. 147-52, June 1987. (H)

[805] M. Ishikawa, Y. Komatsu and T. Yanagisawa, "A synthesis of balanced type SC integrator based bilinear S-Z transformations," Trans. Inst. Electron. Inf. \& Communi. Engg. A, vol. J70A, no. 7, 1036-41, June 1987. (B)

[806] D. Shear, "Comparison reveal the pros and cons of designing of switched capacitor ICs," EDN, vol. 32, no. 13, pp. 83, June 1987. (H)

[807] P.M. Van Peteghem, W. Sansen, "Reduction in flicker noise with switched capacitor technology," Budapest, Hungary Omikk techoniform. pp. 177-82, July 1987. (H)

[808] G.S. Moschytz, "Elements of four port matrix theory as required for SC networks analysis," Int. J. Circuit theory \& Appl., vol. 151, no. 3, pp. 235-49, July 1987. (A)

[809] M. Ishikawa, "Synthesis of switched capacitor filters using voltage and charge variable," Electron. \& Communi. Jpn. Part I, vol. 70, no. 7, pp. 29-30, July 1987. (D)

[810] P.P. Landan, D. Melnik, "A reduced capacitor spread algorithm for elliptical band pass SC filters," IEEE J. Solid State Circuits, vol. 22, no. 4, pp. 6246, August 1987. (D)

[811] Coix Xuexang, E. Sanchez-Sinencio and R.L. Geiger, "Pole-zero pairing strategies for cascaded switched capacitor filters," IEE Proc. G, vol. 134, no. 4, pp. 199-204, August 1987. (D)

[812] M. Ishikawa, "Low sensitivity switched-capacitor integrator," Electron. Communi. Jpn. 1, vol. 70, no. 8, pp. 32-40, August 1987. (A)

[813] M.F. Fahmy, M:Y. Makky and M.M. Doss, "A method for frequencydomain analysis of switched capacitor filters," IEEE Trans Circuits \& syst., vol. 34, no. 8, pp. 955-60, August 1987. (A)

[814] T. Dostal and J. Mikula, "Novel design of switched-capacitor equivalents," Proc. of 8th Colloquium on Microwave Communication. (Amsterdam Netherlands, Elsevier), August 1987. (A)

[815] J. Mikula and K. Hajek, "Nonsymmetric inductors and their frequency filters applications," Electrotech Circuits \& Syst., vol. 38, no. 6, pp. 413-19, 1987. (D)

[816] Y.P. Tsividis and D. Anastassiou, "Switched capacitor neural networks," Electron. Lett., vol. 23, no. 18, pp. 958-9, August 1987. (A)

[817] S. Fotopoulos and T. Deliyannis, "Fully differential cascade of biquadratic SC filter," Proceeding of the European conf. on circuit theory and Design, Paris, pp. 89-8, Sept. 1987. (D)

[818] M. Nalecz, "Generalized analysis method of SC networks comparing op amp with finite DC gainwidth product value," Proceeding of the European conf. on circuit theory and Design, Paris, pp. 77-82, Sept. 1987. (A) 
[819] M. Nalecz, "Generalized analysis method of SC networks comparing op amp with finite DC gainwidth product value," Proceeding of the European Conf. on circuit theory and Design, Paris, pp. 77-82, Sept. 1987. (A)

[820] C. Acar and M.S. Ghausi, "Fully integrated active filter designing MOS technology and non balance structure," Proceeding of the European Conf. on circuit theory and Design, Paris, pp. 307-14, Sept. 1987. (D)

[821] J.L. Huertas, A. Rodriguez-Vazquez, A. Rueda and B. Perez-verdu, "On implementation of discrete map using switched capacitor network," Proceeding of the European Conf. on circuit theory and Design, Paris, pp. 408-19, Sept. 1987. (A)

[822] A.E. Said, K. Albidweiy, F.Z. Amer and E.M. Saad, "Fault diagnosis of switched capacitor circuits," Proceeding of the European conf. on circuit theory \& Design, Paris, pp. 771-6, Sept. 1987. (A)

[823] M.F. Fahmy, M.Y. Makky and M.T. Sobby, "Time and frequency domain analysis of nonideal switched capacitor circuits," Proceeding of the European conf. on Circuit Theory \& Design, Paris, pp. 83-4, Sept. 1987. (A)

[824] A. Handkiewicz, "Two dimensional SC filter design," Proceeding of the European Conf. on circuit theory and Design, Paris, pp. 621-6, Sept. 1987. (A)

[825] L. Kunsagi, L.E. Larson, K.M. Martine and G.C. Temes, "Switched capacitor circuits with reduced sensitivity to finite amplifier gain bandwidth and offset voltage," Proceeding of the European Conf. on circuit theory and Design, Paris, pp. 543-8, Sept. 1987. (B)

[826] S. Lachowicz and S. Krawczyk, "Influence of switch on resistance and capacitance on harmonic distortion in SC filter," Proceeding of the European Conf. on circuit theory and Design, Paris, pp. 777-82, Sept. 1987. (D)

[827] M. Nikodem and J.J. Mulawka, "On switched capacitor vector and transfer function synthesis," Proceeding of the European Conf. on circuit theory and Design, Paris, pp. 555-60, Sept. 1987. (A)

[828] H. Qiuting and W. Sansen, "Design technique for improved capacitor area efficiency in SC biquad," Proceeding of the European Conf. on circuit theory and Design, Paris, pp. 783-8, Sept. 1987. (D)

[829] T. Fulop and F. Montecchi, "Switched capacitor filter with offset insensitivity time continuous feedback integrator loop," Proceeding of the European Conf. on circuit theory and Design, Paris, pp. 549-54, Sept. 1987. (D)

[830] O.S. Scanlan and P.J. O'donovan, "Wave switched capacitor realization of low pass transfer function without finite transmission zeros," Proceeding of the European Conf. on circuit theory and Design, Paris, pp. 561-6, Sept. 1987. (D)

[831] T. Tron, "Parameter dependence and sensitivity in switched capacitor networks," Proceeding of the European conf. on circuit theory and Design, Paris, pp. 765-70, Sept. 1987. (A)

[832] Lu Yue Shen and Yong Chao, "A switched capacitor circuit simulation and optimization program," J. Electron., vol. 9, no. 5, pp. 395-403, Sept. 1987. (A)

[833] Y. Takeda and C. Sato, "Switched-capacitor block with two clock frequencies," Trans. Inst. Electron. Inf. Communi. Engg. A, vol. J70A, no. 9, pp. 1275-82, Sept. 1987. (A) 
[834] H. Quiting and W. Sansen, "Design technique for switched capacitor broad band, phase split networks," IEEE Trans. Circuits \& Syst., vol. 34, no. 9, pp. 1096-102, Sept. 1987. (D)

[835] K. Nakayhama and Y. Kuraishi, "Present and future application of switched-capacitor circuits," IEEE Circuits Devices Mag., vol. 3, no. 5, pp. 1021, Sept. 1987. (H)

[836] H. Onodera, T. Tateihi and K. Tamaru, "A cyclic switched capacitor A/ D and D/A converter," Electron. Communi. Jpn. 2 Electron., vol. 70, pp. 5665, Sept. 1987. (G)

[837] J.P. Atherton, "Sample correlation controlled by switched capacitor filters of the Digital Signal Processing," Proc. Int. Conf. Florence, Italy, pp. 365-8, Sept. 1987. (D)

[838] J. Rebega, "Switched capacitor filters for signal detection," Electron. Ind., no. 130, pp. 39-43, Sept. 1987. (D)

[839] E. Preiss, "Signal recognition using switched capacitor filters," IEEE no. 19, pp. 48-51, Sept. 1987. (D)

[840] G. Macor and J. Reberga, "Switched capacitor filters," Electron. Oggi., no. 49, pp. 159-64, Oct. 1987. (D)

[841] T.S. Rathore and B.B. Bhattacharyya, "A synthesis approach to the design of stray insensitive SC circuits from active RL or RLC prototype. Int. J. Circuit Theory \& Appl., vol. 15, no. 14, pp. 89. Oct. 1987. (D)

[842] S.S. Penbeci and K.M. Fidanboylue, "Switched capacitor high pass filter realization using the MLDD transformation," Int. J. Electron., vol. 63, no. 4, pp. 499-508, Oct. 1987. (D)

[843] J. Miluka, A. Konczkowaska and M. Bon, "Switched capacitor biquad with low influence of finite gain," Electron. Lett., vol. 23, no. 22, pp. 1198-9, Oct. 1987. (D)

[844] E.P. Nowick and W.M. Snelgrove, "Circuit and layout of a state multiplexed switched capacitor filter," CCVLSI-87, technical Digest Canadian Winning Man, Canada Univ., Oct: 1987. (D)

[845] U. Bernhardt, "Noise in SC integrator with real sampled and hold circuit," Nachr. Elektronik, vol. 37, no. 11, pp. 411-14, 1987. (B)

[846] J. Bourhay, "The mfs filters with switched capacitor," Toute Electron., no. 528 , pp. $78-82$, Nov. 1987 . (D)

[847] H. Matsumoto and K. Watanable, "Switched capacitor frequency to voltage and voltage to frequency converters," Trans. Inst. Electron. inf. Communi. Engg. E., vol. 70, no. 11, pp. 1044-5. Nov. 1987. (G)

[848] J.I. Sewell, "The SCNAP series of software for switched capacitor circuits design," IEE Colloquium on Analogue IC Design (Digest No. 94), London, pp. 10/1-5, Nov. 1987. (H)

[849] A.K. Bett, J.T. Taylor and D.G. Haigh, "On the design of switched capacitor FIR decimator and interpolator," IEE Colloquium on Analogue IC Design (Digest No. 94), London, pp. 8/1-5, Nov. 1987. (E)

[850] P. Zbinden and U. Fawer, "Chips: a fully automated mask generation for an SC ladder filter chip. Mitt. Agen., no. 40, pp. 21-7, Nov. 1987. (D)

[851] D.G. Haigh and J.T. Taylor, "On switch induced distortion in switched 
capacitor circuits," IEE Colloquium on Analogue IC Design (digest no. 94), London, pp. 7/1-5, Nov. 1987. (H)

[852] P.J. Sabourian and N.G. Dirdle, "A microprocessor controlled switched capacitor filter for biomedical applications," IEEE Montech Conf. Biomedical Technology, New York, USA, pp. 148-51, 10, Nov. 1987. (D)

[853] O. Matsubara, K. Yabuta, E. Sato and H. Takatori, "A switched capacitor line equalizer for digital subscriber loop transmission." GLOBECOM Tokyo IEEE/ IECE, pp. 1746-56, Nov. 1987. (H)

[854] A.K. Betts and J.T. Taylor, "Clocking schemes for switched capacitor FIR decimators." Electron. Lett., vol. 23, no. 24, pp. 1323-4, Nov. 1987. (E)

[855] J.C.M. Bermudez and B.B. Bhattacharyya, "Optimization of parasiticinsensitive switched capacitor biquads," IEE. Proc. Electron. Circuits \& Syst., vol. 134, no. 6, pp. 265-75, Dec. 1987. (D)

[856] L.E. Larson, "GaAs switched capacitor circuits for high speed signal processing," IEEE J. Solid State Circuits, vol. 22, no. 6, pp. 971-81, Dec. 1987. (H)

[857] K. Kondoh and K. Watanable, "Auto ranging switched-capacitor analog to digital converter," IEEE Trans. Intru. Meas., vol. 3, no. 5, pp. 10-21, Dec. 1987. (D)

[858] T. Fulop and M. Monteechi, "Switched capacitor ladder filters with offsetinsensitive time continuous feedback integrators," IEE Proc. G. Electron. Circuits Syst., vol. 134, no. 6, pp. 259-64, Dec. 1987. (G)

[859] H. Matumoto, H. Shimizu and K. Watanable, "A switched capacitor charge balancing analog to digital converter and its application to capacitance measurement," IEEE Trans. Instru. Meas., vol. 1M, no. 4, pp. 873-8, Dec. 1987. (G)

\section{8}

[860] J. Schwert, "Switched capacitor filter with microprocessor interface," Electron. Ind., vol. 19 , no. 19 , pp. 67-70, 1988. (H)

[861] Shen Lu Yue and Yong-Chao, "Nonideal switched capacitor micro model in the simulation of general switched capacitor networks," Model Simul. Control. A., vol. 18 , pp. 1, pp. 57-63, 1988. (A)

[862] U. Bernhardt, "Background noise of SC integrator with several inputs," Nachrtech. Elektronik, vol. 38, no. 11, pp. 48-11, 1988. (B)

[863] T. Dostal and M. Machat, "Switched capacitor biquad (active filter)," Elektrotech. Cas., vol. 39, no. 10, pp. 762-76, 1988. (D)

[864] Lu Yue and Shen Yong-chao, "Switched capacitor filter computer-aided design," Model Simula. Control A, vol. 18, no. 3, pp. 13-20, 1988. (D)

[865] A.S. Belmas, A.M. Danichev and Yu.S. Peritl'ev, "Sensitivity study of circuits with switched capacitor," Izv Vyssh. Uchebn Zaved Elektromekh., no. 12, pp. 60-65, 1988. (A)

[866] Liu Huifen and Yin Dacheng, "A channel layout algorithm study of marks networks design system for SC circuits," J. Tsinghua, Univ., vol. 24, no. 1, pp. 52-4, Jan. 1988. (A)

[867] K. Hibata, M. Emura and S. Yenoda, "High voltage switched capacitor circuit and application to tracking amplifier," Trans. Inst. Electron. Inf. Communi. Eng. C., vol. J71C, no. 1, pp. 10-17, Jan. 1988. (B) 
[868] D.L. Hornak, "Capacitor control relaying for switched capacitor banks. Rural Electric. Power Conf., (New York, USA IEEE), pp. 136/1-8, 1988. (H)

[869] E.M. Saad, "Analysis of switched-capacitor filters with nonideal op. amp," Model. Simulation. Control. A, vol. 16, no. 3, pp. 13-20, 1988. (D)

[870] J. Schwerte, "Switched capacitor associated with a microprocessor II," Electron. Ind., vol. 23 , no. 11 , pp. 100-2, 1988. (H)

[871] H. Wkier and R. Schmitz, "Multi-channel SC filter for variable middle frequency in the multiplexed operation," NTZ-fachber, vol. 103, pp. 197-202, 1988. (D)

[872] H. Yaghutiel, S. Shen, S. Sangiovanni-vincentelli and P.R. Gray, "Automatic layout of switched capacitor filter for custom applications," 1988 IEEE Int. symp. on solid state circuits conf., San Francisco, pp. 170, Feb. 1988. (D)

[873] M.J.M. Pelgrom and M. Roorda, "An algorithmic 15b CMOS digital to analog converter," 1988 IEEE Int. symp. on solid state circuits, San Francisco, pp. 198-9, Feb. 1988. (G)

[874] M. Kaneka, "A new state variable model for switched capacitor circuits MED equation," Trans. Inst. Electron. Inf. Communi. Eng. A, vol. J71A, no. 2, pp. 235-42, Feb. 1988. (H)

[875] M. Kaneka, "A new design method for a low sensitivity switched capacitor filters," Trans. Inst. Electron. Inf. Communi. Eng. A, vol. J71A, no. 2, pp. 24350, Feb. 1988. (D)

[876] Y. Jyo, K. Iwata, H. Nakao and S. Minamoto, "Switched capacitor fan filter," Trans. Inst. Electron. Inf. Communi. Eng. C, vol. J71C, no. 2, pp. 31316, Feb. 1988. (D)

[877] H. Matsumoto, "Switched capacitor charge balancing analog to digital its application to capacitance measurement," Res. Grad. Sch. Eletron. Sci. Technol. Shizuo Ka, Univ., no. 9, pp. 43-50, March 1988. (H)

[878] T. Inoue, F. Ueno and S. Sonoble, "Design of narrow band switched capacitor filter using new SC integrator with reduced capacitor spread," Trans. Inst. Electron. Inf. communi. Eng., vol. J72A, no. 3, pp. 618-20, March 1988. (D)

[879] C. Ikeda, Y. Horio and S. Mori, "SC bilinear based elimination ladder filters with extended biquads," Electron. Lett., vol. 24, no. 7, pp. 432-4, March 1988. (D)

[880] V.F. Dias and J.F. Da. Franca, "Parasitic compensated switched capacitor delay lines," Electron. Lett., vol. 24, no. 7, pp. 432-4, March 1988. (H)

[881] A. Cichocki and R. Unbehauen, "Switched capacitor function generator," Int. J. Electron., vol. 64, no. 3, pp. 359-75, March 1988. (H)

[882] H. Iwakura and S. Ihira, "A design of LDI ladder type SC filters using time share single op-amp," Trans. Inst. Electron. Inf. Communi. Eng. A, vol. J71A, no. 3, pp. 919-21, March 1988. (D)

[883] Lei Guang-pu, "Computer-aided analysis of SCN's with linear and nonlinear elements using capacitor switch micro model," Acta, Electron. Sin, vol. 16, no. 2, pp. 60-7, March 1988. (A)

[884] D.G. Nairn and A.S. Sedra, "Auto scan automated switched capacitor filter design program," IEEE Circuits Devices, Mag., vol. 4, no. 2, pp. 5-8, March 1988. (D) 
[885] A. Cichocki, "Monolithic MOS switched capacitor micro system for nonlinear analog signal processing," IEEE Trans. Instru. Meas., vol. 37, no. 1, pp. 18-24, March 1988. (A)

[886] A. Davari, "Current/voltage analysis SC networks," Proc. of the 20th Southern Symp. on System Theory. (Washington, DC, USA IEEE Comput. Soc. Press), March 1988. (A)

[887] A. Rodriguez-vazquez, A. Rueda, J.L. Huertas and R. Dominguez-casto, "Switched capacitor neural networks for linear programming," Electron. Lett., vol. 24 , no. 8, pp. 496-8, April 1988. (H)

[888] I. Sasaki and T. Kasai, "A consideration of the problem in switched capacitor realization of nonrecursive and recursive filters." Electron. Lett., vol. 64, no. 4, pp. 537-46, April 1988. (D)

[889] A. Kalin, "Exact systematic design of parasitic insensitive celluler, elliptic SC ladder filters, "Mitt. Agen., no. 47, pp. 9-16, April 1988. (D)

[890] W.W. Policuk and B.L. Rojo, "A note on statistical sensitivity computation in switched capacitor networks," IEEE Trans Circuits Syst., vol. 35, no. 4, pp. 423-5, April 1988. (A)

[891] M. Ishikawa, "A balance type switched capacitor biquads block realized with one op.amp.," Trans. Inst. Electron. Communi. Eng. A, vol. J71A, no. 4, pp. 956-6, April 1988. (D)

[892] J.C. Lin and J.H. Nevin, "Differential charge-domain bilinear switchedcapacitor pseudo N-path filters," IEEE Trans. Circuits \& Syst., vol. 35, no. 4, pp. 409-15, April 1988. (D)

[893] J.E. Da Franca and D.G. Haigh, "Design and applications of single path frequency translated switched capacitor filters," IEEE Trans. Circuits \& Syst., vol. 35, no. 4, pp. 398-408, April 1988. (D)

[894] Y. Horio, "Switched capacitor high pass laader filters using modified lessees discrete differentiator," Trans. Inst. Electron. Inf. Communi. Eng. E, vol. E71J, no. 4, pp. 375-87, April 1988. (D)

[895] I. Sasaki, S. Yoneda and T. Kasaki, "Phase synchronous type walsh analyzer using switched capacitor circuits," Trans. Inst. Electron. Inf. Communi. Engg. C, vol. J71C, no. 4, pp. 52-6. April 1988. (H)

[896] J.E. Da. Franca, "Multirate switched-capacitor system approach to frequency division multiplexing," Electron. Lett., vol. 24, no. 8, pp. 501-3, April 1988. (H)

[897] D.G. Haigh, C. Toumazou and S.J. Harrold, "Design optimization of a GaAs switched capacitor filter," IEE 1988 Saraga Colloquium on Electric Filters," Digest No. 77. London Uk, pp. 1/1-10, April 1988. (D)

[898] A.T. Younis and R.E. Massara, "On the design of optimal switchedcapacitor filter on the use of lossy frequency dependent negative resistance (FDNR) prototype structure," IEE 1988 Saraga Colloquium Electronic Filters Digest, no. 77, London Uk, pp. 2/1-10, May 1988. (D)

[899] A.K. Betts, J.T. Taylor and D.G. Haigh, "Investigation of switched-capacitor integrator-pair with low sensitivity to nonideal op amp effects," IEE colloquium on electronic filters Digest no. 77, London, pp. 3/1-11, May 1988. (D)

[900] Zhuo Bao-wei and Zeng-ping, "Exact design of biquadratic SCF branches 
and SFG in Z-domain," Acta. Electron. Sin., vol. 16, no. 3, pp. 71-8, May 1988. (D)

[901] J. Stefl, "Modified method of nodal voltage and its use for the analysis switched capacitor networks," Sdelovacia Tech., vol. 36, no. 5, pp. 177-9, May 1988. (A)

[902] N.J. Inglis and W.H. Holmes, "A programmable switched capacitor FIR filter," 7th Australia, Microelectronics conf. proc. Sydney NSW Australia, pp. 101-5, May 1988. (E)

[903] J. Helms, "Measurement of switched capacitor filters generated with silicon compiler," Proc. of IEEE, Custom Integrated Circuits Conf. Rochester, pp. 14.2/ 1-5, May 1988. (D)

[904] B.S. Song, "A $10.7 \mathrm{MHz}$ switched capacitor filter," Proc. of the IEEE 1988 Custom Integrated Circuits Conf. Rochester, pp. 1, 2, 3/1-4, May 1988. (D)

[905] K. Nagraj, "A novel parasitic insensitive switched capacitor technique for very large time constant," Proc. of the Custom Integrated Circuits Conf., Rochester, pp. 1, 2/4, May 1988. (A)

[906] C.C. Shin and S.Y. Sun, "Jitter attenuation phase locked loop using switched capacitor controlled crystal oscillator," Proc. of the IEEE Custom Integrated Circuits Conf. Rochester, pp. 9.5/1-3, May 1988. (C)

[907] L.B. Wolovitz and J.I. Sewell, "General analysis of large scale linear switched capacitor networks," IEE Proc. G. Electron. Circuits Syst., vol. 135, no. 3, pp. 119-24, June 1988. (A)

[908] A. Hyogo and K. Sekie, "A synthesis of current source using SC circuit and its application to filters," Trans. Inst. Electron. Inf. Communi. Engg. C, vol. J71C, no. 6, pp. 797-801, June 1988. (D)

[909] M. Horita, Y. Iijima and G. Yamamoto, "A simulation method of grounded inductance by using SC circuits using half rate switched capacitor," Trans. Inst. Electron. Inf. Communi. Engg. C, vol. J71C, no. 6, pp. 802-9, June 1988. (F)

[910] S. Fotopoulos and A. Limperis, "A systematic design and properties of fully differential switched capacitor biquad," Int. J. Electron., vol. 65, no. 1, pp. 67-80, June 1988. (D)

[911] C.W. Solomon, "Switched capacitor filters compact inexpensive," IEEE. Spectr, vol. 25 , no. 6 , pp. 28-32, June 1988. (D)

[912] D. Cormier, "Tuning in with switched capacitor filter ICs," ESD Electron. Syst. Des. Mag., vol. 18, no. 7, pp. 45-50, June 1988. (D)

[913] G.W. Robert and A.S. Sedra, "Switched capacitor ladder networks derived from general parameter bandpass LC ladder networks," 1988 IEEE Int. symp. on circuits and systems. Proceeding, Espoo, Finland, pp. 1005-6, vol. 2, June 1988. (D)

[914] F. Montecchi and A. Premoli, "Performance of band pass cascaded switched capacitor filters with reduced pole Q," 1988 IEEE Int. symp. on circuits and systems. Proceeding, Espoo, Finland, pp. 1253-6, vol. 2, June 1988. (D)

[915] Q. Hung, "A novel technique for the reduction of capacitance spread in high-Q switched capacitor circuits," 1988 IEEE Int. symp. on circuits and systems, Proceeding, Espoo, Finland, pp. 1249-52, June 1988. (D)

[916] T. Inoue, F. Ueno, S. Sonobe and T. Matsumoto, "Design of very low 
sensitivity fully differential band pass switched capacitor filters," 1988 IEEE Int. symp. on circuits and systems. Proceeding, Espoo, Finland, pp. 1245-49, June 1988. (D)

[917] J.S. Tong and Y.C. Tong, "A switched capacitor time division multiplexed pole sharing technique for linear phase band pass filter bank," 1988 IEEE Int. symp. on circuits and systems, Proceeding, Espoo, Finland, pp. 1253-4, June 1988. (D)

[918] A.M. Davis and H.P. Naguyen, "Exact synthesis of switched capacitor filters using forward difference integrator," 1988 IEEE Int. symp. on circuits and systems, Proc., Espoo, Finland, pp. 1009-12, June 1988. (D)

[919] K. Chen and S. Eriksson, "Z-domain synthesis of switched capacitor LDI ladder filters," 1988 IEEE Int. symp. on circuits and systems. Proceeding, Espoo, Finland, pp. 1013, vol. 2, June 1988. (D)

[920] T. Jarska, O Vainio and Y. Neuvo, "GaAs MOSFET switched capacitor linear median hybrid filters," 1988 IEEE Int. symp. on circuits and systems. Proceeding, Espoo, Finland, pp. 1461-4, June 1988. (D)

[921] D.G. Haigh and J.T. Taylor, "High frequency switched capacitor filters for CMOS technology," 1988 IEEE Int. symp. on circuits and systems. Proc. Espoo, Finland, vol. 2, pp. 1469-72, June 1988. (D)

[922] M. Nalecz and J.J. Mulawka, "Parasitic compensated building blocks for active switched capacitor," 1988 IEEE Int. symp. on circuits and systems. Proc., Espoo, Finland, pp. 1483-6, vol. 2, June 1988. (A)

[923] F. Montecchi, "On the design of switched-capacitor filters with the voltage inverter switched approach," 1988 IEEE Int. symp. on circuits and systems. Proceeding, Espoo, Finland, pp. 1479-82, vol. 2, June 1988. (D)

[924] A. Limperis and I. Haritantis, "Wave SC filter based on two-ports equivalents," 1988 IEEE Int. symp. on circuits and systems, Espoo, Finland, pp. 101316, vol. 2, June 1988. (D)

[925] R.K. Henderson and J.I. Sewell, "Matrix method for switched capacitor filter design," 1988 IEEE'Int. symp. on circuits and systems, Proceeding, Espoo, Finland, pp. 1021-4, vol. 2, June 1988. (D)

[926] Y. Horio, S. Nakamura, H. Milyasaka, H. Takase, "Speech recognition networks with switched capacitor neuron type components," 1988 IEEE Int. symp. on circuits and systems, Proceeding, Espoo, Finland, pp. 495-8, vol. 1, June 1988. (H)

[927] B.G. Lofmark, "SC filter structures with reduced requirements on op amp bandwidth and setling time," 1988 IEEE Int. symp. on circuits and systems. Proceeding, Espoo, Finland, pp. 1473-7, vol. 2, June 1988. (H)

[928] H. Iswakura, "Realization of leapfrog type switched capacitor filters using time shaped op. amp," Trans. Inst. Electron Inf. Communi. Engg., vol. J71A, no. 7, pp. 1390-7, June 1988. (D)

[929] A. Opal and J. Vlach, "Analysis and design of nonideal switched capacitor networks," 1988 IEEE Int. symp. on circuits and systems, Proceeding, Espoo, Finland, pp. 1717-20, vol. 3, June 1988. (A)

[930] D.G. Haigh and J.T. Taylor, "On switched induced distortion in switched capacitor circuits," 1988 IEEE Int. symp. on circuits and systems, Proc. Espoo, Finland, pp. 1987-90, vol. 3, June 1988. (A) 
[931] L. Toth and E. Simonyi, "Computer aided analysis of general RSC circuits containing capacitive loops," 1988 IEEE Int. symp. on circuits and systems, Proceeding, Espoo, Finland, pp. 1991-4, vol. 3, June 1988. (A)

[932] W.J. Wolski, "Influence of op amp nonlinearity and switched-on resistance on switched capacitor integrator," 1988 IEEE Int. symp. on circuits and systems, Proceeding, Espoo, Finland, pp. 1995-8, vol. 3, June 1988. (A)

[933] K. Suyama and S.C. Fan, "A sensitive steady state discriminator function for nonlinear switched networks with application to SCN's containing signal controller switches," Int. symp. on circuits and systems, Proc. Espoo, Finland, pp. 2003-7, vol. 3, June 1988. (A)

[934] A. Puerto-Notario and M. Sanz-Postils, "Exact analysis of non-ideal switched capacitor networks through op amp asymptotic modelling," 1988 IEEE Int. symp. on circuits and systems, Proceeding, Espoo, Finland, pp. 2467-70, vol. 3, June 1988. (A)

[935] M.F. Fahmy, M.Y. Makkey and M.I. Sobhy, "Compensation for amplifier finite bandwidth in the design of switched capacitor networks," 1988 Int. symp. on circuits and systems, Proc., Espoo, Finland, pp. 2471-5, vol. 3, June 1988. (A)

[936] M. Kowalaski'and S. Bek, "Stability analysis of linear active circuits containing periodically switched resistors," 1988 IEEE Int. symp. on circuits and systems, Proceeding, Espoo, Finland, pp. 389-92, vol. 2, June 1988. (A)

[937] T. Fulop and F. Montecchi, "Switched capacitor biquad building block with offset insensitive time continuous feedback integrators," 1988 IEEE Int. symp. on circuits and systems, Proc. Espoo, Finland, pp. 1257-60, June 1988. (A)

[938] J. Silva-Martinez and E. Sanchez-Sinencio, "A spring SC filter design approach with reduced transmission Zero," 1988 IEEE Int. symp. on circuits and systems, Proceeding, Espoo, Finland, pp. 1727-4, vol. 2, June 1988. (D)

[939] R.P. Sigg, A. Kaelin, A. Muralt, W.C. Black and Jr. G.S. Moschytz, "Automated SC filter generation with a CMOS gate array type filter chip," 1988 IEEE Int. symp. on circuits and systems, Proceeding, Espoo, Finland, pp. 17258, vol. 2, June 1988. (D)

[940] Y. Fukui, N. Yabuki and A. Kosaka, "New S-Z transformation and its switched capacitor realization," 1988 IEEE Int. symp. on circuits and systems, Proceeding, Espoo, Finland, pp. 1999-2002, June 1988. (A)

[941] H. Matsumoto and K. Watanable, "Switched capacitor frequency to voltage and voltage to frequency converters based on charge balancing principle," 1988 IEEE Int. symp. on circuits and systems, Proceeding, Espoo, Finland, pp. 22214, June 1988. (A)

[942] Z. Qian and Z.G. Shen, "Switched capacitor networks with zero amplifier finite gain sensitivity," 1988 IEEE Int. symp. on circuits and systems, Proceeding, Espoo, Finland, pp. 2225-8, vol. 3, June 1988. (A)

[943] T. Ono, "An improved switched capacitor inductance simulation circuit using unity gain buffer," 1988 IEEE Int. symp. on circuits and systems, Proceeding, Espoo, Finland, pp. 2237-9, vol. 3, June 1988. (G)

[944] A.K. Bett, J.T. Taylor and D.G. Haigh, "Synthesis method for FIR decimators and interpolators," 1988 IEEE Int. symp. on circuits and systems, Proceeding, Espoo, Finland, pp. 2463-6, June 1988. (E)

[945] I. Sasaki, K. Matsui and S. Yoneda, "Switched capacitor realization of a 
walsh transformation circuits and its application to sequence filtering," 1988 IEEE Int. symp. on circuits and systems, Proceeding, Espoo, Finland, pp. 2477-80, June 1988. (D)

[946] Z. Kaelin and G.S. Moschytz, "Exact design of arbitrary parasitic insensitive elliptic SC ladder filters in Z-domain," 1988 IEEE Int. symp. on circuits and systems, Proceeding, Espoo, Finland, pp. 2484, vol. 3, June 1988. (D)

[947] M. Kaneko, "A systematic design for switched capacitor networks based on discrete time and state equation," Electron. Communi. Jpn, vol. 71, no. 7, pp. 10-21, July 1988. (A)

[948] U. Weder, "Switched capacitor filter design with stray insensitive building blocks," Wiss. Z. Tech. Dresd., vol. 36, no. 6, pp. 133-51, July 1988. (D)

[949] B. Kroemer, "Noise behavior of integrated switched capacitor filters with OTA," AEU, vol. 42, no. 4, pp. 209-16, July 1988. (D)

[950] A. Dabromator, "Switched capacitor interpolators and decimators using voltage inverter switches," AEU, vol. 42, no. 4, pp. 217-26, July 1988. (H)

[951] S.J. Harrold, "Switch-driver circuit suitable for high order switched capacitor filters implemented in GaAs," Electron. Lett., vol. 24, no. 15, pp. 982-4, July 1988. (D)

[952] U.V. Wali and R.N. Pal, "The new topology for realization of Z-domain transfer function of switched capacitor networks for adaptive filtering," J. Inst. Electron. Telecommuni. Engg., vol. 34, no. 4, pp. 281-5, August 1988. (A)

[953] I. Nagy, M. Bourahia and J. Megyeri, "DC chopper operating on switched capacitor concept," Elektrotechnika, vol. 81, no. 8, pp. 283-91, August 1988. (H)

[954] E. Hayahara and S. Hirano, "SCF realization based on simulation of LC filters," Bull Nagoya Inst. Technol., vol. 39, pp. 239-45, August 1988. (D)

[955] J. Goette and W. Guggenbuhl, "Noise performance in SC integrators assuming different OTA models," IEEE Trans Circuits \& Systems, vol. 35, no. 4, pp. 1024-8, August 1988. (B)

[956] Chen Keping, "Design of switched capacitor LDI ladder filter based on two port flow graph synthesis," Int. J. Circuit theory Appl., vol. 16, no. 3, pp. 335-42, August 1988. (D)

[957] P.M. Van. Peteghem, "On the relationship between PSRR and clock feed through in SC filters," IEEE, J. Solid State Circuits, vol. 23, no. 4, pp. 997-1004, August 1988. (D)

[958] S.S. Rofail, "Resistance realization using switched capacitor, devices and low temperature effects," Int. J. Electron., vol. 62, no. 2, pp. 233-41, August 1988. (F)

[959] S.D. Sharma, J.T. Taylor and D.G. Haigh, "Stray free second order circuits for correction sample and hold amplitude distortion in switched capacitor filters," Electron. Lett., vol. 22, no. 16, pp. 1007-8, August 1988. (D)

[960] J.E. Da. Franca, "FIR switched capacitor decimators with active delay block polyphase structures," IEEE. Trans. Circuits \& Syst., vol. 35, no. 8, pp. 1033-7, August 1988. (E)

[961] G. Espinosa Flores-verded and F. Montecchi, "SC circuit for very large and accurate time constant integrators with low capacitance ratios," Electron. Lett., vol. 24, no. 16, pp. 1025. August 1988. (B)

[962] E.A. Dmitriyev, V.A. Yerilov, and Yu.A. Yants, "A parametric filter with 
switchable capacitor," Telecommuni. Radio. Eng. 2, vol. 42, no. 1, pp. 104-6, August 1988. (D)

[963] V.F. Dias, J.E. Da. Franca and J.C. Vital, "High speed digital to analogue converter using passive switched conversion," Electron. Lett., vol. 24, no. 17, pp. 1063-5, August 1988. (G)

[964] Chung-Yu Wu, Tsai-Chung Yu, and Shin-Chi Chang, "Realization of FIR and IIR filter using SC differentiator," Tokyo Japan Business Centre for Academic Soc., pp. 99-100, August 1988. (F)

[965] M.M. Bodurova, G.A. Nenov and K.P. Stantchev, "An algebraic approach for sensitive analysis of single flow graph synthesized SC filters," Proc. of 8th Colloquia on Microwave Communi., Budapest, pp. 213-14, August 1988. (D)

[966] Li Lin., Xiachan Xu and Ninghua Zhou, "Two new algorithms for the analysis of general switched capacitor networks with nonideal op-amp," Midcon 88 Conf. Record, Dallas, Ventura, Electron. Convention Manage., pp. 55-8, August 1988. (A)

[967] S.T. Miroshnichenko, "Comparative analysis of two dimensional SC and CCD filters," Radio Electron. Communi. Syst., vol. 31, no. 5, pp. 92-4, 1988. (D)

[968] J. Schwerte, "Switched capacitor filters with microprocessor interface-II," Electron. Ind, vol. 19, no. 7, pp. 42-4, 1988. (D)

[969] C. Toumazou and D.G. Haigh, "Some design and characterization method for GaAs operational amplifier for switched capacitor applications," Electron. Lett., vol. 24, no. 18, pp. 1170-2, Sept. 1988. (B)

[970] Y. Takedo and C. Sato, "Second order switched capacitor filter blocks with two clock frequencies and its design," Trans. Inst. Electron. Inf. Communi. Engg., vel. J71A, no. 9, pp. 1682-8, Sept. 1988. (D)

[971] S. Kitamori, and Y. Magara, "Transient bias switched-capacitor amplifier," Trans. Inst. Electron. Inf. Communi. Engg., vol. J71A, no. 9, pp. 1760, Sept. 1988. (B)

[972] W.J. Wolska, "Gain bandwidth effect in biquadratic SC filters," Electron. Telecommuni. Lett., vol. 2, no. 4, pp. 35-45, Sept. 1988. (D)

[973] T. Inoue, "Switched capacitor filter," System Control, vol. 32, no. 9, pp. 500-6, Sept. 1988. (D)

[974] J. Schwertz, "Switched capacitor filter with microprocessor interface," Electron. Prox, vol. 23, no. 10, pp. 46-55, Oct. 1988. (D)

[975] M.F. Fahmy and M. Abo-zahhad, "Design of selective linear phase band pass switched capacitor filters with equiripple pass band amplifier response," IEEE Trans. Circuits \& Syst., vol. 35, no. 10, pp. 1220-9, Oct. 1988. (D)

[976] D. Raic, D. Strle, J. Tronteli and L. Tronteli, "Data structure for automatic design of a SC structure," Elektrotech. Vestn, vol. 55, no. 3, pp. 175-80, Oct. 1988. (A)

[977] M. Nakamura, "SC gyrator using UGB's,," Trans. Inst. Electron. Inf. Communi. Engg. A, vol. J71A, no. 10, pp. 1988-90, Oct. 1988. (F)

[978] C. Jain and D. Hyland, "A switched capacitor biquad filter," Microelectron. J., vol. 19, no. 5, pp. 35-8, Oct. 1988. (D)

[979] J. Schwertz, "Pass office," (SC filter) Elektron. Prox., vol. 23, no. 11, pp. 194-9, Nov. 1988. (D) 
[980] D. Biolek, "Calculation of system function of SC circuits excited in both phase," Slabop. Obz, vol. 49, no. 4, pp. 193-4, Nov. 1988. (A)

[981] J. William and B. Huffman, "Switched capacitor networks simplified DC/ DC converters design," EDN, vol. 33, no. 24, pp. 171-5, Oct. 1988. (G)

[982] A. Baruo, "New Q enhance SC biquad," J. Inst. Electron. Telecommuni. Engg., vol. 134, no. 6, pp. 457.8, Dec. 1988. (D)

[983] T. Inoue, F. Ueno and S. Sonobe, "Switched capacitor building block for fuzzy logic and neural networks," Trans. Inst. Electron. Inf. Communi. Engg, vol. E71, no. 12, pp. 1259-60, Dec. 1988. (A)

[984] C.A. Laber and P.R. Gray, "A positive feedback transconductance amplifier with high frequency high-Q CMOS switched capacitor filters," IEEE J. Solid State Circuits, vol. 23, no. 6, pp. 1370-8, Dec. 1988. (D)

[985] K. Kato, K. Kubota and T. Takebe, "Variable switched-capacitor band pass, band elimination filter and all pass network with low sensitivity," Trans. Inst. Electron. Inf. Communi., vol. J71A, no. 12, pp. 2120.30, Dec. 1988. (D)

[986] G. Chiappano, A. Colamonico, A. Donati, F. Maloberti and F. Montecchi, "A tunable switched capacitor programmable N-path receiver and generator," IEEE J. Solid State Circuits, vol. 23, no. 6, pp. 1418-25, Dec. 1988. (H)

1989

[987] R. Unbehauen, "Designing a class of switched capacitor filters," Nachr. Elektronik, vol. 39, no. 2, pp. 53-5, 1989. (D)

[988] K. Halonen, "High frequency switched capacitor circuit design," Acta. Polytech. Engg. Ser., no. 164, pp. 186-97, 1989. (A)

[989] S. Signell and K. Mossberg, "Offset compensation of two phase switched capacitor filters," IEEE Trans Circuits \& Syst., vol. 36, no. 1, pp. 31-41, Jan. 1989. (D)

[990] K. Shiata, M. Emura and S. Yoneda, "Fast settling high gain GaAs op amp switched capacitor applications," Electron. Communi. Jpn. 2 Electron., vol. 72, no. 1, pp. 1-10, Jan. 1989. (A)

[991] M.E. Zaghloul and A.E. Said, "Stray free switched capacitor loop biquad," J. of the Franklin. Inst., vol. 326, no. 2, pp. 237-9, 1989. (D)

[992] H. Matsumoto, "A quasi passive switched capacitor frequency to voltage converter," Trans. Inst. Electron. Inf. Communi. Engg. E, vol. E72, no. 1, pp. 10-12, Jan. 1989. (F)

[993] C.A. Avratogloue, N.C. Voulgaris and F.I. Ioannidou, "Effects of parallel switched capacitance on the performance of a class E tunned power amplifier with finite switch," Model. Simul. Control. A, vol. 22, no. 3, pp. 51-69, 1989. (B)

[994] U. Beranadt and H. Unger, "Scanning noise of switched-capacitor double integrators," Nachr. Elektronik, vol. 39, no. 10, pp. 381-3, 1989. (B)

[995] A. Petraglia and S.K. Mitra, "An exact programmable switched-capacitor equalizer," 22 Asilomar Conf. on Signal, Systems \& Computer, Pacific Grove, pp. 142-5, vol. 1, 1988. (H)

[996] D. Watson, "Principal and application of switched capacitor filters introduction to the field of filter circuits," Elektronik, vol. 38, no. 24, pp. 64-5, 1989. (D) 
[997] D. Watson and W. Lehbrink, "The principal and application of switched capacitor filter, higher grade filters and practical circuits," Elektronik., vol. 38, no. 10, pp. 729-37, 1989. (D)

[998] U. Bernhardt, "Scanning noise in first order SC filters," Nachr. Elektronik, vol. 39, no. 9 , pp. 344-8, 1989. (D)

[999] A. Olse, H. Vander Lipper, P. Jarron, F. Anghinolfi and E. Heijine, "Switched capacitor analog storage line," Geneva Switzerland: Cern, pp. 678-9, 1989. (D)

[1000] S.P. Shien, C.K. Wang, R. Castello and P.R. Gray, "A sealable switched capacitor filter implement in 1.2um technology," IEEE J Solid State Circuits, vol. 24, no. 1, pp. 174-7, Feb. 1989. (D)

[1001] Quieting Huang, "A novel technique for the reduction of capacitor spread in high Q SC circuits," IEEE Trans. Circuits \& syst., vol. 36, no. 1, pp. 121-6, Feb. 1989. (A)

[1002] K. Nakayama and M. Ichihara, "A multi level data transmission base band LSI using SC biquad," Trans. Inst. Electron. Inf. Communi Engg. A, vol. 72 , no. 2 , pp. 251-4, Feb. 1989. (D)

[1003] Chung-yu-wu and Tsai-chung Yu, "New monolithic switched capacitor differentiator with good noise rejection," IEEE J. Solid State Circuits, vol. 4, no. 1, pp. 177-80, Feb. 1989. (B)

[1004] A. Hyeogo and K. Sekine, "A synthesis of reduced ripple switched capacitor current source and their application," Trans Inst. Electron. Inf Communi Engg., vol. J72C, no. 2, pp. 95-100, Feb. 1989. (A)

[1005] T. Komazaaki and K. Gunjii, "Study on biquad SCF," Trans Inst Electron Inf. Communi Engg., vol. 72A, no. 2, pp. 294-301, Feb. 1989. (D)

[1006] K. Nakayama and M. Ichihara, "A multi level data transmission base band LSI using SC biquad," Trans Inst. Electron. Communi. Engg. A, vol. J72A, no. 2, pp. 251-6, Feb. 1989. (D)

[1007] N.C. Changkakati, "Z-to-S transformation nonuniqueness in tunable switched capacitor filter response evolution and a digital tunable band pass," IEEE Trans Instrum. Mes., vol. 38, no. 1, pp. 126-8, Feb. 1989. (D)

[1008] D.G. Haigh and J.T. Taylor, "Continuous-time and switched capacitor monolithic filter based on current and charge simulation," IEE Colloquium on Current Mode Analogue Circuits (Digest no. 35) London Uk, pp. 3/1-5, Feb. 1989. (D)

[1009] D. Biolek, "(SCSK)-programmable for the analysis of switched capacitor circuits," Slabop. Obz, vol. 50, no. 3, pp. 112-17, March 1989. (A)

[1010] A. Hygo and K. Sekine, "SC immittance simulation circuit using UGB's and their application to filters," Trans IEICE, vol. J22A, no. 3, pp. 535-40, March 1989. (F)

[1011] A. Davari and C.A. Halijak, "Multiple switched capacitor and comb filters," The twenty first southeastern symp. on systems theory, Tallahassee, pp. 604-7, March 1989. (D)

[1012] "Simplification of the Switched capacitor circuit description to a minimum," Slabop. Obz, vol. 50, no. 3, pp. 148-50, March 1989. (A)

[1013] G. Palmisano and F. Montecchi, "Simplified pseudo N-path cell for Z to 
Z-transform and SC active," IEEE Trans Circuits \& Syst., vol. 36, no. 3, pp. 4613, March 1989. (H)

[1014] I. Ooto, F. Ueno and T. Inoue, "Analysis of a switched capacitor transformer with a large voltage transformer ratio and its applications," Trans. Inst. Electron. Inf. Communi. Engg., vol. J72C-II, no. 3, pp. 195-203, March 1989. (A)

[1015] I. Sasaki, S. Yoneda and T. Kasai, "Phase synchronous type walsh analyzer using switched capacitor circuit," Electron. Communi. Engg. Jpn. 2., vol. 25, no. 3, pp. 42-9, March 1989. (H)

[1016] A. Dabrowski and G.S. Moschytz, "Direct by-inspection derivative of signal flow graph for multi phase stray sensitive switched capacitor filter," Electron., pp. 387-9, March 1989. (D)

[1017] W.H. Ki and G.C. Temes, "Switched capacitor modulator circuits," Electron. Lett., vol. 25, no. 6, pp. 379-86, March 1989. (H)

[1018] T. Inoue, F. Ueno, T. Matsumoto and S. Sonobe, "Switched capacitor circuit analysis program SCNDAL and its application to SC filter design," Trans. Inst Electron. Communi. Engg., vol. 72, no. 3, pp. 525-7, March 1989. (D)

[1019] J. Goette and C.A. Gobet, "Exact noise analysis of SC circuits and an approximate computer implementation," IEEE Trans Circuits \& syst., vol. 36, no. 4, pp. 508-21, April 1989. (D)

[1020] T. Inoue, F. Ueno and S. Sonobe, "A synthesis of low sensitivity high Q band pass switched capacitor filter," Trans. Inst. Electron. Inf. Communi. Engg. E, vol. E72, no. 4, pp. 340-2, April 1989. (D)

[1021] J-An Gong and Zhi-Guang Shen, "A switched capacitor micro model approach to the computer aided analysis of switched capacitor networks," IEEE Trans Circuit \& System, vol. 36, no. 4, pp. 497-507, April 1989. (D)

[1022] P.M. Van Peteghem, J.F. Dugue-Carrillo and E. Sanchez-Sinencio, "Optimization of SC filter for high frequency application," IEEE Trans. Circuits \& Syst., vol. 36, no. 4, pp. 83-8, April 1989. (D)

[1023] H. Tang and R.J. Mack, "Fault diagnosis of switched capacitor circuits," IEE Colloquium VLSI Analogue Design (Digest-66) London Uk, IEE, pp. 8/14, April 1989. (H)

[1024] J. Silva-Martinez and E. Sanchez-Sinencio, "Biquadratic programmable SC filter with additional flexibility and reduced total capacitance," Int. J. Circuit theory \& Appl., vol. 17, no. 2, pp. 24-8, April 1989. (D)

[1025] F. Goodenough, "For filtering its switched capacitor IC," Electron. Des., vol. 37, no. 8, pp. 77-80, April 1989. (D)

[1026] M. Van Pacmel, "Interface circuit for capacitive accelerometer," Sens. Actuator, vol. 17, no. 3-4, pp. 627-37, May 1989. (H)

[1027] J.C. Giorgi, "Switched capacitor filters, the new generation," Toutte Electron., no. 544, pp. 38-41, May 1989. (H)

[1028] A.E. Said, "Novel drift-fully differential switched capacitor based on the simulation of ladder structure," Int. J. Electron., vol. 66, no. 5, pp. 801-5, May 1989. (D)

[1029] U. Menzi and A. Gubser, "Minimum frequency shift keying receiver in switched capacitor technique," Mitt. Agen, no. 49, pp. 37-43, May 1989. (H) 
[1030] O. Hanagata and M. Tanaka, "Numerical analysis of switching transformation matrix for SC circuits," Trans. Inst. Electron. Inf. Communi. Engg. A, vol. J72A, no. 5, pp. 770-7, May 1989. (A)

[1031] K. Martin, "Nonfiltering applications of switched capacitor," 1989 IEEE Int. conf. on circuits and systems, Portland, USA, pp. 162, vol. 1, May 1989. (D)

[1032] P.J. Hurst and J.T. Brown, "Finite impulse response switched capacitor decimator filters for the DSMD/A interface," 89 IEEE Int. Symp. on Circuits \& Systems, Portland, USA, pp. 1688-91, vol. 3, May 1989. (E)

[1033] D.G. Haigh and J.T. Taylor, "Continuous-time and switched capacitor monolithic filters based on current and charge simulation," 89 IEEE Int. Symp. on Circuits \& Systems. Portland, USA, pp. 1580-3, vol. 3, May 1989. (D)

[1034] R.P. Martins, "A N-path order IIR switched capacitor decimator building block with optimum implementation," 89 IEEE Int. Symp. on Circuits \& Systems, Portland or New York, vol. 2, pp. 1471-4, May 1989. (E)

[1035] A. Robertini and J. Goette, "Nonlinear distortion in SC integrator due to nonideal switches and amplifier," 89 IEEE Int. Symp. on Circuits \& Systems, Portland or New York, pp. 1692-5, vol. 3, May 1989. (B)

[1036] M. Sawahashi and K. Murota, "Variable band width-filter using SCF and MOSFET-C filter," 89 IEEE Int. Symp. on Circuits \& Systems, Portland or New York, pp. 1495-8, vol. 2, May 1989. (D)

[1037] D.G. Haigh, "Design and optimization of switched capacitor filter," 89 IEEE Int. Symp. on Circuits \& Systems. Portland or New York, pp. 1499-8, vol. 2, May 1989. (D)

[1038] G. Fischer, "A switched capacitor building block for analog FIR filters," Int. Symp. on Circuits \& Systems, Portland or New York, pp. 1445-8, vol. 2, May 1989. (E)

[1039] J. Goette, A. Kaelin and W. Guggenbuw, "Criteria and methods for the selection of optimized capacitor value in SC-filters," 89 IEEE Int. Symp. on Circuits \& Systems, Portland or New York, pp. 1696-700, vol. 3, May 1989. (D)

[1040] P.V. Anand Mohan, "Exact design of LDI type ladder filters," Int. Symp. on Circuits \& Systems, Portland or New York, pp. 1701-4, vol. 3, May 1989. (D)

[1041] C. Toumazou, D.G. Haigh and O. Richards, "Fast settling GaAs op. amps. for switched capacitor applications," 89 IEEE Int. Symp. on Circuits \& Systems, Portland or New York, pp. 659-62, vol. 1, May 1989. (H)

[1042] P.M. Van. Peteghem, "Improved clock buffer with high PSRR for SC circuits applications," 89 IEEE Int. Symp. on Circuits \& Systems, Portland or New York, pp. 1705-8, vol. 3, May 1989. (B)

[1043] T. Ono, "A two phase clock controlled SC inductance simulation circuit realized with one unity gain buffer," 89 IEEE Int. Symp. on Circuits \& Systems, Portland or New York, pp. 1709-11, vol. 3, May 1989. (F)

[1044] I. Chang Jou, Rau Lilu, and Chung-Yu, "The characteristic comparison of fully differential switched capacitor biquads," 89 IEEE Int. Symp. on Circuits \& Systems, Portland, pp. 1712-15, vol. 3, May 1989. (D)

[1045] G. Palmisane and F.V.G. Espinosa, "Performance comparison of pseudo $\mathrm{N}$-path SC cells in filters real operation amplifier," 89 IEEE Int. Symp. on Circuits \& Systems, Portland, pp. 1467-70, vol. 2, May 1989. (D) 
[1046] Wu Chung-Yu and Tsai-Chaug Yu, "The design of high pass and band pass ladder filters using novel differentiator," 89 IEEE Int. Symp. on Circuits \& Systems, Portland, pp. 1463-6, vol. 2, May 1989. (D)

[1047] Y. Hario, H. Takase and S. Nakamura, "Switched capacitor pre-processor for speech processing using SC CIC filter," 89 IEEE Int. Symp. on Circuits \& Systems, Portland, or New York, pp. 1311-14, vol. 2, May 1989. (D)

[1048] A. Dabrowski, "Offset compensated switched capacitor delay circuit that insensitivity to stray capacitance and capacitor mismatch," Electron. Lett., vol. 25, no. 10 , pp. $623-5$, May 1989 . (H)

[1049] K.A.A. Albidiweihy, "A decomposition approach for fault diagnosis of switched-capacitor circuits," 89 IEEE Int. Symp. on Circuits \& Systems, Portland, pp. 1716-19, vol. 3, May 1989. (H)

[1050] D. Giannupoulos, S. Wong and A. Lish, "Functional level simulation of switched capacitor circuit with nonideal switches," Proc. the IEEE Custom Integrated Circuits, San Diego, pp. 21-2/1-4, May 1989. (A)

[1051] T. Adachi, A. Bariow, K. Takasuka and Y.N. Namba, "Integrated switched capacitor filter design system," Proc. of the IEEE Custom Integrated Circuits Conf., San Diego, pp. 4-5/1-5, May 1989. (D)

[1052] I.S. Abukhater and E.I. EI-Masry, "A novel BIMOS switch for use in switched capacitor filters," Proc. of the IEEE custom Integrated Circuits Conf., San Diego, pp. 77/1-4, May 1989. (D)

[1053] Chung-Yu Wu and Tsai-Chung Yu, "New forward and backward mapping SC differentiator and their application in the design of biquads SCF," Int. Symp. on VLSI technology, Systems and Application, Taiwan, pp. 169-73, May 1989. (D)

[1054] F. Ueno, T. Inoue, K. Sugitani and S. Araki, "A programmable switched capacitor circuit for multivalued to binary and binary to multivalued conversion," The Nineteenth Int. Symp. on multiple-value logic, Guangzhou, China, pp. 198201, May 1989. (H)

[1055] R. Raut, B.B. Bhattacharyya and S.M. Faruque, "An application of array design architecture to switched capacitor filter circuit," 89 Int. on ASSP., Glasgow, vol. 4, pp. 2401-4, May 1989. (D)

[1056] J.C. Chang and Y.C. Tong, "A low power time multiplexed SC speech spectrum analyzer," 1989 Symposium on VLSI Circuits Digest of technical paper Kyoto, Japan, pp. 91-2, May 1989. (H)

[1057] K. Kondo and K. Watanable, "A switched capacitor interface for capacitive sensor with wide dynamics range," IEEE Trans Instr. \& Meas., vol. 38, no. 3, pp. 736-9, June 1989. (H)

[1058] M.J. Svihara and B. Newrouziam, "A new approach to the design of bilinear-LDI switched capacitor filters having low pass sensitivity," IEEE Pacific Rim Conf. on Communi. Computer \& Signal Processing, Victoria, pp. 193-89, June 1989. (D)

[1059] R.A. Quinnel, "Switched capacitor filter ICs," EDN, vol. 35, no. 1, pp. 86, June 1989. (D)

[1060] T. Komazaki and K. Gunji, "A study on biquad SCF with one operational amplifier," Trans. Inst. Electron. Inf. Communi. Engg. A, vol. J72A, no. 6, pp. 945-9, June 1989. (D) 
[1061] A. Hyogo and K. Sekine, "A synthesis of reduced ripple switched-capacitor current source and their application," Electron. Communi. Jpn. 3 Fundam. Electron, vol. 72, no. 10, pp. 70-6, June 1989. (H)

[1062] A. Limperis and I. Haritntis, "SC filter based on scattering parameters," Int. J. Circuit theory Appl., vol. 17, no. 3, pp. 347-61, July 1989. (D)

[1063] J.E. Da. Franca and V.F. Dias, "Efficient switched capacitor implementation of linear phase FIR Decimator," Electron. Lett., vol. 66, no. 7-8, pp. 33943, July 1989. (E)

[1064] L. Ping and J.I. Sewell, "The twintor in band stop switched capacitor ladder filter realization," IEEE, Trans. Circuits Syst., vol. 36, no. 7, pp. 1041-4, July 1989. (D)

[1065] J. Cajika, "New findings in the theory of switched capacitor networks," Slabop. Obz, vol. 50, no. 7, pp. 331-3, July 1989. (A)

[1066] D. Watson, "Switched capacitor filter ICs," Electron. Prod. Des., vol. 10 , no. 7 , pp. $75-8$, July 1989 . (D)

[1067] J.S. Chang and Y.C. Tong, "A fully multiplexed pole shared switched capacitor filter bank," 8th Australian Conf. on microelectronics. Brisbane, pp. 127-31, July 1989. (D)

[1068] H.C. Kiong, M.B. Othman and M.A.M. Ali, "Implementation of switched capacitor IF filter using CIRCAD," 8th Australian Conf. on Microelectronic, Brisbane, pp. 122-6, July 1989. (D)

[1069] W.B. Michael, "Stray insensitive programmable switched capacitor filter," Proceeding of the 32nd Midwest Symposium on Circuits \& Systems, Champain, pp. 1189-92, vol. 2, August 1989. (D)

[1070] P. Choi and J.A. Connely, "A new network synthesis methodology for switched capacitor circuit design," Proc. of the 32nd Midwest Symp. on Circuits \& Systems, Champain, pp. 964-7, vol. 2, August 1989. (A)

[1071] K. Nakayama and M. Zhiquing, G. Yamamoto, "A method for minimize total capacitance in cascade realization of SC filters," Proc. of the 32nd Midwest Symp. on Circuits \& Systems, Champain, pp. 489-6, vol. 2, August 1989. (D)

[1072] S. Espejo-Meana and J.D. Martin-Gomez, "Application of piece wiselinear switched capacitor circuits for random number generator. Proc. of the 32nd Midwest Symp. on Circuits \& Systems, Champain, pp. 960-3, vol. 2, August 1989. (H)

[1073] H. Iwakura, "A consideration for stability problem of leapfrog type digital filters and SCFs,," Electron. Communi. Jpn. 3, Fundam Electron. Sci., vol. 72, no. 2, pp. 44-53, August 1989. (E)

[1074] M. Ishikawa and T. Yanagisawa, "Synthesis of balance SC integrator based on bilinear S-Z transformation," Electron. Communi. Jpn. 3 Fundam Electron. Sci., vol. 72, no. 1, pp. 48-54, August 1989. (B)

[1075] J.Z. Zhou, "Novel approach to reduced number of op amp in switched capacitor filter," Electron. Lett., vol. 25, no. 18, pp. 1259-60, August 1989. (D)

[1076] K. Nagraj, "A parasitic insensitivity area, efficient approach to realizing very large time constant in switched capacitor networks," IEEE Trans Circuits \& Syst., vol. 36, no. 9, pp. 1210-16, August 1989. (A)

[1077] A.E. Salama, E.M. Said and K.A. Albidwihy, "A parameters identification approach to fault diagnosis of switched capacitor circuit," European Conf. on Circuit theory and Design, Brighton, pp. 482-6, Sept. 1989. (A) 
[1078] H. Takase, Y. Horio and S. Nakamura, "Speech recognition algorithm based switched capacitor networks system," European Conf. on Circuit theory and Design, Brighton, pp. 492-6, Sept. 1989. (H)

[1079] L. Loth and E. Simonyi, "Examination of the eigen value of ideal SC circuit based on state equation approach," European Conf. on Circuit theory and Design, Brighton, pp. 482-6, Sept. 1989. (A)

[1080] A. Nacaroghu and M. Koksal, "Design of switched capacitor networks with minimum number of switches and capacitors," European Conf. on Circuit theory and Design, Brighton, pp. 497-501, Sept. 1989. (A)

[1081] L. Kunsagi and T. Fulop, "Unity gain buffer based switched capacitor biquads," European Conf. on Circuit theory and Design, Brighton, pp. 199-204, Sept. 1989. (D)

[1082] D.G. Haigh, "Switched capacitor of integrated circuits," European Conference on Circuit theory and Design, Brighton, pp. 195-8, Sept. 1989. (D)

[1083] A. Somogyi, T. Toth and L., E. Simonyi, "SCORE computer analysis of a switched capacitor networks containing resistors," European Conf. on Circuits theory and Design, Brighton, pp. 199-204, Sept. 1989. (A)

[1084] Wu Jie and Yang Shu-kong, "A novel high Q switched capacitor biquad realization with low sensitivity," Acta Electron. Sin, vol. 17, no. 5, pp. 47-51, Sept. 1989 (D)

[1085] I.Ya. Rankis, "Condition for the power takes off from a switched capacitor of a thyristorsed pulse regulator," Elektrichestro, no. 9, pp. 60-5, Sept. 1989. (H)

[1086] J.C. Vittal, J.E. Da. Franca, "Novel capacitance ratio independent switched capacitor digital analog converter," Electron. Lett., vol. 25, no. 20, pp. 1362-3, Sept. 1989. (G)

[1087] D. Watson, "Switched capacitor filter ICs II," Electron. Prod. Des., vol. 10 , no. 9 , pp. 87-8, Oct. 1989. (D)

[1088] S. Dasgupta, M.M. Mehendale, V.R. Sudrsan, R. Jaim and N. Subramanyan, "FDT-a design tool for switched capacitor filters," 1989 IEEE Int. Conf. on Computer-aided Design, Santa Clara, pp. 446-9, Nov. 1989. (D)

[1089] J. Tomberg and K. Kaski, "VLSI implementation of neural network based on switched capacitor structures," Nero-nines 89 Int. Workshop Neural Networks and their Application, France, Nov. 1989. (A)

[1090] J. Silva-Martin and E. Sanchez-Sinencio, "Strategic SC filters design on comparative study of various S to Z-mapping," IEEE Trans. Circuits Syst., vol. 36 , no. 11 , pp. $1465-72$, Nov. 1989. (D)

[1091] C. Psychalino and I. Heritantis, "SC bilinear integrators," IEEE Trans. Circuits and systems, vol. 36, no. 11, pp. 1493-41, Nov. 1989. (B)

[1092] Yuan Zhu-guo and Ma Sheng-qian, "A new method to analyze active SC networks with ideal and nonideal op. amps," Acta. Electron. Sin, vol. 17, no. 6, pp. 65-72, Nov. 1989. (A)

[1093] E.I. EI-Masry, "Novel switched capacitor integrator for high frequency application," IEE Proc. Circuit Device System, vol. 136, no. 5, pp. 263-7, Dec. 1989. (B)

[1094] S. Yoneda, T. Nakanishi and A. Ogihara, "Switched capacitor DFT and IDFT circuits," Int. J. Electron, vol. 67, no. 6, pp. 839-51, Dec. 1989. (E)

[1095] F. Ueno, T. Inoue, S. Araki and K. Sugitani, "A high accuracy switched 
capacitor pipeline analog to digital converter," Trans Inst. Electron. Inf. Communi. Engg. E, vol. E72, no. 12, pp. 1285-91, Dec. 1989. (G)

[1096] J. Willkins, "An adaptive SC speech analyzer with power determined frequency resolution," IEEE Trans Instru. Meas., vol. 38, no. 6, pp. 1149-6, Dec. 1989. (G)

[1097] K. Kato, K. Kubota and T. Takabe, "Variable switched capacitor band pass elimination filters and all pass networks with sensitivity," Electron. Communi. 3Fundam. Electron, vol. 72, no. 12, pp. 42-54, Dec. 1989. (D)

1990

[1098] A. Ogihara and S. Yoneda, "A 64 points switched capacitor discrete Fourier transform circuits on high speed inverse one," Trans. Inst. Electron. Inf. Communi. Engg. A, vol. J73A, no. 1, pp. 35-43, Jan. 1990. (H)

[1099] D.G. Haigh, C. Toumazou and A.K. Betts, "Switched-capacitor circuits and op amp," IN Book: GaAs technology and its Impact on Circuits \& Systems, pp. 313-56, Peter Peregrinus, 1990. (A)

[1100] U. Bernhardt, "Elementary noise sources of the scanning noise of SC integrators with continuous transmission path," Nachr. Elektronik, vol. 40, no. 2, pp. 51-5, 1990. (B)

[1101] J.C. Yu, C.V. Wu and S.S. Chang, "Realization of IIR/FIR and N-path filters using a novel switched capacitor techniques," IEEE Trans. Circuits Syst., vol. 37, no. 1, pp. 91-106, Jan. 1990. (E)

[1102] A. Handkiewicz and A. Rybarczyk, "On SC integrator alternative for high frequency switched capacitor filters," Rev. Hf., vol. 14, no. 7-8, pp. 211-23, 1990. (D)

[1103] U. Bernhardt and G. Schlauch, "Scanning noise of second order SC filters in cascaded structures," Nachrtech. Elektronik, vol. 40, no. 2, pp. 47-50, 1990. (D)

[1104] U. Bernhardt, "Calculation of sampling noise of SC integrators and SC filters at band limited, color primary noise," Nachrtech. Electronik, vol. 40, no. 51, pp. 173-7, 1990. (D)

[1105] P. Zbinden, "Automatic layout generation for SC circuits," Nitt. Agen., no. 51 , pp. $25-9,1990$. (A)

[1106] U. Bernhardt, "Sampling noise in SC filters of lattice form," Nachrtech. Electronik, vol. 40, no. 4, pp. 135-9, 1990. (D)

[1107] M. Naleez and J.J. Mulawka, "Generation of switched capacitor networks with morphological approach," Rozpr. Electrotech, vol. 34, no. 4, pp. 1101-12, Jan. 1990. (A)

[1108] M. Ishikawa and N. Fuji, "On the low pass and high pass transformation in SC," Electron. Communi. Jpn. 3Fundam. Electron. Sci., vol. 72, no. 5, pp. 3843, Jan. 1990. (D)

[1109] D. Asta, "Analysis of a hybrid analog/switched-capacitor phase locked loop," IEEE Trans. Circuits \& Syst., vol. 37, no. 2, pp. 183-97, Feb. 1990. (H)

[1110] F. Ueno, T. Inoue and I. Ooto, "Analysis and application of switched capacitor transformers formulation," Trans. Inst. Electron. Inf. Communi. Engg., vol. J73C-II, no. 2, pp. 63-73, Feb. 1990. (A) 
[1111] A. Ogihara, H. Hamano and S. Yoneda, "Switched capacitor delay system suitable for cascaded multistage," Int. J. Electron., vol. 68, no. 3, pp. 413-21, March 1990. (H)

[1112] U. Weder, "SCF, a gate-array switched capacitor filter design tool," J. Semi-custom, ICs., vol. 7, no. 3, pp. 14-19, March 1990. (D)

[1113] D. Biolek, "Fast analysis of switched capacitor filters by means of graph,' Slabop. Obz, vol. 51, no. 3, pp. 143-6, March 1990. (D)

[1114] T. Inoue, F. Ueno, S. Sonobe and T. Matsumoto, "Switched capacitor circuits analysis program SCNODAL and its," Electron. Communi. Jpn.3 Fundam. Electron. Sci., vol. 73, no. 3, pp. 38-49, March 1990. (A)

[1115] A. Hyogo and K. Sekine, "SC immittance simulation circuit using UGBs and their applications to filters," Electron. Communi. Jpn. 3Fundam. Electron. Sci., vol. 73, no. 3, pp. 50-6, March 1990. (D)

[1116] A. Rodriguez-Vazquez, Dominoguez R. Castrol, A. Rueda and J.L. Huertas, "Nonlinear switched capacitor neural networks for optimization problem," IEEE Trans. Circuits Syst., vol. 37, no. 3, pp. 384-98, March 1990. (H)

[1117] C. Toumazou, D.G. Haigh, S.J. Harrold, R. Steptoe and J.I. Sewell, "400MHz switched rate GaAs switched capacitor filters," Electron. Lett., vol. 26, no. 7, pp. 460-1, March 1990. (D)

[1118] Y. Takeda and C. Sato, "Switched capacitor filter block with clock frequencies," Electron. Communi. Jpn.3, Fundam. Electron. Sci., vol. 72, no. 4, pp. 31-41, April 1990. (D)

[1119] Sang Won Lee, Yong Seop Kim, Seong Won Kim, Wook Kang, Soo Won Kim and Duck Tin Kim, "A development of a software tools for automatic SCF design," J. Koreal Inst. Telemat. Electron, vol. 27, no. 4, pp. 137-40, April 1990. (D)

[1120] T. Adachi, J. Komo, M. Nishimoto and S. Suzki, "A integrated switched capacitor signal processing design systems," IEEE J. Solid State Circuits, vol. 25, no. 5, pp. 346-50, April 1990. (H)

[1121] M. Mittal and S.S. Jammur, "Analysıs of switched capacitor networks using Z-domain equivalent admittance," J. Inst. Electron. Telecommuni. Eng. A, vol. 35, no. 3, pp. 150-3, April 1990. (A)

[1122] N.B. Chkrabarti, B.C. Roy, N. Radhakrishanan and S. Mukhopadyaya, "Some applications of switched capacitor wave filters," J. Inst. Electron. Telecommuni. Engg., vol. 35, no. 3, pp. 141-9, April 1990. (D)

[1123] D.G. Haigh, J.T. Taylor and B. Singh, "Continuous-time and switched capacitor monolithic filters based circuit and charge simulation," IEE Proc. G. Circuits Devices Syst., vol. 137, no. 2, pp. 147-55, April 1990. (D)

[1124] T. Dostal and M. Sobeith, "Switched capacitor circuits without frequency response characteristic distortion," Slabop. Obz, vol. 51, no. 4, pp. 149-53, April 1990. (H)

[1125] Z Ma, K. Nakayama and G. Yamamoto, "A method to minimize total capacitance in cascaded realization of SC filters," Trans. Inst. Electron. Inf. Communi. Engg. A, vol. J73A, no. 4, pp. 759-68, April 1990. (D)

[1126] O. Hanegata and M. Tanaka, "Numerical analysis of switching transformation matrix for SC circuits," Electron. Communi. Jpn. 3 Fundam. Electron. Sci., vol. 73, no. 4, pp. 58-66, April 1990. (A) 
[1127] B. Ranche, "Switched capacitor filters in CMOS and BIMOS technology," Elektron. Entwickl., vol. 25, no. , pp. 8-9, April 1990. (D)

[1128] S. Fukai and H. Ishikawa, "Compensation techniques for SC type pretune circuits," Trans. Inst. Electron. Inf. Communi. Engg. A, vol. J73A, no. 4, pp. 775-82, April 1990. (A)

[1129] H. Matsumoto and Zheng Tang, "A buffer based switched capacitor integrator with reduced capacitance ratio," Trans. Inst. Electron. Inf. Communi. Engg. A, vol. J73A, no. 4, pp. 494-5, April 1990. (B)

[1130] S. Fukai and M. Ishimine, "A new type phase locked loop type pretune circuit of switched resistors," Trans Inst. Electron. Inf. Communi. Eng. A, vol. J73A, no. 4, pp. 915-16, April 1990. (H)

[1131] H. Iwakura, "Realization of leapfrog type switched capacitor using time share op. amp," Electron. Communi. Jpn.3 Fundam Electron. Sci., vol. 72, no. 8, pp. 91-9, April 1990. (D)

[1132] G. Fischer, "Switched capacitor low pass filter based on recursive running sun cells," Electron. Lett., vol. 26, no. 9, pp. 557-8, April 1990. (D)

[1133] P.J. Sust and W.J. Mcintyre, "Double sampling in switched-capacitor delta-sigma A/D converters," 1990 IEEE Int. Symp. on Circuits \& Systems, New Orleans, pp. 902-5, vol. 2, May 1990. (G)

[1134] D.G. Haigh, S.J. Harroid, K. Steptope, J.I. Sewell, R. Bayruns and C. Toumazou, "Design and testing of a GaAs switched capacitor filter," 1990 IEEE Int. symp. on circuits and systems, New Orleans, pp. 2825-8, vol. 4, May 1990. (D)

[1135] W.H. Ki and G.C. Temes, "Offset compensated switched capacitor integrator," 1990 IEEE Int. symp. on circuits and systems, New Orleans, pp. 28295, vol. 4, May 1990. (B)

[1136] L. Ping and J.I. Sewell, "Switched capacitor and active RC all pass filter," 1990 IEEE Int. symp. on circuits and systems, New Orleans, pp. 2833-6, May 1990. (D)

[1137] S.D. Willingham and K.M. Martin, "Finite gain compensated techniques for high-Q bandpass SC filters," 1990 IEEE Int. on circuits and systems, New Orleans, pp. 2821-4, May 1990. (D)

[1138] J.A. Hegt, "Signal flow graph on synthesis of stray insensitive switched capacitor filters," 1990 IEEE Int. symp. on circuits and systems, New Orleans, pp. 2177-80, vol. 2, May 1990. (D)

[1139] M. Negabam and D. Gajski, "Automatic synthesis of CMOS op amps for switched-capacitor compiler," 1990 IEEE Int. Symp. on Circuits \& Systems, New Orleans, pp. 2817-20, vol. 4, May 1990. (B)

[1140] U. Menzi and G.S. Moschytz, "Adaptive switched capacitor filters based on the LMS algorithm," 1990 IEEE Int. Symp. on Circuits \& Systems, New Orleans, pp. 2220-3, vol. 3, May 1990. (E)

[1141] A.K. Betts, D.G. Haigh and J.T. Taylor, "Design issues for a switched capacitor filter using GaAs technology," 1990 IEEE Int. Symp. on Circuits \& Systems, New Orleans, pp. 2216-19, vol. 3, May 1990. (D)

[1142] T. Ono, "A switched capacitor inductance simulation circuit realized with a current conveyor," 1990 IEEE Int. Symp. on Circuits \& Systems, New Orleans, pp. 2213-15, vol. 3, May 1990. (F) 
[1143] M. Nikodem, B,B. Battacharyya and S.M. Faruque, "Switched capacitor simulation of hopfield type neural networks," 1990 IEEE Int. Symp. on Circuits \& Systems, New Orleans, May 1990. (H)

[1144] Tsai-churg Yu, "The bilinear-mapping SC differentiators and the design of biquad and ladder filters," 1990 IEEE Int. Symp. on Circuits \& Systems, New Orleans, pp. 2189-92, vol. 3, May 1990. (D)

[1145] A.K. Betts and J.T. Taylor, "Evaluation and synthesis of ultra narrow band switched capacitor filters employing multirate technique," Int. Symp. on Circuits \& Systems, New Orleans, pp. 21997-200, vol. 3, May 1990. (D)

[1146] R.P. Martin, "Infinite impulse response switched capacitor interpolators with optimum implementation," 1990 IEEE Int. Symp. on Circuits \& Systems, New Orleans, pp. 2193-6, vol. 3, May 1990. (H)

[1147] D.G. Haigh and P.R. Radmore, "Some properties of continuous-time and switched capacitor based on current charge and voltage simulation," 1990 IEEE Int. Symp. on Circuits \& Systems, New Orleans, May 1990. (A)

[1148] M. Kaneko, "Frequency dependence boundedness properties for switched capacitor networks," 1990 IEEE Int. Symp. on Circuits \& Systems, New Orleans, pp. 2209-12, vol. 3, May 1990. (A)

[1149] B. Nowrouzian, "A new synthesis for the exact design of switched capacitor LDI all pass networks," 1990 IEEE Int. Symp. on Circuits \& Systems, New Orleans, pp. 2185-8, vol. 3, May 1990. (D)

[1150] A. Muratt and G.S. Moschytz, "Performance optimization of elliptic SC ladder filters using signal flow graph transformations," 1990 IEEE Int. Symp. on Circuits \& Systems, New Orleans, pp. 2205-8, vol. 3, May 1990. (D)

[1151] A. Puerta-notario, M. Sanz-postils, J.M. Mirosans and J.M. Miguel-lopez, "Exact analysis and sensitivity of nonideal switched capacitor networks through op.amp. asymptotic modelling," 1990 IEEE Int. Symp. on Circuits \& Systems, New Orleans, pp. 2201-4, vol. 3, May 1990. (A)

[1152] T. Onto, "A new switched-capacitor inductance circuit using unity gain buffers," 1990 IEEE Int. Symp. on Circuits \& Systems, New Orleans, pp. 21858, vol. 3, May 1990. (F)

[1153] A. Cichocki and R. Unbehauen, "Switched capacitor artificial neural networks for nonlinear optimization with constrains," 1990 IEEE Int. Symp. on Circuits \& Systems, New Orleans, pp. 2809-12, vol. 4, May 1990. (H)

[1154] J.J. Rijns and H. Wallings, "A CMOS class-AB transconductance amplifier for switched capacitor applications," Int. Symp. on Circuits \& Systems, Networks, USA IEEE, pp. 2801-4, vol. 4, May 1990. (B)

[1155] I-C. Jou and Y. Liu, "Programmable SC neural networks for solving nonlinear programming problems," 1990 IEEE Int. Symp. on Circuits \& Systems, New Orleans, pp. 2837-40, vol. 4, May 1990. (H)

[1156] A. Cichocki and R. Unbehauen, "Application of switched-capacitor self oscillating circuits to conversion of RLC parameters into a frequency or digital signal," Sen. Actuators, A. Phy., vol. A24, no. 2, pp. 124-37, May 1990. (H)

[1157] D. Biolek, "Computer analysis of time dependence in switched capacitor filters," Slabop. Obz, vol. 51, no. 51, pp. 221-4, May 1990. (D)

[1158] A. Dabrawaski and G.S. Moschytz, "Direct analysis of multiphase 
switched capacitor networks using signal flow graph," IEEE Trans. Circuits \& Syst., vol. 37, no. 5, pp. 594-607, May 1990. (A)

[1159] H. Quiting and W. Sawan, "Comments on design technology for improved capacitor area efficiency in switched capacitor biquads," IEEE Trans. Circuits \& Syst., vol. 37, no. 5, pp. 660-8, May 1990. (D)

[1160] K. Onda, Y. Matsuda, K. Abe and H. Amano, "Analysis of switched capacitor transformer with a large voltage transformer ratio and its applications," Electron. Communi. Jpn. 2. Electron., vol. 73, no. 1, pp. 854-96, June 1990. (H)

[1161] G. Ficher, "Analog FIR filters by switched capacitor technique," IEEE Trans. Circuits \& Syst., vol. 37, no. 6, pp. 808-14, June 1990. (E)

[1162] S.A. Kleinfelder, "A 4096 cell switched capacitor analog wave form storage integrator," IEEE Trans. Nucl. Sci., vol. 37, no. 3, pp. 1230-6, June 1990. (B)

[1163] R. Castello and G. Grassi, "A 500-nA sixth order band pass SC filter," IEEE J. Solid State Circuits, vol. 25, no. 3, pp. 6669-766, June 1990. (D)

[1164] W.H. ki and G.C. Temes, "Low-phase-error offset-compensated switched capacitor integrator," Electron. Lett., vol. 26, no. 13, pp. 951-9, June 1990. (B)

[1165] D. Bensoussan, "The use of switched capacitor filters in the design of raised cosine and duo binary filters," Proc. of the Int. Conf. on Communi. Control and Signal Processing, pp. 1157-63, vol. 1, July 1990. (D)

[1166] A. Rueda, and J.L. Huertas, "Triplicated modular redundancy for switched capacitor integrated circuits," Proc., of the Int. Conf. on Communi., Control and Signal Proc, New Trends in Turkey, pp. 1219-26, vol. 2, July 1990. (B)

[1167] Li. Bixia and Gu. Deren, "Symbolic sensitivity function of switched capacitor networks," Acta Electron. Sin., vol. 18, no. 4, pp. 102-7, July 1990. (A)

[1168] Lu Yue-shen and Yong-chao, "A new method for calculating the SC networks sensitivity group delay and group delay sensitivity," Acta Electron. Sin., vol. 18 , no. 4, pp. 102-7, July 1990 . (H)

[1169] X.F. Wania and D.A. John, "Programmable multiplexed switched capacitor filters," Electron. Lett., vol. 26, no. 14, pp. 1051-3, July 1990 (D)

[1170] P. Nehta, M. Darwish and N. Thomon, "Switched capacitor filters," IEEE Trans. Power Electron, vol. 5, no. 3, pp. 331-6, July 1990. (D)

[1171] J.F. Duque-carrillo and E. Sanchez-Sinencio, "Programmable switched capacitor bump equalizer architecture," IEEE J. Solid State Circuits., vol. 25, no. 4, pp. 1035-9, August 1990. (H)

[1172] K. Shibata, M. Emura and S. Yennda, "High power efficiency switched capacitor DC-DC converter," Bull. Univ. Osaka Perfect. A, vol. 38, no. 2, pp. 21-35, August 1990. (G)

[1173] M. Gupta and S.S. Jammur, "A new method for the analysis and design of canonical switched capacitor circuits," Microelectronic J, vol. 21, no. 4, pp. 920, August 1990. (A)

[1174] V.A. Pospelov, "Calculation of the frequency characteristic of active filters in the high frequency range," Telecommuni. Radio. Engg., vol. 44, no. 5, pp. 756, August 1990. (D)

[1175] B. Maundy and E.I. EI-Masry, "Switched-capacitor neural networks using 
pulse based arithmetic," Electron. Lett., vol. 26, no. 18, pp. 1495-6, August 1990. (H)

[1176] I. Oota, "Realization of a switched capacitor AC-DC converter with low output-voltage ripple and its design," Trans. Inst. Electron. Inf. Communi. Engg. E, vol. E73, no. 9, pp. 1434-41, Sept. 1990. (G)

[1177] R. Markell, "Response selection for SC filter chips," Electron. Prod. Des., vol. 11, no. 9, pp. 39-40, Sept. 1990. (D)

[1178] Y. Jyo, Y. Tausda and K. Nohara, "Analog median filter using switched capacitor circuits," Trans. Inst. Electron. Inf. Communi. Engg. C-II., vol. 11, no. 9, pp. 581-4, August 1990. (D)

[1179] C.R.W. Campbell, K.M. Reineck and F.M. Stephenson, "Noise prediction and measurement in Switched capacitor networks," Proceeding of the 33rd Midwest symp. on circuits and systems, Altra Canada, pp. 960-2, August 1990. (A)

[1180] Nian Shiong and Da Heng Yin, "Analysis of switched capacitor network in the frequency domain using continuous time N-port Equivalents," Proc. of the 33rd Midwest symp. on circuits and systems, Altra Canada, pp. 981-4, August 1990. (A)

[1181] F. Ueno, T. Inoue, I. Oota and H.B. Lian, "Design and realization of a switched capacitor AC-DC converter with a low output voltage ripple," Proc. of the 33rd Midwest symp. on circuits and systems, Altra Canada, pp. 1087-90, August 1990. (G)

[1182] T. Umeno, K. Takahashi, I. Oota, F. Ueno and T. Inoue, "New switched capacitor DC-DC converter with low input current ripple and its hybridation," Proc. of the 33rd Midwest symp. on circuits and systems, Altra Canada, pp. 109193, August 1990. (G)

[1183] R.E. Massara and A.T. Younis, "An efficient design method for optimal MOS integrated circuit switched capacitor LDI ladder filters," Proc. of the 33rd Midwest symp. on circuits and systems, Altra Canada, pp. 956-9, August 1990. (D)

[1184] D.A. Johns, A.S. Sedra and X.F. Wania, "Programmable multiplexed switched capacitor filters," Proc. of the 33rd Midwest symp. on circuits and systems, Altra Canada, pp. 976-6, August 1990. (D)

[1185] H. Matsumoto, Z. Tang and O. Ishizuka, "A buffer-based switched capacitor integrator with reduced capacitance ratio," Proc. of the 33rd Midwest symp. on circuits and systems, Altra Canada, pp. 719-20, vol. 2, August 1990. (D)

[1186] G. Fischer, "Efficient switched capacitor prefilter based on recursive running sum cells," Proc. of the 33rd Midwest symp. on circuits and systems, Altra Canada, pp. 977-980, vol. 2, August 1990. (D)

[1187] B. Nowrouzian, "A novel approach in the exact design of LDI symmetrical digital and switched capacitor filters," Proc. of the 33rd Midwest symp. on circuits and systems, Altra Canada, pp. 967-972, vol. 2, August 1990. (E)

[1188] D.D. Denton, M.A.S. afar, A.R.K. Ralston, C.N. Ho and S.G. He, "The long term reliability of a switched capacitor relative humidity sensor," Proc. of the 33rd Midwest symp. on circuits and systems, Altra Canada, pp. 854-857, August 1990. (H) 
[1189] M. Shibata, M. Emura and S. Yoneda, "Energy transmission of switched capacitor circuit and application to DC-DC converter," Trans. IEICE, vol. J73C, no. 9, pp. 489-97, Sept. 1990. (G)

[1190] Yong Seop Kim, Sang Won Lee, Yang Sung Joo, Soo Won Kim and Duck Jim Kim, "A study on the realization of cascaded biquads SCF," J. Korean Inst. Telemat. Electron., vol. 27, no. 9, pp. 126-31, Sept. 1990. (D)

[1191] Y. Takeda and C. Sato, "Second order switched-capacitor filter with two clock frequencies and its design," Electron. Communi Jpn. 3 Fundam Electron. Sci., vol. 72, no. 9, pp. 86-94, Sept. 1990. (D)

[1192] A. Handkiewicz, "Two dimensional SC filter design for picture detain enhancement," 5th European Signal Processing \& Conf. Barcaelona, pp. 587-90, vol. 1, Sept. 1990. (D)

[1193] A. Petraglia and S.K. Mitra, "Effect of coefficients inaccuracy in switched capacitor FIR filters," 5th European Signal Processing and Conf. Barcelona, pp. 537-40, vol. 1, Sept. 1990. (E)

[1194] Z. Ma, K. Nakayama and A. Yamamoto, "A method to minimize output noise in cascade SC filters," Trans. IEICE, vol. J73A, no. 10, pp. 1601-9, Oct. 1990. (D)

[1195] M. Biey, F. Montecchi and A. Premoli, "Switched capacitor cascaded biquad band pass filters from Mc per function," IEEE Trans. Circuits \& Syst., vol. 37, no. 10, pp. 1304-8, Oct. 1990. (D)

[1196] T. C-Yu, Wu. C-Y and S.C. Chang, "Realization of IIR/FIR and N-path filters using a novel switched capacitor technique," IEEE Trans circuits \& Syst., vol. 37, no. 10, pp. 1231-47, Oct. 1990. (E)

[1197] A. Cichocki, "A switched capacitor interface for capacitive sensors based on relaxation oscillator," IEEE Trans. Instrum. Meas., vol. 39, no. 5, pp. 747-9, Oct. 1990. (C)

[1198] J. Luck and J.G. Swanson, "First order switched capacitor, low pass filter implemented with GaAs insulated-gate FET switch," Electron. Lett., vol. 26, no. 22, pp. 1843-5, Oct. 1990. (D)

[1199] S. Nishimura, Y. Abe and S. Yoneda, "Low sensitivity realization of switched-capacitor high-Q band pass filters," Mem. Fac. Engg. Kobe Univ., no. 33, pp. 103-9, Nov. 1990. (D)

[1200] "Design and integration of channel filter for an SC transmultiplexer," AEU, vol. 44, no. 6, pp. 484-8, Nov. 1990 (D)

[1201] C.A. Gobert, S.K. Mitra and A. Petasglia, "Low pass band sensitivity switched capacitor filters using a parallel connection of two structurally lossless networks," 24th Asilomar conf. on signals, systems and computers, Pacific Grove, pp. 273-7, vol. 1, Nov. 1990. (D)

[1202] B. Maundy and E.I. EI-Masry, "A switched capacitor bidirectional associated memory," IEEE Trans. Circuits Syst., vol. 37, no. 12, pp. 1568-72, Dec. 1990. (H)

[1203] T. Curran and M. Collier, "Sensitivity properties of SC filters derive from LC ladder prototypes," IEEE Trans. Circuits \& Syst., vol. 37, no. 12, pp. 15446, Dec. 1990. (D)

[1204] J.S. Chang and Y.C. Tong, "A pole sharing technique for linear phase switched capacitor filter banks," IEEE Trans. Circuits Syst., vol. 37, no. 12, pp. 1544-6, Dec. 1990. (D) 
[1205] G.K. Butt and J.J.M. Geelen, "A fast settling CMOS operational amplifier for switched capacitor with 90-dB DC gain," IEEE J Solid State Circuits, vol. 25 , no. 6 , pp. $1379-84$, Dec. 1990. (B)

[1206] K. Svyoma, S.C. Fang and Y.P. Tsividis, "Simulation of mixed switched capacitor/digital networks with signal driven switch," IEEE J. Solid State circuits, vol. 25, no. 6, pp. 1403-13, Dec. 1990. (H)

[1207] S. Hirano and E. Hayahara, "Design of switched capacitor filter using negative impedance converters," Trans. IEICE, vol. J73A, no. 12, pp. 1944-7, Dec. 1990. (F)

[1208] Y. Anzai, K. Matsumoto, S. Yoneda and A. Ogihara, "Switched capacitor neural networks and their application to character recognition," Trans. Inst. Electron. Inf. Communi. Engg. E., vol. 73, no. 12, pp. 1932-9, Dec. 1990. (H)

1991

[1209] Jie Wu, "New switched capacitor universal biquadratic filter," Int. J. Electron, vol. 70, no. 1, pp. 135-8, Jan. 1991. (D)

[1210] P.J. Hurst, "Shifting the frequency response of switched capacitor filters by nonuniform sampling," IEEE Trans. Circuits Syst., vol. 38, no. 1, pp. 12-19, Jan. 1991. (D)

[1211] H. Baher, "Microelectronic switched capacitor filters," IEEE Circuits Devices Mag., vol. 7, no. 1, pp. 33-6, Jan. 1991. (D)

[1212] A. Mcleod, "Switched capacitor filter makes analogue accurate," New Electron., vol. 24, no. 11, pp. 10-18, Jan. 1991. (D)

[1213] T. Imai, H. Yokote and K. Watanable, "Speed controlled of brush less servo motor switched capacitor technique," IASTED Int. Conf. on High Technology in Power Industries, Calgary, Altra Canada Acta Press, pp. 246-9, 1991. (H)

[1214] S. Ogawa and K. Watanable, "A switched capacitor successive approximation analog to digital converters and its application to a capacitor meter," Bull. Res. Inst. Electron. Shizuoka, Univ., vol. 25, no. 7, pp. 131-42, 1991. (G)

[1215] C.S. Gargour, "Design of stable active-RC and switched capacitor filter having variable magnitude characteristic using unified approach," Comput. Electr. Engg., vol. 17, no. 1, pp. 1-21, 1991. (D)

[1216] M. Mehendate, "Switched capacitor filters synthesis system with built design for manufacturability," Proc. 4th CSI/IEEE Int. Symp. on VLSI Design New Delhi India, pp. 136-41, Jan. 1991. (D)

[1217] J. Zhong-Xuan, "Second order switched-capacitor building block and its application to the design of silicon efficient filters," IEE. Proc. G circuits, no. 1, pp. 9-16, Feb. 1991. (D)

[1218] S.S. Jammur and M. Mittal, "Synthesis of generalized switched capacitor networks," J. Inst. Electron. Telecommuni. Engg., vol. 37, no. 3, pp. 316-20, Feb. 1991. (A)

[1219] G.W. Robert and A.S. Sedra, "Synthesizing switched-current filter by transposing the SFG of switched-capacitor filter circuits," IEEE Trans. Circuits Syst., vol. 38, no. 3, pp. 337-40, March 1991. (D) 
[1220] T. Inoue, F. Ueno, S. Koga and K. Fuji, "Switched-capacitor electronic neuron circuits," Trans. Inst. Electron. Inf. Communi. Engg., vol. J74C-II, no. 3, pp. 201-4, March 1991. (H)

[1221] M. Negahban and D. Gajski, "Silicon compilation of switched-capacitor networks," EDAC Proc. of the European Design Automation Conf., Glasgow, pp. 164-8, March 1991. (H)

[1222] K. Shibata, M. Emura and S. Yoneda, "Energy transmission of switched capacitor circuit and application to DC-DC converter," Electron. Communi. Jpn. 2, vol. 74, no. 4, pp. 91-101, April 1991. (G)

[1223] V. Georgiev, "Design of multiple-loop four-phase switched capacitor networks an alternative approach," AEU, vol. 45, no. 3, pp. 193-6, May 1991. (D)

[1224] Y. Abe, K. Matsumoto, A. Ognihara and S. Yoneda, "Switched capacitor realization of two dimensional DFT," Int. J. Electron., vol. 70, no. 5, pp. 87589, May 1991. (A)

[1225] Ma. Zhiqiang and K. Nakayama, "A method to minimize sensitivity in cascade SC filters," Trans. Inst. Electron. Inf. Communi. Engg. A, vol. J74A, no. 5, pp. 766-4, May 1991. (D)

[1226] M. Mittal and S.S. Jammur, "Programmable frequency independent phase shifter of unity gain," Meas. Sci. Technol., vol. 2, no. 5, pp. 475-7, May 1991. (H)

[1227] S. Hirano and E. Hayahara, "Pre and post filtering offset on switched capacitor filters stop band attenuation," IEEE Trans. Circuits and Syst., vol. 38, no. 5, pp. 547-51, May 1991. (D)

[1228] A. Ogihara and S. Yoneda, "A 64-points switched capacitor discrete fourier transform circuits for high speed IDFT circuits," Electron. Communi. Jpn.

3. Fundam. Electron. Sci., vol. 73, no. 11, pp. 21-30, May 1991. (A)

[1229] T. Komazaki and K. Gunji, "A study on biquads SCF with one op.amp," Electron. Communi. Jpn. 3. Fundam Electron. (USA), vol. 73, no. 11, pp. 1-6, May 1991. (D)

[1230] J.J.F. Rijns and H. Wallings, "Stray insensitive switched capacitor sample delay hold buffers for video frequency applications," Electron. Lett., vol. 27, no. 8, pp. 639-401, May 1991. (H)

[1231] H. Shafeeu, A.K. Betts, J.T. Taylor, "Approaches to ultra-narrow band analogue ICs filter design using switched capacitor," IEE Colloquium on Advance in Analogue VLSI (Digest no. 099) London, IEE, pp. 1-9, May 1991. (D)

[1232] T.V. Kuklev and B.D. Donevsli, "Analysis of multi phase switched capacitor networks using node method," Radio Electron. Communi. Systems, vol. 33, no. 7, pp. 80-3, May 1991. (A)

[1233] Chen LI, Wu. Zhengguo, "A novel state space synthesis method for designing low sensitivity switched capacitor filters," Acta Electron. Sin., vol. 19, no. 3, pp. 118-20, May 1991. (D)

[1234] M. Nikodem and B.B. Battacharyya, "A novel method for the realizing switched capacitor transformers," Proceeding of the 34th Midwest symp. on circuits and systems, Monterey, pp. 562-5, vol. 2, May 1991. (A)

[1235] M. Nikodem and B.B. Battacharyya, "A novel method for synthesis of 
the switched capacitor high frequency voltage magnitude," Proc. of the 34th Midwest symp. on circuits and systems, Monterey, pp. 562-5, vol. 2, May 1991. (B)

[1236] A.E. Said, A. Khoder, E.A. Hosny and M.I. Sobhy, "A comprehensive synthesis of stray free switched capacitor," Proc. of the 34rd Midwest symp. on circuits and systems, Monterey, pp. 580-3, vol. 2, May 1991. (A)

[1237] M.C. Chain, "Simulation of mixed switched capacitor/Analog/digital circuits with arbitrary clock and signals," Proc. of the 34rd Midwest symp. on circuits and systems, Monterey, pp. 566-71, vol. 1, May 1991. (A)

[1238] A.C.M. De Queiroz and L.P. Caloba, "CAP-APC program for switched capacitor filter analysis in the Z-transform domain," Proc. of the Midwest symp. on circuits and systems, Monterey, pp. 134-7, vol. 1, May 1991. (A)

[1239] M. Delyado-Restituto, A. Rodriguez-Vazquez and J.L. Huertas, "1/f noise generation through a chaotic nonlinear switched capacitor circuits," Proc. of the Midwest symp. on circuits and systems, Monterey, pp. 52-5, vol. 1, May 1991. (A)

[1240] N. Kutsuzawa, Y. Nishio and S. Mori, "Chaotic phenomena in a switched capacitor phase locked loop," Proc. of the Midwest symp on circuits and systems, Monterey, pp. 56-9, vol. 1, May 1991. (H)

[1241] I.H. Ozgue and G. Fischer, "Switched capacitor lattice filters," Proc. of the 34th Midwest symp. on circuits and systems, Monterey, pp. 557-5, vol. 2, May 1991. (D)

[1242] S. Hirano and E. Hayahara, "Design of switched capacitor filters using bilinear transformation," Proc. of the 34rd Midwest symp. on circuits and systems, Monterey, pp. 572-5, vol. 2, May 1991. (D)

[1243] H. Baher and S. Zhuang, "Design of wide band switched capacitor filters with arbitrary and linear phase response," Proc. of the 34rd Midwest symp. on circuits and systems, Monterey, pp. 796-8, vol. 2, May 1991. (D)

[1244] D. Biolek, "Switched-capacitor filter design," Slabop. Obz., vol. 52, no. 6, pp. 162-71, June 1991. (D)

[1245] R.M. Fox, C.M: Stillo, and D.T. Ferris, "Criteria for low noise switched capacitor circuit design," Electron. Lett., vol. 27, no. 13, pp. 1203-5, June 1991. (A)

[1246] M.B. Moore, "A switched capacitor signal processing for capacitive microsensors," Microelectr. Conf. Enabling Technology, Barton, Act, Australia, pp. 21-4, June 1991. (H)

[1247] G.L. Wang and K. Watanable, "Current mode switched capacitor circuits synthesis by C-invariant dual transformation," 1991 IEEE Int. symp. on circuits and systems, Singapore, pp. 1553-6, vol. 3, June 1991. (A)

[1248] L. Toth, "Exact noise analysis of ideal switched capacitor networks," IEEE Int. symp. on circuits and systems, Singapore, pp. 1585-3, vol. 3, June 1991. (A)

[1249] F. Maloberti and A. Petraglia, "High frequency of simple switched capacitor transfer functions," 1991 IEEE Int. symp. on circuits and systems, Singapore, pp. 1669-72, June 1991. (A)

[1250] C.A. Makris and C. Toumazou, "Current mode compensation in switched capacitor filters," 1991 IEEE Int. symp. on circuits and systems, Singapore, pp. 1557-60, vol. 1, June 1991. (D) 
[1251] W.H. Ki and G.C. Temes, "Gain offset compensation in switched capacitor filters," 1991 IEEE Int. symp. on circuits and systems, Singapore, pp. 15614, vol. 1, June 1991. (A)

[1252] D. Vasquer, A. Rueda and J.L. Huertas, "A practical implementation of fault tolerant switched capacitor circuits," 1991 IEEE Int. symp. on circuits and systems, Singapore, pp. 1565-3, June 1991. (A)

[1253] L. Ping, R.C.J. Taylor, R.K. Henderson and J.I. Sewell, "Design of switched capacitor filter for voice band signals," 1991 IEEE Int. symp. on circuits and systems, Singapore, pp. 1573-6, vol. 3, June 1991. (D)

[1254] J.T. Taylor, J. Luck, J.G. Swanson and D.G. Haigh, "Realization of high frequency GaAs switched capacitor filters using insulated gate switches," 1991 IEEE Int. symp. on circuits and systems, Singapore, pp. 1661-4, vol. 3, June 1991. (D)

[1255] J.J.F. Rijins and H. Wallinga, "Stray insensitivity sample-delay-hold buffer for high frequency switched capacitor filters," 1991 IEEE Int. symp. on circuits and systems, Singapore, pp. 1665-8, vol. 3, June 1991. (D)

[1256] A. Baschirotto, "IIR doubled sampled switched capacitor building blocks for high frequency decimators," 1991 IEEE Int. on circuits and systems, Singapore, pp. 1673-6, vol. 3, June 1991. (E)

[1257] Y. Hirata, T. Kikui, N. Takahashi and T. Takebo, "High frequency switched capacitor FIR filters using parallel cyclic type circuits," 1991 IEEE Int. symp. on circuits and systems, Singapore, pp. 1677-80, vol. 3, June 1991. (E)

[1258] A. Petraglia and S.K. Mitra, "Digitally programmable switched capacitor equalizers," 1991 IEEE Int. on circuits and systems, Singapore, pp. 1681-4, vol. 3, June 1991. (H)

[1259] U.F. Dias and J.E. Franca, "Programmable FIR switched capacitor decimators," 1991 IEEE Int. symp. on circuits and systems, Singapore, pp. 1685-8, vol. 3, June 1991. (H)

[1260] S. Eriksson, "Realization of switched capacitor delay lines and Hillbert transformers," Electron. Lett., vol. 27, no. 4, pp. 126-4, July 1991. (A)

[1261] J.E. Da. Franca, "Systematic method for the design of multiplier switched capacitor FIR decimator circuits," IEE. Proc. G, Circuits Devices Syst., vol. 138, no. 3, pp. 307-14, July 1991. (H)

[1262] R. Castello and L. Tomasine, "1.5-V high performance SC filters in BIMOS technology," IEEE J. Solid State Circuits," vol. 26, no. 7, pp. 930-6, July 1991. (D)

[1263] G.S. Moschytz and W. Guggenbuhl, "New design techniques and application for analog and switched capacitor VLSI circuits," 6th Mediteranean Electrotechnical conf. Proc. (New York IEEE USA), pp. 2-3, vol. 1, July 1991. (A)

[1264] J.L. Luck, J.T. Taylor, J.G. Swason and D.G. Haigh, "High frequency GaAs switched capacitor filter implemented with GaAs insulated gate FET switch," Electron. Lett., vol. 27, no. 18, pp. 1619-20, August 1991. (D)

[1265] H. Sira-Ramirer, M.T. Prada-Rizzo and P. Lischinsky-Arenas, "Dynamical variable structure systems approach to switched capacitor circuit models," Int. J. Syst. Sci., vol. 22, no. 8, pp. 1477-94, August 1991. (A)

[1266] A. Limperis and I. Haritants, "Development and design of wave SC filters," Int. J. Circuit Theory \& Appl., vol. 19, no. 4, pp. 321-39, August 1991. (D) 
[1267] A.K. Betts, H. Shafeeu and J.T. Taylor, "Amplifier gain insensitive SC integrator with sample-sample correction of both gain and phase errors for singlepath and multi-path circuits," Electron. Lett., vol. 27, no. 17, pp. 321-39, August 1991. (B)

[1268] D.G. Haigh, C. Toumazou, S.J. Harrold, K. Stepoe, J.I. Sewell and R. Bayruns, "Design optimization and testing of a GaAs switched capacitor filter," IEEE Trans. Circuits \& Syst., vol. 38, no. 8, pp. 825-37, August 1991. (D)

[1269] Min Kyu Song, Yong Man Lee, Ki Jung Ahu and Won Chan Kim, "A study on the new design methodology for switched capacitor filters," J. Korean Inst. Telemat. Electron., vol. 28, no. 8, pp. 48-56, August 1991. (D)

[1270] Z. Czarnul, G.C. Temes and A.G. Yesiyert, "Pseudo N-path switched capacitor filters without of band noise peaks.," Electron. Lett., vol. 27, no. 13, pp. 1137-9, Sept. 1991. (D)

[1271] M.F. Fahmy, A. El-Worclancy, G.A. Raheem and F.A. Fattah, "Low sensitivity SC realization of brue and C-type reactance sections," Int. J. Circuit Theory Appl., vol. 19, no. 5, pp. 459-70, Sept. 1991. (H)

[1272] A. Petraglia and S.K. Mitra, "Effects of coefficient inaccuracy in the switched capacitor transversal filters," IEEE J. Solid State Circuits, vol. 26, no. 10, pp. 977-83, Sept. 1991. (D)

[1273] T. Ono, "A synthesis of switched capacitor inductance simulation circuit using voltage follower," Trans. Inst. Electron. Inf. Communi. Eng. A, vol. J74A, no. 9, pp. 1385-92, Sept. 1991. (F)

[1274] A. Handkiewicz, "Two dimensional switched capacitor filter design system for real time image processing," IEEE Trans. Circuits Syst. Video Technol., vol. 1, no. 3, pp. 241-6, Sept. 1991. (D)

[1275] O.V. De. Avilezfilho and J.A.S. Dias, "Linearization of polynomial functions in dual-slope analog to digital converters using switched capacitor circuits," Microelectron. J., vol. 22, no. 5-6, pp. 56-63, Sept. 1991. (G)

[1276] R.E. Vallee and E.I. EI-Masry, "Novel CMOS op-amp. design technique for high frequency switched capacitor applications," IEE Proc. G. Circuits Devices Syst., vol. 138, no. 5, pp. 623-6, Oct. 1991. (B)

[1277] J.J.F. Rijns, "Comments on realization of switched capacitor delay and Hilberts transformation and reply," Electron. Lett., vol. 27, no. 22, pp. 2042-3, Oct. 1991. (A)

[1278] S. Ogawa and K. Watanable, "Clock feed through compensated switched capacitor circuits," Electron. Lett., vol. 27, no. 22, pp. 2045-6, Oct. 1991. (A)

[1279] J.C. Nallatemby, M. Bridier, M. Pregent and J. Obregon, "Accurate simulation of nonlinear switched capacitors and sampled circuits by harmonic balance and related technique," Electron. Lett., vol. 27, no. 25, pp. 2764-7, Oct. 1991. (A)

[1280] A. Rodriguez-Vazaquez, M. Delgado, S. Espejo and J.L. Huertas, "Switched capacitor broad band noise generator for CMOS VLSI," Electron. Lett., vol. 27, no. 11, pp. 1913-15, Oct. 1991. (H)

[1281] K. Nohara, Y. Jyo and S. Kajiwara, "Switched capacitor multiplier and its applications," Trans. Inst. Electron. Communi. Engg., vol. J74C-II, no. 10, pp. 735-7, Oct. 1991. (H) 
[1282] H. Ishiuz, K. Takahashi, T. Umeno and Y. Sagara, "A New ripple and noise DC-DC converter developed on the basis of a switched capacitor transformer," Sumitomo Search, no. 47, pp. 95-102, Oct. 1991. (G)

[1283] T. Umeno, Y. Sagara and K. Takahashi, "A new method for generating low ripple converters an approach from switched capacitor circuits," Sumitomo. Search., no. 47, pp. 150-9, Oct. 1991. (G)

[1284] W. Wolski, "Topological analysis and Synthesis of SC biquads," Arch. Elektrotech., vol. 38, no. 1-4, pp. 393-404, 1989. (D)

[1285] H. Shafeeu, A.K. Betts and J.T. Taylor, "Novel amplifier gain insensitive switched capacitor integrator with same sample correction properties," Electron. Lett., vol. 27, no. 24, pp. 2277-9, Nov. 1991. (B)

[1286] J. Goette and A. Kaelin, "An automatic noise computations for general integrator based switched capacitor filters," IEEE Trans. Circuits Syst., vol. 38, no. 11, pp. 1249-54, Nov. 1991. (D)

[1287] A. Kaelin, J. Goette, W. Guggenbuhl and G.S. Moschytz, "A novel capacitance assignment procedure for the design of sensitivity and noise-optimized SC filters," IEEE Trans. Circuits Syst., vol. 38, no. 11, pp. 1255-60, Nov. 1991. (D)

[1288] J.J.F. Rijns and H. Wallina, "Spectral analysis of double sampling switched capacitor filters," IEEE Trans. Circuits Syst., vol. 38, no. 11, pp. 126919, Nov. 1991. (D)

[1289] A. Petraglia and S.K. Mitra, "Switched capacitor equalizers with digitally programmable tuning characteristics," IEEE Trans. Circuits Syst., vol. 38, no. 11, pp. 1322-31, Nov. 1991. (H)

[1290] J.R. Jordan, K.W. Peter and D. Renshaw, "A capacitance ratio to frequency ratio converter using switched capacitor techniques," Sen. Actuators A, Phys., vol. A29, no. 2, pp. 133-9, Nov. 1991. (G)

[1291] P.J. Hurst and J.E.C. Brown, "FIR switched capacitor filters for the delta sigma modulator D/A interface," IEEE Trans. Circuits Syst., vol. 38, no. 11, pp. 1391-7, Nov. 1991. (G)

[1292] M. Cheng and T.C. Huang, "Switched capacitor pipe lined logarithmic A/D and D/A converters," IEE Proc. G. Circuits Devices Syst., vol. 138, no. 6, pp. 714-16, Dec. 1991. (G)

[1293] C. Psychalinos and I. Haritantis, "Switched capacitor circuit synthesis using voltage inversion switches," IEE Proc. G. Circuits Devices Syst., vol. 138, no. 6, pp. 703-13, Dec. 1991. (A)

[1294] J.E. Da. Franca, "Switched capacitor polyphase decimating circuits with reduced capacitance spread," Electron. Lett., vol. 27, no. 25, pp. 2356-7, Dec. 1991. (A)

[1295] Daheng Yin, Zunqiao Zhang and Jiwen Li, “A simple switched capacitor based capacitance to frequency converters," Analog Integr. Circuits Signal Process., vol. 1, no. 4, pp. 353-61, Dec. 1991. (G)

[1296] T. Miyazaki, S.T. Lin, C. Miwamitale and T. Takeshi, "Ultra low frequency oscillator with switched capacitor," Trans. Electron. Inf. Communi. Engg. C-II, vol. J74C-II, no. 12, pp. 773-9, Dec. 1991. (C)

[1297] Nian Shiong Jan and Da-Heng Yin, "Analysis and design of op-amp. in 
switched capacitor filters," Model Simul. Control. A, vol. 40, no. 3, pp. 9-14, 1991. (D)

[1298] L. Divis, "Determining the sensitivity of functions of the SC circuit by means of the faddejev algorithms," Slabop. obz., vol. 52, no. 11, pp. 11-12, 1991. (A)

[1299] D. Biolek, "Z-domain groups of switched capacitor building blocks," Elektrotech. Cas, vol. 42, no. 11-12, pp. 562-72, 1991. (A)

[1300] D. Biolek, "Design of SC filters with unit amplifier with the aid of bilinear transform," Slabop. obz., vol. 52, no. 11, pp. 270-271, 1991. (D)

[1301] A. Kaelin and G.S. Moschytz, "A new comprehensive procedure for the ladder exact design of canonic LDI type SC filters," J. Circuits Syst. Comput., vol. 1, no. 4, pp. 417-441, Dec. 1991. (A)

1992

[1302] R.P. Martins and J.E. Da. Franca, "Optimum multistage multirate switched capacitor architecture for highly selective interface filtering," Electron. Lett., vol. 28, no. 1, pp. 72-5, Jan. 1992. (D)

[1303] M.F. Fahmy, M.M. Doss and F. Abdel-Fattah, "Low sensitivity SC simulation of reactance E-type zero producing sector," IEEE Trans. Circuits Syst., vol. 39, no. 1, pp. 59-63, Jan. 1992. (G)

[1304] M.J. Long, "Systematic method for design of switched capacitor filters," Electron. Lett., vol. 28, no. 3, pp. 59-63, Jan. 1992. (D)

[1305] Y. Hirata, N. Takahashi, K. Kato, T. Kikui and T. Takebe, "A new FIR switched capacitor circuits for high frequencies with low power consumption," Trans. Inst. Electron. Communi. Engg. A, vol. J78A, no. 1, pp. 27-38, Jan. 1992. (H)

[1306] A. Robertini and W. Guggenbuhl, "Errors in SC circuits derived from linearly modeled amplifiers and switches," IEEE Trans. Circuits Syst., vol. 39, no. 2, pp. 93-101, Feb. 1992. (A)

[1307] H. Baher and Songxin Zhuang, "Switched capacitor band pass filters with simultaneous amplitude selectivity pass band linearity," Analog Integr. Circuits Signal Process, vol. 1, no. 1, pp. 5-17, Feb. 1992. (D)

[1308] R.P. Martine, "Novel second order switched capacitor interpolator," Electron. Lett., vol. 28, no. 4, pp. 348-50, Feb. 1992. (A)

[1309] V.F. Dias, G. Palmisano and F. Maloberti, "Fundamental limition of switched capacitor sigma delta modulator," IEE Proc. G. Circuits Devices Syst., vol. 41, no. 1, pp. 81-86, Feb. 1992. (H)

[1310] M. Yamada, T. Takebayashi, S. Notoyama and K. Watanable, "A switched capacitor interface for capacitance pressure sensor," IEEE Trans. Instru. Meas., vol. 41, no. 1, pp. 81-86, Feb. 1992. (H)

[1311] M. Kameko and H. Kunieda, "An optimum placement of capacitors in the layout of switched capacitor networks," IEICE Trans. Fundam Electron. Communi. Computer Sci., vol. E75A, no. 2, pp. 215-223, Feb. 1992. (A)

[1312] V.S. Subramanicm and K.M.M. Prabhu, "Novel phase meter using narrow pulse switched capacitor phase shifter," Electrn. Lett., vol. 28, no. 6, pp. 589591, March 1992. (H) 
[1313] M.G. Vitkov, "A discrete filter employing switched capacitor with short pulse response," Telecommuni. Radio Engg., vol. 46, no. 3, pp. 83-6, March 1992. (D)

[1314] J. Porte, "A discrete optimization method of cascaded switched capacitor filters," Ann. Telecommuni., vol. 47, no. 3-4, pp. 153-158, March 1992. (D)

[1315] A.T. Younis and R.E. Massara, "Automated synthesis of switched capacitor ladder filters within an analogue silicon compilation environment," IEE Proc. G. Circuits Devices Syst., vol. 139, no. 2, pp. 249-55, April 1992. (H)

[1316] A.E. Salama and F.Z. Amer, "Fault dictionary approach for fault diagnosis of switched capacitor circuits," Int. J. Electron., vol. 72, no. 4, pp. 577591, April 1992. (A)

[1317] A. Baschirotto, R. Castello and F. Montecchi, "IIR double sampled switched capacitor decimator for high frequency application," IEEE Trans. Circuits Syst., vol. 39, no. 4, pp. 300-304, April 1992. (H)

[1318] M. Deligado Restituto, A. Rodriguez Vasquez, S. Espejo and J.L. Huertas, "A chaotic circuits for $1 / \mathrm{f}$ noise generators," IEEE Trans. Circuits Syst. 1 Fundam Electron., vol. 39, no. 4, pp. 325-328, April 1992. (H)

[1319] G. Toffolo, P. Yick and N.M. White, "Development of a CMOS switched capacitor instrumentation amplifiers," IEE Colloquium on ASICs for measurement systems (Digest no. 85) London, IEE, pp. 2/1, April 1992. (B)

[1320] S. Hirano and E. Hayahara, "A design of simple structure switched capacitor filter based on the concept of the bilinear transformation," Analog Integr. Circuits Signal Processing, vol. 2, no. 2, pp. 131-8, April 1992. (D)

[1321] S. Nakamura, Y. Horio and H. Takase, "A switched capacitor preprocessor for speech recognition," Analog integra. Circuits Signal process, vol. 2, no. 2, pp. 79-94, April 1992. (H)

[1322] M. Fawzy Wagely, "An 8 bit parasitic-insensitive switched capacitor A/ D converter," Analog Integra. Circuits Signal Process, vol. 2, no. 2, pp. 157-63, April 1992. (G)

[1323] D. Biolek, "A physical meaning of switched capacitor system functions," Slabop. obz, vol. 53, no. 1-2, pp. 12-16, 1992. (H)

[1324] S.V. Cheong, S.H. Chung and A. Ioinovici, "Development of power electronics converters based on switched capacitor circuits," 92 IEEE Int. Symp. on circuits and systems, San Diego, pp. 1907-4, May 1992. (G)

[1325] P.J. Hurst and K.K. Dyer, "An Improved double sampling scheme for switched capacitor delta sigma modulators," 92 IEEE Int. Symp. on circuits and systems, San Diego, pp. 1179-82, vol. 3, May 1992. (H)

[1326] S. Ogawa and K. Watanable, "Clock feed through compensated switched capacitor circuits," 1992 IEEE Int. symp. on circuits \& systems San Diego, pp. 1195-8, vol. 3, May 1992. (A)

[1327] C. Ouslis, M. Snelgrove and A.S. Sedra, "Multirate switched capacitor filter design with aggressive sampling ratio filters," 92 Int. symp. on circuits \& systems, San Diego, pp. 1183-6, vol. 3, May 1992. (D)

[1328] W.H. Ki and G.C. Temes, "Area efficient gain and offset compensated very large time constant switched capacitor biquads," 1992 Int. symp. on circuits \& systems, San Diego, pp. 1187-90, vol. 3, May 1992. (D)

[1329] T. Ono, "A switched capacitor inductance simulation circuit realized with 
current convener," 92 Int. symp. on circuits \& systems, San Diego, pp. 1191-4, vol. 3, May 1992. (F)

[1330] Y. Hirata, K. Kato and N. Takanashi, "High frequency switched capacitor IIR filter using parallel cyclic type," 92 Int. symp. on circuits \& systems, San Diego, pp. 1199-202, vol. 3, May 1992. (D)

[1331] Z. Ma, K. Nakayama and G. Yamamaoto, "Optimum pairing and ordering condition for simulation reduction in total capacitance sensitivity and output noise cascade switched capacitor filter," 92 Int. symp. on circuits \& systems, San Diego, pp. 1203-6, vol. 3, May 1992. (D)

[1332] M.A. Tan, "Biquadratic transconductance switched capacitor filter," 92 Int. symp. on circuits \& systems, San Diego, pp. 1211-14, vol. 3, May 1992. (D)

[1333] J.C.M. Bermudez, M.C. Schneider and C.G. Mantoro, "Linearity of switched capacitor filter employing nonlinear capacitance," 92 Int. symp. on circuits \& systems, San Diego, pp. 1211-14, vol. 3, May 1992. (D)

[1334] Chung Yuwu, Shou Yuan, Huang Tsai, and Chung Yu Yuan Shien, "Non recursive switched capacitor decimator and interpolator circuits," 92 Int. symp. on circuits \& systems, San Diego, pp. 1213-18, vol. 3, May 1992. (H)

[1335] T. Dostal and J. Mikula, "Parametric S-Z transformation and its application of four SC inductors," Electron. Lett., vol. 28, no. 11, pp. 1028-1029, May 1992. (F)

[1336] K. Nakayama and G. Yamamoto, Zhi Quiang Ma, "A method to minimize sensitivity in cascade SC filters," Electron. Communi. Jpn., 3Fundam Electron. Sci., vol. 74, no. 12, pp. 86-96, May 1992. (D)

[1337] B. Raut, B.B. Bhattacharyya and S.M. Faruque, "Systolic array architecture implementation of parasitic insensitive switched capacitor filters," IEE Proc. G. Circuits Devices Syst., vol. 139, no. 3, pp. 384-394, June 1992. (D)

[1338] P.V. Anand Mohan, "Comments on New monolithic Switched capacitor Differentiators with good noise rejection," IEEE J. Solid State Circuits, vol. 27, no. 6 , pp. 951, June 1992. (H)

[1339] T. Dostal, "The P-Z transformation for designing circuits containing switched capacitor," Radio Electron. Communi. Syst., vol. 34, no. 6, pp. 29-32, July 1992. (A)

[1340] S.T. Farchy, T.G. Couymdijiev and E.D. Gadzhera, "Computer analysis of switched capacitor circuits containing op-amp," Radio Electron. Communi. Syst., vol. 34, no. 6, pp. 33-40, July 1992. (A)

[1341] Luo. Xianjue and Que. Guanyuan, "A diagnosis algorithm of fault dictionary in switched capacitor networks," Acta. Electron. Sin, vol. 19, no. 4, pp. 17-25, July 1992. (A)

[1342] A.A. Beex and S.M. Faruque, "Analysis of clock jitter in switched capacitor systems," IEEE Trans. Circuits \& systems I. Fundam theory Appl., vol. 39, no. 7, pp. 506-19, July 1992. (A)

[1343] K. Nakayaham, G. Yammoto and Z. Ma, "A method to minimize output noise in cascade SC filters," Electron. Communi. Jpn. 3, Fundam Electron. Sci., vol. 74, no. 8, pp. 11-21, August 1992. (D)

[1344] H. Matsumoto, Z. Tang and O. Ishizuka, "Capacitance-ratio-reduced simple switched capacitor integrators based on unity gain buffer configuration," Bull, Fac. Engg. Miyazaki, Univ., no. 38, pp. 221-4, August 1992. (B) 
[1345] Y. Hirata, N. Takahashi, K. Kato, and T. Kikui, "New FIR switched capacitor circuit for high frequencies with compensation $\mathrm{C}$ parallel cyclic type circuits," Electron. Communi. Jpn. 3Fundam Electron. Sci., vol. 75, no. 8, pp. 64-78, August 1992. (E)

[1346] H. Matsumoto, Z. Tang and O. Ishizuka, "Buffer based switched capacitor circuits with offset and unity gain error compensation," Bull. Fac. Engg. Miyuzaki Univ., no. 38, pp. 225-30, August 1992. (A)

[1347] M. Matsuki and S. Mori, "Oscillation in negative resistance oscillatory circuit containing periodically operating switches," Trans. Inst. Electron. Inf. Communi. Engg. A, vol. J75A, no. 9, pp. 1465-75, Sept. 1992. (H)

[1348] R.P. Martins, J.E. Da. Franca, and F. Maloberti, "An experimental 1.8um CMOS antialiasing switched capacitor decimator with output sampling frequency," ESSCIRC'91, 17th European solid state circuits conf. Proc., pp. 13-16, Sept. 1991. (H)

[1349] Trinh Ba Tung, "Computer aided analysis of switched capacitor networks," Meres Autom, vol. 40, no. 5, pp. 277-81, Sept. 1992. (A)

[1350] T. Kaneko, Y. Akazawa and M. Nagatani, "Switched capacitor and active RC filter layout using a parameterizable generator," IEICE Trans Fundam Electron. Communi. Comput. Sci., vol. E75A, no. 10, pp. 1301-5, Oct. 1992. (D)

[1351] D. Eddows, "Evolution of biquads and LC ladder implementations for switched capacitor filter design," IEE twelfth saraga colloquium on digital and analogue filters and filtering system, pp. 10/1-13, Nov. 1992. (D)

[1352] T. Chanak, R. Chanda and K. Singhal, "Switched capacitor simulation model for chips verification," IEEE Trans Comput. aided Des. Integr. Circuits syst., vol. 11, no. 11, pp. 1363-1367, Nov. 1992. (A)

[1353] C.B. Uminger, "Switched capacitor networks for focal plane processing systems," IEEE Trans Circuits Syst. Video Technol., vol. 2, no. 4, pp. 392-400, Dec. 1992. (H)

[1354] V.F. Dias, G. Palmisano and F. Malobreti, "Noise in mixed continuous time switched capacitor sigma-delta modulator," IEE Proc. G, Circuits devices Systems, vol. 139 , no. 6 , pp. 680-4, Dec. 1992. (H)

[1355] T. Doatal, "Switched capacitor circuits," Radio Electron. Communi. Syst., vol. 35, no. 1, pp. 11-23, 1992. (A)

[1356] M. Abo-Zahhad, "Switched capacitor circuits with reduced influence of parasitic capacitances switch resistance, and amplifier nonlinearity," Period Polytech., vol. 30, no. 1, pp. 19-37, 1992. (B)

[1357] Y. Hirata, K. Kato, N. Takahashi, and T. Takebe, "High frequency IIR switched capacitor using parallel cyclic type circuit with low power consumption," Trans. Inst. Electron. Inf. Communi. Engg. A, vol. J75A, no. 12, pp. 1800-10, Dec. 1992. (E)

\section{SUPPLEMENTARY LIST OF REFERENCES FOR THE PERIOD BEFORE MAY 1981}

[1] A.K. Bandyopadhyaya, "Equivalent circuit of a switched capacitor resistor, [for MOS active filter," Proc. IEEE, vol. 68, no. 1, pp. 178-179, Jan. 1980. (D) 
[2] E. Hokenek and G.S. Moschytz, "Analysis of general switched capacitor networks using indefinite admittance matrix," IEE Proc. G, vol. 127, no. 1, pp. 21-33, Jan. 1980. (A)

[3] J.A. Nossek, "Improved circuit for switched capacitor simulation of an inductor," Electron. Lett., vol. 16, no. 13, pp. 141-2, Feb. 1980. (F)

[4] L. Stenberg, "Switched capacitor filters," Elektronik, no. 14, pp. 10-13, April 1980. (D)

[5] T. Inoue and F. Ueno, "New bilinear switched capacitor immittance converter," Electron. Lett., vol. 16, no. 8, pp. 285-6, April 1980. (F)

[6] S.C. Fan, R. Gregorian, G.C. Temes and M. Zomorodi, "Switched capacitor filter using unity gain buffer," Proc. of the Int. symp. on circuits and syst., Houston, pp. 334-7, April 1980. (D)

[7] G. Sphlinger, "The influence of operational amplifier in switched capacitor filters," AEU, vol. 35, no. 9, pp. 342-2, June 1980. (D)

[8] G. Martinethi and M. Salerno, "Synthesis containing switched capacitor resonator," Altra, Frequency, vol. 49, no. 3, pp. 218-23, June 1980. (A)

[9] D. Cormier, "Programmable switched capacitor filter ICs cut component count in many filter type," EDN, vol. 31, no. 13, pp. 75-76, June 1980. (D)

[10] Lee Mun Soo, Lee Song Seol and Young in Eung, "A study on the design of active switched capacitor filter using bilinear Z-transform," J. Korea Inst. Electron. Engg., vol. 17, no. 4, pp. 23-30, August 1980. (D)

[11] J.J. Mulawka and G. Ghausim, "Second order functions realization with switched capacitor network and unity gain amplifier," IEE Proc. G, vol. 127, no. 187-90, August 1980. (A)

[12] T. Inoue and F. Ueno, "A new switched capacitor inductance simulation circuit using op amp," Trans IECE, vol. E63, no. 9, pp. 603, August 1980. (F)

[13] J. Mikula, "Inductors with switched capacitor," Slaboproudy Obz, vol. 41, no. 9 , pp. 456, Sept. 1980. (F)

[14] J.J. Mulawka, "By-inspection analysis of switched capacitor networks," Int. J Electron., vol. 49, no. 5, pp. 359-73, Oct. 1980. (A)

[15] E. Wehrhahn, "Evaluation of transfer functions of ideal switched capacitor networks in Z-domain using standard linear symbolic or semi-symbolic network analysis programs," Electron. Lett., vol. 16, no. 21, pp. 801-4, Oct. 1980. (A)

[16] D. Hampel and J.L. Bradshaw, "Application of monolithic CMOS switched capacitor filters and amplifiers for signal processing," IEEE Trans Communication, vol. 28 , no. 10 , pp. $1828-32$, Oct. 1980 . (D)

[17] M. Arnoldt, "Application of band pass filters with switched capacitor," Elektronik, vol. 29 , no. 21 , pp. 83-7, Oct. 1980. (D)

[18] M.K. Li, "Pseudo power in switched capacitor filters," Electron. Lett., vol. 16 , no. 21 , pp. $813-14$, Oct. 1980 . (D)

[19] H. Weinrichter, "Switched capacitor filter, a new way for filter integration," Electrotech. \& maschinenban, vol. 97, no. 21, pp. 417-22, Oct. 1980. (A)

[20] J. Reinecker, "Designing of switched capacitor filters," Elektronik, vol. 29, no. 21 , pp. $83-7$, Oct. 1980 . (D)

[21] K. Martin, "An overview of switched capacitor networks," Conf. Record of the fourteenth Asilomar Conf. on circuits, system and computers, Pacific Grove, pp. 10-14, Nov. 1980. (H) 
[22] E.I. EI-Masry, "State space switched capacitor filter structure," fourteenth Asilomar conf. on circuits, system and computers, Pacific Grove, pp. 5-9, Nov. 1980. (D)

[23] M.S. Lee, G.C. Temes, C. Chang and M.B. Ghaderi, "Bilinear switched capacitor ladder filters," fourteenth Asilomar conf. on circuits, system, Computers, Pacific Grove, pp. 435-9, Nov. 1980. (D)

[24] P. Moos, "Switched capacitor circuits for frequency of analogue signals," Sdelovaci. Tech., vol. 28 , no. 12 , pp. 457-8, Dec. 1980. (H)

[25] S.M. Bozic, "Sample data filter with switched capacitor," Int. J. Electron., vol. 47, no. 6, pp. 537-43, Dec. 1980. (D)

[26] E. Luder, "Switched capacitor insensitivity to parasitic," AEU, vol. 34, no. 12, pp. 501-6, Dec. 1980. (D)

1981

[27] J. Szopa and N. Nirt, "Topological analysis of switched capacitor network," Nachrichten. Elektronik, vol. 31, no. 12, pp. 500-4, Jan. 1981. (A)

[28] P. Hudec, "Synthesis of switched capacitor networks," Elektrontech., vol. 32, no. 11 , pp. $838-41,1981$. (A)

[29] P. Lutz, "Sensitivities of impedance scaled SC filters," Electron. Lett., vol. 17, no. 1, pp. 24, Jan. 1981. (D)

[30] D.C. Von Gruenigen, U.W. Brugger and G.S. Moschytz, "Simple switched capacitor decimation circuit," Electron. Lett., vol. 17, no. 1, pp. 30-1, Jan. 1981. (H)

[31] F. Maloberti, F. Montecchi and V. Svelto, "Noise and gain in a SC integrator with real operational amplifier," Altra. Freq., vol. 50, no. 1, pp. 4-11, Feb. 1981. (B)

[32] J.A. Zumbado, "Switched capacitor resonator for an active band pass filter," IBM. Tech. Disclosure. Bull., vol. 23, no. 9, pp. 214-15, Feb. 1981. (D)

[33] F. Ueno and I. Oota, "A new switched-capacitor transform and its application," Trans. Inst. Electron. \& Communi. Engg. Jpn. Sect. E., vol. E64, no. 2, pp. 99, Feb. 1981. (H)

[34] P. Gillingham, "Stray insensitive switched-capacitor biquad with reduced number of capacitors," Electron. Lett., vol. 17, no. 4, pp. 171-3, Feb. 1981. (D)

[35] Hui Zhi kui and Ai. Wang, "A method of computer-aided analysis to SC networks," Shanghai. Jiaotong. Daxue. Xuebao., no. 3, pp. 43-56, March 1981. (A)

[36] V.R. Raschke, "Method and examples for the design of switched-capacitor filters," Frequenz, vol. 35, no. 3-4, pp. 86-9, March 1981. (D)

[37] P. Lutz, "Real terminations of SC filter using LDI integration," Frequenz., vol. 35, no. 3-4, pp. 93-5, March 1981. (D)

[38] A. Knob, "High order switched-capacitor filter synthesis," Mitt. Agen, no. 31, pp. 23-9, March 1981. (D)

[39] R. Inigo and Madrigal, "The switched capacitor filter, a completely integrated analogue filter," Mundo. Electron., no. 105, pp. 115-21, March i981. (D)

[40] F. Anday, "Realization of second order transfer function with switched capacitor networks," Int. J. Electron., vol. 50, no. 9, pp. 169-74, March 1981. (A) 
[41] J. Mikula, "Operational properties of switched capacitor components," Automatic, vol. 24, no. 3, pp. 62-6, March 1981. (H)

[42] I. Cederbaum, "Voltage amplification in switched capacitor networks," Electron. Lett., vol. 17, no. 4, pp. 194-6, March 1981. (B)

[42] T. Inoue and F. Ueno, "New switched capacitor ladder filter with reduced number of amplifiers," Electron. Lett., vol. 17, no. 5, pp. 209-10, March 1981. (D)

[43] J.J. Mulawka, "Switched capacitor analogue delays comprising unity gain buffer," Electron. Lett., vol. 17, no. 7, pp. 275-6, April 1981. (H)

\section{ACKNOWLEDGMENT}

The author is very much grateful to the Director, Delhi Institute of Technology for permitting him to carry research work in this Institute. 

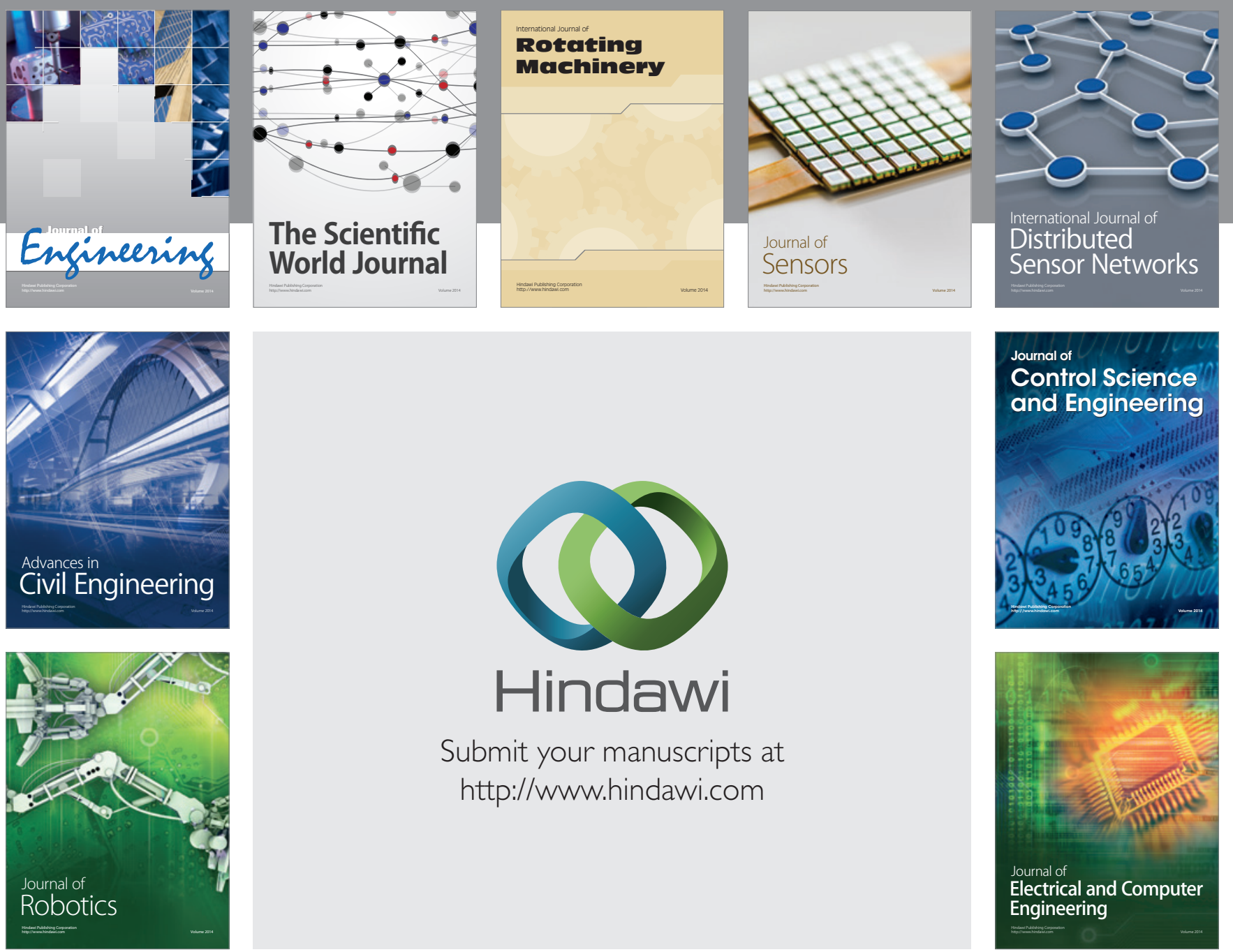

Submit your manuscripts at

http://www.hindawi.com
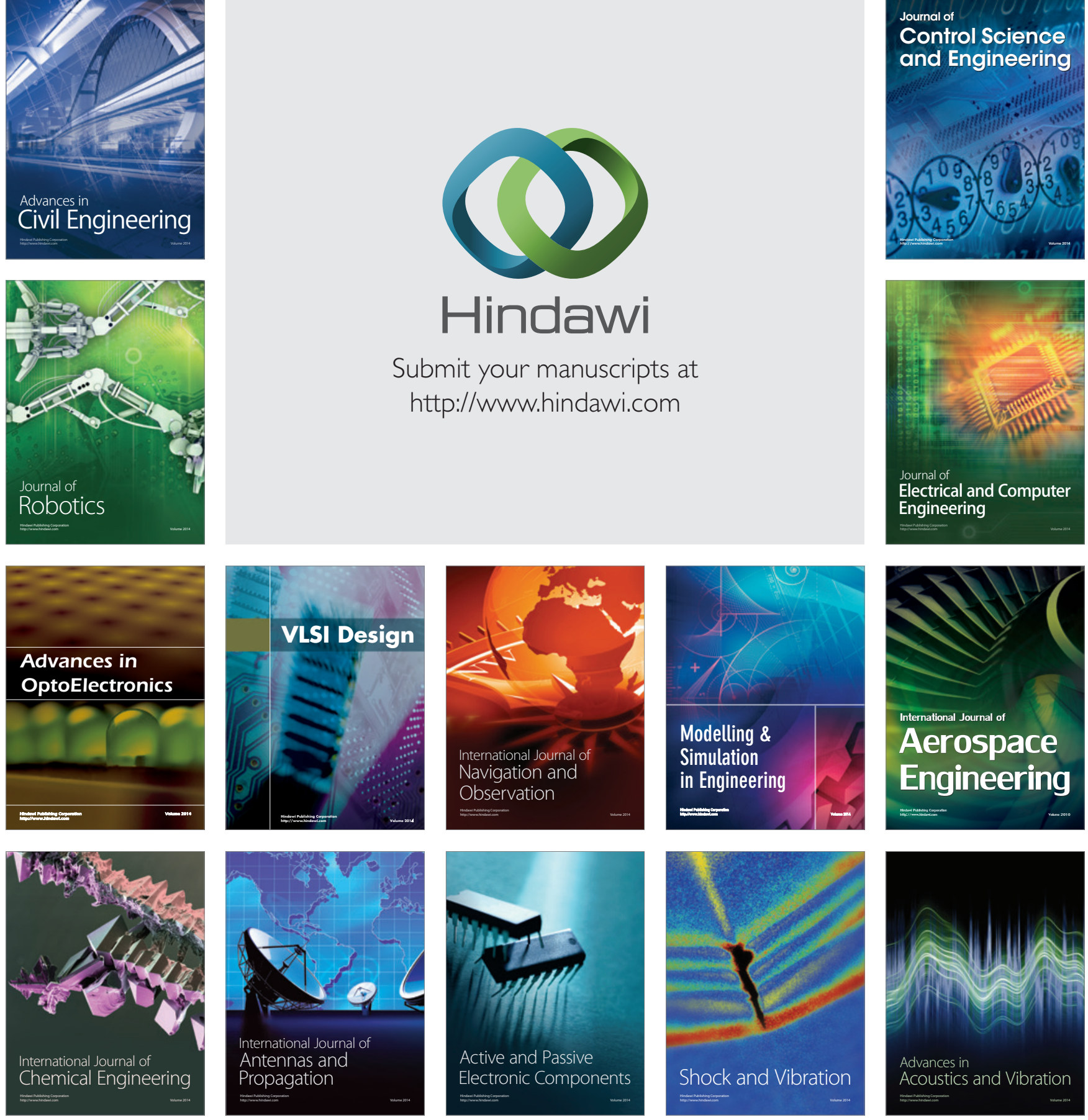